\title{
4. MAGMATIC OXIDES AND SULFIDES IN GABBROIC ROCKS FROM HOLE 735B AND THE LATER DEVELOPMENT OF THE LIQUID LINE OF DESCENT ${ }^{1}$
}

\author{
James H. Natland, ${ }^{2}$ Peter S. Meyer, ${ }^{3}$ Henry J.B. Dick, ${ }^{4}$ and Sherman H. Bloomer ${ }^{5}$
}

\begin{abstract}
Extended high-iron differentiation occurred while the gabbroic rocks of Hole 735B were undergoing intense ductile and brittle deformation beneath a spreading ridge segment near Atlantis II Fracture Zone, Southwest Indian Ridge. Within the partially molten mass, the deformation formed fissures, cracks, and porphyroclastic to gneissic shear zones with fine-scale porosity structure into which dense, iron-rich liquids or crystal mushes could migrate. The iron-rich liquids differentiated from melts squeezed during the deformation from interstitial spaces in adjacent or nearby olivine gabbros and troctolites, most of which retain a porosity of less than $3 \%$, based on low abundances of $\mathrm{TiO}_{2}, \mathrm{P}_{2} \mathrm{O}_{5}$, and $\mathrm{Zr}$. Oxide minerals formed at a very late stage from the squeezed liquids and were left in places as extensive ilmenite-rich concentrates, following compaction of the partially molten surrounding rock and continued filter-pressing of residual liquids. The oxide concentrates contain abundant undeformed globular aggregates of pyrite, pyrrhotite, and chalcopyrite and thus crystallized after most ductile deformation had taken place. Most of the content of potassium, phosphorus, zirconium, and other excluded elements squeezed from the rocks was reincorporated into intruding basalt magmas, producing enhancements of the abundances of these elements in drilled basalts and dredged basalt glasses.

A semiquantitative liquid line of descent has been estimated for $\mathrm{FeO}^{*}, \mathrm{TiO}_{2}, \mathrm{P}_{2} \mathrm{O}_{5}, \mathrm{MnO}$, and sulfur abundances, based on starting glass compositions from basalts dredged from the Atlantis II Fracture Zone and gabbro bulk compositions and mineralogy. Parental melts were sodic and titanium-rich abyssal tholeiites, typical of the region. Four somewhat different parental magma types were involved, based on strontium compositions of the gabbros. These produced variably differentiated gabbros that alternate throughout the section. The oxide gabbros were derived from the two more $\mathrm{Sr}$-rich parental lineages.

Progressive iron enrichment is presumed to have taken place to the point of immiscible separation of siliceous and very iron-rich liquids, as indicated by the mineral data and comparisons to experimental analogs. The siliceous component at Hole 735B is represented by late trondhjemitic dikelets in oxide ferrogabbros, whereas the iron-rich liquids probably were the sources of many of the oxide concentrates. Both silicic and iron-rich segregations locally penetrated porosity space in more primitive crystallizing gabbros, reacting with minerals and intercumulus liquids already present. Liquid density calculations indicate that the iron-rich liquids should have sunk through crystal cumulates until porosity-limiting horizons were reached, whereas the siliceous liquids were buoyant. The iron-rich liquids left from immiscible segregation of trondhjemite had high abundances of sulfur ( $>3000 \mathrm{ppm})$ and $\mathrm{MnO}$ $(>0.6 \%)$, accounting for the consistently high abundances of globular sulfides in the oxide concentrates and the high $\mathrm{MnO}$ contents of ilmenites.

Deformation accelerated subsolidus recrystallization of the gabbro mass and carried it to virtually every rock. Plagioclase, pyroxenes, and oxide minerals consequently have modified compositions. Pyroxene and two-oxide thermometers indicate that the transition between ductile and brittle deformation took place below about $900^{\circ} \mathrm{C}$. Static recrystallization of oxides proceeded in the presence of hydrous fluids until brown amphibole became stable at about $600^{\circ} \mathrm{C}$.
\end{abstract}

\section{INTRODUCTION}

The gabbroic rocks cored at Ocean Drilling Program (ODP) Hole 735B, near Atlantis II Fracture Zone, Southwest Indian Ridge (Fig. 1) include abundant Ti-ferrogabbros, rich in ilmenite and magnetite. Although similar rocks have been dredged from a number of fracture zones, including several in the Indian Ocean (Engel and Fisher, 1975), the drilled section allowed shipboard scientists to discern relationships between these and less-fractionated olivine gabbros and troctolites. The most important observations are (1) that virtually the entire variability in gabbros obtained by dredging from fracture zones is present here, in one short $500.7-\mathrm{m}$ section, and (2) that many of the rocks were

\footnotetext{
${ }^{1}$ Von Herzen, R. P., Robinson, P. T., et al., 1991. Proc. ODP, Sci. Results, 118: College Station, TX (Ocean Drilling Program).

2 Scripps Institution of Oceanography, La Jolla, CA 92093, U.S.A.

${ }^{3}$ Rhode Island College, Providence, RI 02908, U.S.A.

${ }^{4}$ Woods Hole Oceanographic Institution, Woods Hole, MA 02543, U.S.A.

5 Boston University, Boston, MA 02215, U.S.A.
}

variably, but locally intensely, deformed during the later stages of differentiation represented by the crystallization of the oxide-rich ferrogabbros (Robinson, Von Herzen, et al., 1989). More than one-third of the core experienced macroscopically obvious ductile deformation (Dick et al., this volume). Moreover, based on an evaluation of shipboard chemical data in this study, almost all intercumulus liquid was squeezed from the remaining rocks during the same high-temperature deformation process. Virtually no rock in the section cored is an undeformed cumulate.

This chapter presents an evaluation of the liquid line of descent responsible for the gabbros of Hole $735 \mathrm{~B}$ based on three principal data sets: (1) bulk compositions of gabbros presented in Table 4 of the Site 735 report in Robinson, Von Herzen, et al. (1989); (2) compositions of glasses from basalts dredged from Atlantis II Fracture Zone (Dick et al., this volume) plus several basalts drilled during Leg 118, analyzed on board ship; and (3) compositions of ilmenite, magnetite, sulfide minerals, and associated silicates from core samples of Hole $735 \mathrm{~B}$, as measured by electron probe microanalysis. The several data sets have been used to outline the course of 
$\mathrm{N}$

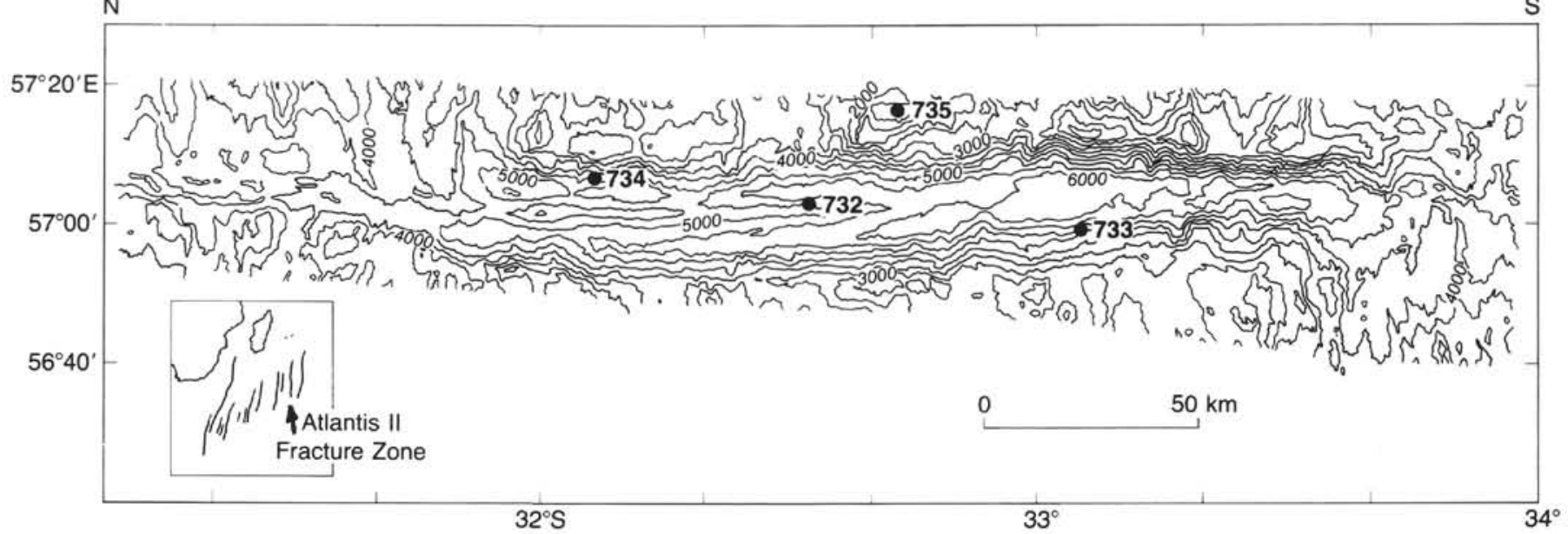

Figure 1. Bathymetric map at 500-m contour intervals of Atlantis II Fracture Zone, Southwest Indian Ridge, showing Leg 118 drill sites. Site 735 is at the top. Survey from Conrad cruise 27-09 (H. Dick, Chief Scientist, with D. Gallo and R. Tyce).

late-stage differentiation and also to establish something of the conditions of deformation and recrystallization of the rocks.

The principal hypothesis we developed is that extended high-iron differentiation took place, leading to segregation of two silicate liquids, one siliceous, the other very iron-rich, after about $90 \%$ of crystallization of parental abyssal-tholeiite magma. Oxide-rich concentrates formed from crystallization of the dense, iron-rich liquids that existed prior to and following immiscible segregation, whereas the siliceous liquids produced trondhjemitic veins and dikelets at various places in the core. Concurrent brittle/ductile deformation allowed for partial redistribution of the iron-rich liquids or partially crystalline oxide concentrates along fractures and shear zones, reaching into previously crystallized olivine gabbros and troctolites tens to hundreds of meters away.

\section{METHODS}

Procedures for shipboard X-ray fluorescence chemical analyses, together with information about analytical precision, are given in the "Introduction" in Robinson, Von Herzen, et al. (1989). More than 90 gabbroic rocks, a diabase, and a trondhjemite were analyzed from Hole 735B. Major oxides and trace elements were determined on all samples but the trondhjemite, for which only major oxides were determined. Several other basalts were analyzed from Sites 732 and 734. Preliminary interpretations written on board ship are in the site reports.

Glass rims to pillow basalts obtained during the pre-drilling survey (Dick et al., this volume) were analyzed by electron probe. Conditions of analyses were as in Natland and Melson (1980), except that they were determined at Scripps Institution using a three-channel wavelength-detecting automated CAMEBAX microprobe. All analyses have been reported as fivespot averages that were normalized to USNM basalt glass standard VG-2. The standard itself was analyzed at five spots before and after every pair of unknowns, and the unknowns were normalized to the averages of all ten spots on the standard. Separate, high-precision determinations were made for $\mathrm{K}_{2} \mathrm{O}, \mathrm{P}_{2} \mathrm{O}_{5}$, and $\mathrm{S}$, using a defocused beam, 20-Na beam current, and a total of 6 min of counting on four separate spots per glass, with $6 \mathrm{~min}$ apiece on high and low background. Abundances of $\mathrm{K}_{2} \mathrm{O}$ and $\mathrm{P}_{2} \mathrm{O}_{5}$ were calibrated to a range of values for basalt glasses determined by $\mathrm{DC}$ plasma procedures at Lamont-Doherty Geological Observatory. Sulfur was calibrated using mineral standards (USNM apatite and scapolite;
Jarosewicz et al., 1979; pure barite). A small matrix correction was applied based on differences in bulk mass absorption coefficients calculated from bulk mineral and glass compositions (following the XMAT procedure for X-ray fluorescence analysis of Bougault et al., 1977).

\section{DATA EVALUATION}

In this report, we integrate three large analytical data sets (shipboard XRF analyses, glass compositions, and mineral compositions) with the lithostratigraphy of Hole $735 \mathrm{~B}$ and petrographic information. Moreover, the petrogenesis of gabbros from Hole 735B bears on several aspects of tholeiitic differentiation in the ocean crust itself and in layered igneous intrusions, which require appropriate comparisons. The comparisons are mainly provided in the figures, but are discussed sequentially in the text with the data presentation, rather than in a separate interpretive section requiring reference to figures already cited some pages previously. Principal comparisons are to the Skaergaard layered igneous intrusion and to Indian Ocean basalt glasses and gabbros from dredge collections.

Apart from this, the chapter is organized so as to consider shipboard data first (structural setting of the site, lithostratigraphy, chemical stratigraphy), then glass compositions, and finally mineral data (silicates, oxides, and sulfides) before a general interpretation is offered. However, evaluation of the shipboard chemical data will include partially interpretive subsections that deal with estimates of residual melt porosities, the general course of the liquid line of descent, and the diversity of parental magma compositions, as they can be inferred simply from gabbro compositions. These will follow the subsection on chemical stratigraphy, inasmuch as they provide essential background for most of what follows.

\section{SETTING}

Hole $735 \mathrm{~B}$ was drilled in $700 \mathrm{~m}$ of water atop the flat, erosionally beveled summit of the eastern transverse ridge of Atlantis II Fracture Zone on the Southwest Indian Ridge, about $18 \mathrm{~km}$ from the trace of the active transform fault (Fig. 1). Dick et al. (this volume) provide a general tectonic interpretation of the fracture zone, based on the pre-drilling survey and on interpretation of the structure and magnetic results of the rocks cored at Hole 735B. The gabbros crystallized about $10 \mathrm{~m} . \mathrm{y}$. ago beneath the floor of the rift-valley segment lying north of the site. There, the rocks were deformed, magnetized as a result of metamorphic processes, 


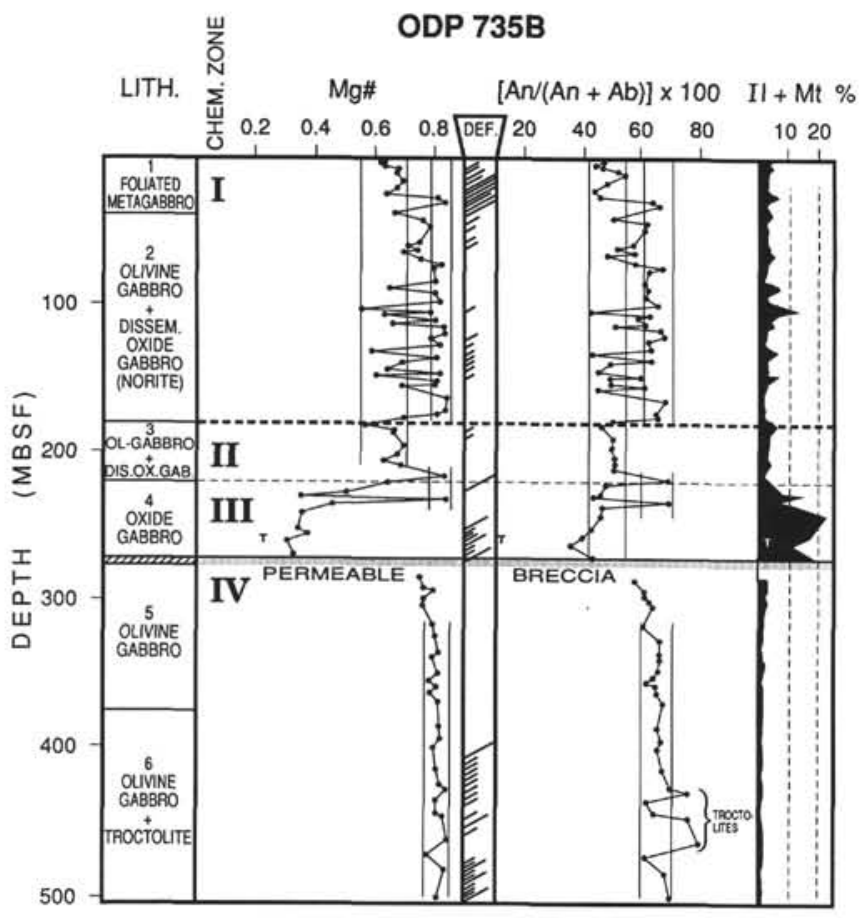

Figure 2. Summary stratigraphy and downhole chemical variations at Hole 735B, Southwest Indian Ridge. Parameters plotted from left to right are $\mathrm{Mg} \#\left(=\mathrm{Mg} /\left[\mathrm{Mg}+\mathrm{Fe}^{2+}\right]\right.$, where $\mathrm{Fe}^{2+} /\left[\mathrm{Fe}^{2+}+\mathrm{Fe}^{3+}\right]=$ 0.86 ); generalized extent of deformation (degree given by length of diagonals); normative $\mathrm{An} /(\mathrm{An}+\mathrm{Ab})$; and normative ilmenite plus magnetite. Chemical parameters are calculated from analyses in the Site 735 report (Robinson, Von Herzen, et al., 1989), based on shipboard XRF determinations by R. Emmerman, J. Hertogen, and W. Autio.

unroofed, and quickly ramped upward to the crest of the transverse ridge near the ridge-transform intersection, where the rocks breached sea level. Elsewhere in the Indian Ocean, Anna de Koenig Seamount near DuToit Fracture Zone $\left(52^{\circ} \mathrm{S}\right)$ and Melville Bank near Melville Fracture Zone $\left(18^{\circ} \mathrm{S}\right)$ are in precisely analogous locations now, and plutonic rocks have been dredged from shallow depths on both (Engel and Fisher, 1975; Fisher et al., 1986).

The causes of the unroofing and uplift of these events are conjectural, but at Site 735 , the rocks drilled retain a structural imprint (orientation of deformation fabric) and magnetic inclinations clearly related to high-angle listric faulting in the rift valley, rather than transform shear. Following erosional truncation, $700 \mathrm{~m}$ of simple subsidence occurred. The same general history probably applies to other transverse ridges where plutonic rocks are so commonly accessible to the dredge.

The late-stage differentiation processes discussed here, and the partly concurrent deformation of the rocks, therefore took place at a spreading ridge. No place other than the rift valley was hot enough, nor was it subject to the type of deformation seen in the rocks.

\section{EVALUATION OF SHIPBOARD RESULTS}

\section{Lithological and Petrological Summary}

A summary of the lithologies and rock compositions encountered sequentially in Hole $735 \mathrm{~B}$ is presented in Figure 2. The several lithological units indicated in the left column and the locations of the most obvious zones of porphyroclastic/ gneissic deformation are based on shipboard and post-cruise descriptions (Dick et al., this volume). The chemical parameters plotted vs. depth are $\mathrm{Mg} \#\left(=\mathrm{Mg} /\left[\mathrm{Mg}+\mathrm{Fe}^{2+}\right]\right)$, normative $A n /(A n+A b)$, and the sum of normative ilmenite plus magnetite, calculated from shipboard X-ray fluorescence analyses in the Site 735 chapter (Robinson, Von Herzen, et al., 1989). $\mathrm{Mg} \#$ and the percentage of normative magnetite were calculated assuming $\mathrm{Fe}^{2+} /\left(\mathrm{Fe}^{2+}+\mathrm{Fe}^{3+}\right)=0.86$, a common assumption for basalts (e.g., Presnall et al., 1979), but not well known for gabbros. The average $\mathrm{Fe}^{2+} /\left(\mathrm{Fe}^{2+}+\mathrm{Fe}^{3+}\right)$ for 95 gabbros analyzed from Hole $735 \mathrm{~B}$, as listed in the site reports, is $0.90 \pm 0.05$, but this value is slightly lower for nine Tiferrogabbros $(0.83 \pm 0.06)$ and higher for 39 olivine gabbros and troctolites $(0.94 \pm 0.04)$ in the lower $230 \mathrm{~m}$ of the hole. The ratio clearly has been influenced by alteration, but the consistently high values indicate that alteration was non-oxidative in character, in accord with visual and thin-section observations summarized in the site report. Indeed, compositions of oxide minerals given below suggest that the oxidation state of the rocks may actually have been reduced during subsolidus recrystallization of the rocks. The choice of an arbitrary single value for the normative computations in general permits them to reflect more closely and consistently the primary mineralogy of the rocks.

$\mathrm{Mg} \#$ and normative $\mathrm{An} /(\mathrm{An}+\mathrm{Ab})$ are effectively "cryptic" parameters that reflect the average compositions of ferromagnesian silicates and feldspars, respectively, rather than gravitationally or chemically accentuated concentrations of minerals in cumulates. The samples chosen for shipboard $\mathrm{XRF}$ analyses were selected on the basis of freshness, and to represent the cores. Thus, amphibolized and albitized rock in breccias or near fractures was avoided. Toward the bottom of the hole, some narrow intervals rich in $\mathrm{Fe}$ - Ti oxides also were not sampled because they were exceptional, and time at the end of the leg was short.

The rocks of Hole 735B can be divided into four zones, or chemical units, based on the shipboard analyses. These correlate generally with the lithologic units given in Dick et al. (this volume) as follows. Zone I combines lithologic Units I (deformed gabbronorite plus mixed gabbronorite and olivine gabbro) and II (olivine gabbro with intervals of oxide gabbro). This zone consists of moderately iron-rich $(\mathrm{Mg} \#=0.5-0.7)$ and moderately albitic gabbros that alternate regularly with more magnesian (Mg\#s $>0.8$ ) and anorthitic gabbros. Zone II corresponds to lithologic Unit III, in which disseminated oxide olivine gabbros (with about $1 \% \mathrm{Fe}$-Ti oxides) and olivine gabbros alternate with oxide gabbros (defined as having $>5 \% \mathrm{Fe}-\mathrm{Ti}$ oxides). Chemical analyses through this interval are persistently iron-rich and sodic, similar to the more fractionated rocks of Zone I.

Zone III coincides with the massive oxide gabbros of lithologic Unit IV. These rocks are iron-rich and systematically have more than $10 \% \mathrm{Il}+\mathrm{Mt}$ in the norms, and in Core 118-735B-53R, there are a number of prominent trondhjemitic dikelets and veins crosscutting foliated rock. Additional small felsic and trondhjemitic veinlets occur elsewhere in the core (Dick et al., this volume). The base of this lithologic unit is just above a hydrothermally altered, permeable breccia at 277 mbsf (Dick et al., this volume; Becker, this volume). The breccia zone is actually within the next lower lithologic unit and is near, but not precisely at, the boundary with the oxide gabbros of Zone III (lithologic Unit IV).

Zone IV combines lithologic Units V and VI, which consist of monotonous olivine gabbros with more magnesian troctolites toward the bottom of the hole. The analyzed troctolites are anorthitic. Lithologic Unit VI, which extends to the 
bottom of the hole, also contains intervals of oxide gabbro and olivine gabbros with disseminated oxide that were not analyzed on board the ship (but see Dick et al., this volume, for analyses of these rocks). This unit actually comprises a fifth chemical zone in which rocks having compositions as diverse as troctolite and Ti-ferrogabbro alternate in the core.

The stratigraphic variations in $\mathrm{Mg \#}$ and normative $\mathrm{An} /(\mathrm{An}$ $+\mathrm{Ab})$ are highlighted in Figure 2 in such a way as to show that rock compositions are effectively bimodal, being olivine gabbros plus troctolites on one hand, and disseminated oxide olivine gabbros and massive oxide gabbros on the other. All intervals consist at least in part of the first group, and these rocks have consistent compositions in terms of "cryptic" parameters. The other group has distinctly lower $\mathrm{Mg \# s}$ and normative $\mathrm{An} /(\mathrm{An}+\mathrm{Ab})$ ratios, but spans a considerable range in composition. The most evolved gabbros are the oxide-rich rocks of Zone IV, which have the lowest An ratios and markedly lower $\mathrm{Mg \# s}$ because of their abundant oxides. For these rocks, $\mathrm{Mg \# s}$ are not simply a representation of the compositions of bulk ferromagnesian silicates.

The abrupt juxtapositions of lithologies, especially in Zone II and near the bottom of the hole, are illustrated well by the downhole log of magnetic susceptibility (Fig. 3), which was especially sensitive to the presence of concentrations of oxide minerals in the wall of the hole. The massive oxide gabbros show up distinctly, but clearly there are many short intervals that contain oxide minerals abruptly juxtaposed with olivine gabbros (having low magnetic susceptibility) up and down the hole. Only an interval about $120 \mathrm{~m}$ thick just below the breccia at the top of Zone IV appears to be free of oxide gabbros.

Four intervals of most prominent porphyroclastic/gneissic deformation are also indicated in Figure 3. Three of the four correspond closely to occurrences of oxide-bearing or oxiderich gabbros. The deformed rocks of lithologic Unit I exhibit weak magnetic susceptibility because this is one interval that has pronounced oxidative alteration, in which magnetite was largely transformed to other minerals.

Neither chemical analyses nor the magnetic susceptibility log accurately define how abrupt the lithologic transitions really are. A thin section of a rock near the base of Unit II, at 164 mbsf (118-735B-35R-1, 49-54 cm) shows a sharp contact (Fig. 4), which indicates that the oxide-bearing gabbro intruded olivine gabbro. The two parts of the thin section are almost equivalently coarse-grained, but the broken grains of the olivine gabbro at the contact establish the relationship.

Similar sharp contacts between olivine gabbro and oxidebearing gabbro, between troctolite and olivine gabbro, and between strongly and weakly deformed gabbro, are described by Dick et al. (this volume). However, in deformed zones, possible intrusive relationships are obscured by cataclasis and the consequences of ductile flow. Nevertheless, with the exception of the massive oxide gabbro (lithologic Unit IV), oxide-bearing gabbros are structurally juxtaposed with more primitive gabbros at abrupt contacts, suggesting a generally intrusive relationship. In some cases, these juxtapositions may have been produced by ductile deformation. Thus, these rocks do not represent rhythmic cumulates crystallized in a repetitively replenished magma chamber.

\section{Co-Variation of $\mathbf{M g \#}$ and Normative $\mathrm{An} /(\mathbf{A n}+\mathbf{A b})$}

Figure 5 depicts the co-variation of "cryptic" parameters $\mathrm{Mg} \#$ and normative $\mathrm{An} /(\mathrm{An}+\mathrm{Ab})$ for Hole 735B gabbros and compares them with other gabbro suites from the Indian Ocean and Skaergaard Intrusion. The diagram is similar to one used by Wager (1960) and Wager and Brown (1967) in which "iron ratios" were plotted vs. "albite" ratios for the Skaer-

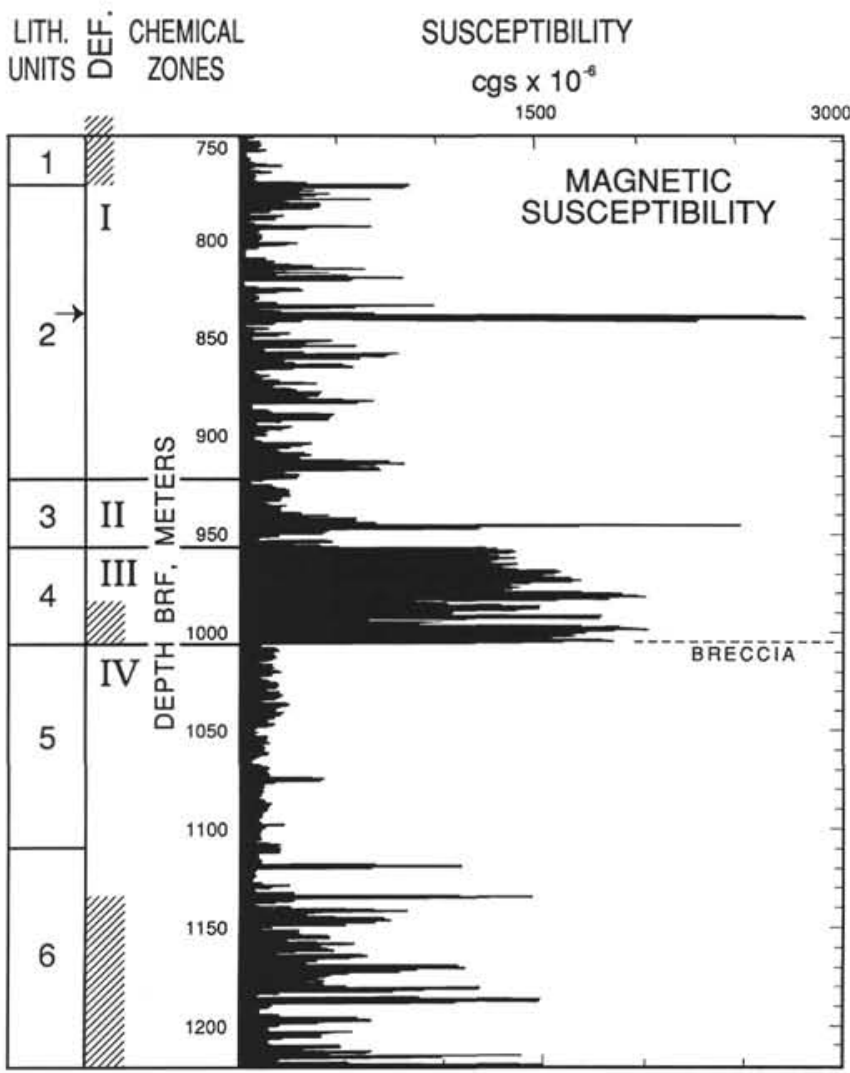

Figure 3. Downhole log of magnetic susceptibility (cgs X 10-6), made with the USGS susceptibility tool. No smoothing applied. Left columns identify corresponding lithologic units, chemical zones, and zones of most intense deformation in the hole.

gaard Intrusion. However, because $\mathrm{Mg \#}$ is commonly used as an index of differentiation for abyssal tholeiites and can be related simply to mineral compositions (e.g., olivine; Roeder and Emslie, 1970), Figure 5 shows differentiation sequences in terms of $\mathrm{Mg \# s}$ and normative $\mathrm{An} /(\mathrm{An}+\mathrm{Ab})$, which are effectively reciprocals of "iron" and "albite" ratios as used by Wager and Brown.

Compositions of samples from Zones I through III that were analyzed on board ship are plotted in Figure 5A; those from Zone IV are plotted in Figure 5B. In both diagrams, a tight clustering of points can be seen to correspond to olivine gabbros and troctolites near or above $\mathrm{Mg} \#=0.8$. There is no substantive difference in the "cryptic" compositions of these rocks above and below the Zone III/Zone IV boundary.

Disseminated-oxide gabbros fall in a separate region, below the olivine gabbros and to their left in Figure 5A. Oxide-rich gabbros of lithologic Unit IV are similarly albitic, but have lower Mg\#s. The most evolved rock, the trondhjemite, plots at least $\mathrm{Mg} \#$ and normative $\mathrm{An} /(\mathrm{An}+\mathrm{Ab})$, at the lower left.

Gabbros dredged from Indian Ocean fracture zones (Engel and Fisher, 1975) exhibit a similar range of compositions, but are displaced to the right of the Hole 735B analyses in Figure

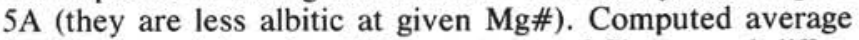
liquid compositions for different stages of Skaergaard differentiation (Wager and Brown, 1967) are shown in both halves of the figure, and the individual Skaergaard samples in Figure 5B. The computed liquid compositions for Skaergaard plot close to locations of corresponding groups of gabbro analyses 


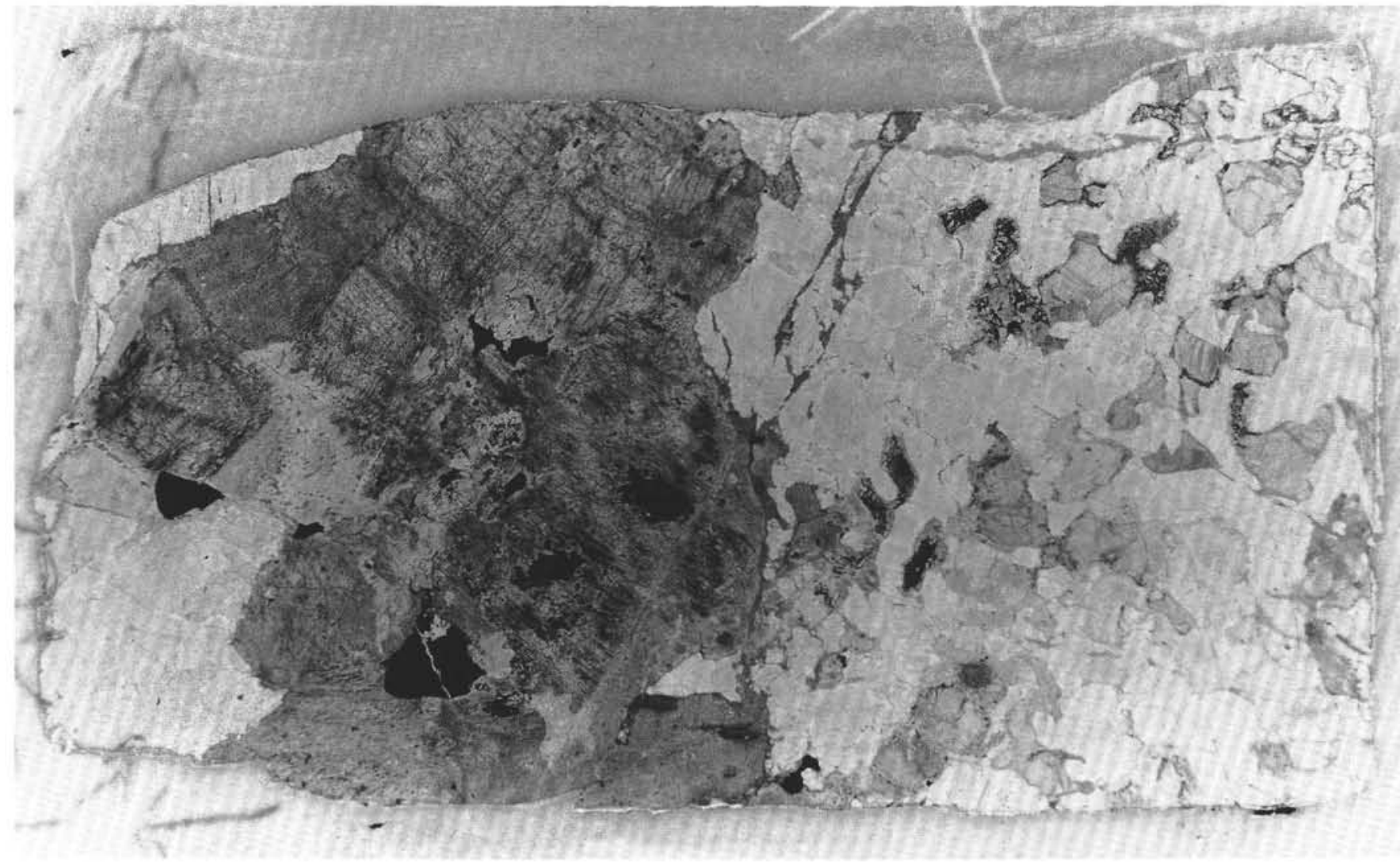

Figure 4. Full thin-section photomicrograph of Sample 118-735B-35R-1, 49-54 cm, showing a sharp contact between oxide-bearing gabbro (right) and olivine gabbro (left).

from various parts of the Layered Series and Marginal Border Groups (Wager and Brown, 1967).

The gabbros from Hole $735 \mathrm{~B}$ thus span the compositional range of gabbroic intrusives sampled thus far from the Indian Ocean, as well as most of the rocks from the Skaergaard Intrusion. In fact, the troctolites evidently crystallized from liquids more primitive than those that produced the quenched marginal gabbros of Skaergaard, which Hoover (1989) reported as ferrobasaltic in composition. At the other extreme, the trondhjemite is similar to the two compositions reported for Skaergaard's Tinden granophyre by Wager and Brown (1967). An important contrast to Skaergaard is the absence at Hole $735 \mathrm{~B}$ of iron-rich plutonic rocks that correspond to Upper Zone C and Upper Border Group and siliceous melanogranophyres of the Skaergaard. Apart from the trondhjemite, no siliceous rocks came from Hole 735B. None of the gabbros has more than $54 \% \mathrm{SiO}_{2}$.

\section{Residual Melt Porosities}

Gabbroic rocks usually consist of cumulus crystals that were concentrated by some means on the floor, walls, or roof of a magma body and a certain percentage of minerals crystallized from melt trapped between cumulus minerals. Petrologists often distinguish the original amount of intercumulus liquid, given the dimensions and packing arrangement of cumulus minerals, from what remains after all compaction and fluid exchange with the magma body ceased. Procedures for determining the percentage and composition of the final interstitial melt are based on combinations of modal analyses, bulk densities, and whole-rock plus mineral compositions (Morse, 1979a; Meyer et al, 1989; Chalokwu and Grant, 1990;
Miller and Weiblen, 1990). The percentage of final interstitial melt is the residual melt porosity.

The gabbros of Hole 735B have extremely low abundances of $\mathrm{P}\left(\right.$ as $\left.\mathrm{P}_{2} \mathrm{O}_{5}\right)$ and $\mathrm{Zr}$, elements that are largely excluded from the most abundant minerals in the rocks (plagioclase, pyroxenes, olivine, oxides), but that might be retained in minerals crystallized from final trapped interstitial melt. However, in many of the rocks, $\mathrm{P}_{2} \mathrm{O}_{5}$ abundances actually are below detection limits $(<0.01 \%)$, suggesting that essentially there is no interstitial material in them. Nevertheless, there is still some $\mathrm{Zr}$ that was measured to higher precision in all the rocks. Thus, whereas the abundances of $\mathrm{P}$ and $\mathrm{Zr}$ and the ratio $\mathrm{P} / \mathrm{Zr}$ should primarily reflect the compositions of final trapped melts; here, the abundances are so low that there may be little or no trapped melt retained in the rocks. In this case, $\mathrm{P}_{2} \mathrm{O}_{5}$ and $\mathrm{Zr}$ give somewhat contradictory indications of how much (or how little) trapped melt might remain.

Two possibilities exist: first, that alteration may selectively have removed $\mathrm{P}$ with respect to the high-field-strength element, $\mathrm{Zr}$; second, that abundances of both elements have provided the same information about residual porosities, but that much of the measured $\mathrm{Zr}$ may simply be tied up in cumulus clinopyroxene for which $\mathrm{Zr}$ has a low, but still significant, melt/crystal partition coefficient $(\mathrm{D}=0.20$; Johnson et al., 1989). Because neither element is particularly mobile during alteration, and there is no petrographic or isotopic evidence for alteration at high water/rock ratios (Kempton et al., this volume; Stakes et al., this volume), the first alternative seems unlikely. Confirmation of the second possibility requires a procedure for estimating both the $\mathrm{Zr}$ contents and abundance of clinopyroxenes in the rocks and 


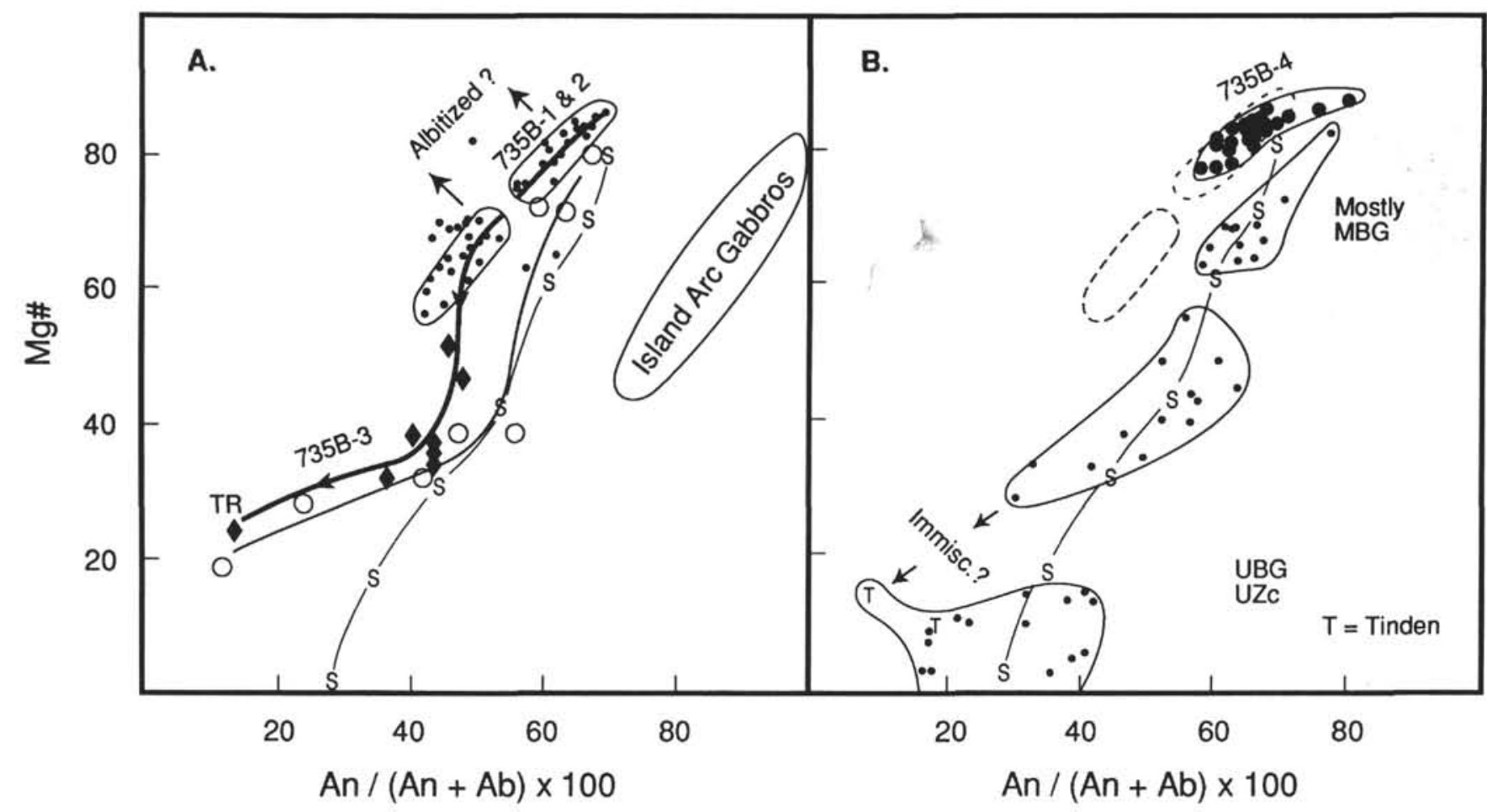

Figure 5. Normative An/(An + Ab) X 100 vs. Mg\# for analyses of gabbroic rocks from Hole 735B (from Site 735 report in Robinson, Von Herzen, et al., 1989). A. The two fields with small dots correspond to chemical Zones 1 and 2 discussed in the text. Diamonds $=$ Ti-ferrogabbros from Zone 3, except TR, the trondhjemite. Open circles = analyses for gabbros from the Central Indian Ridge (Engel and Fisher, 1975), linked by the dashed line. Ss = calculated liquid compositions for various stages of the Skaergaard Intrusion (from Wager and Brown, 1967). B. Analyses for Hole 735B, chemical Zone 4, are shown and compared with actual analyses from Skaergaard, together with the trend of estimated liquid compositions. A possible immiscible relationship for Tinden granopyhre is also indicated. Skaergaard stratigraphy: MBG = Marginal Border Group; UBG = Upper Border Group; $\mathrm{MZ}=$ Middle Zone; UZ = Upper Zone, whether a, b, or c.

then comparing "excess" $\mathrm{Zr}$ (which can be assigned to minerals formed from trapped interstitial liquids) to $\mathrm{P}_{2} \mathrm{O}_{5}$ abundances.

The procedure we developed is given in Appendix A. Briefly, abundances of clinopyroxene in all except the oxide gabbros are assumed to be specified by $\mathrm{TiO}_{2}$ contents, which can be variably diluted primarily by cumulus plagioclase in most samples, plus some olivine and orthopyroxene, which contain virtually no $\mathrm{TiO}_{2}$. If we assume that, to a first approximation, the $\mathrm{Mg} \#$ of the rocks is the same as that of the most abundant ferromagnesian silicate, namely clinopyroxene, then $\mathrm{Fe}-\mathrm{Mg}$ partitioning can be used to establish the $\mathrm{Mg} \#$ of the average liquid that produced the gabbro. Further, we assume that $\mathrm{Mg}$ \#s of trapped melts are the same as those that produced the clinopyroxenes. This assumption is probably debatable, but is the case for residual liquid compositions calculated for other gabbros from the Southwest Indian Ridge using least-squares procedures (Meyer et al., 1989). This assumption is conservative in the sense that the likely $\mathrm{Mg \# s}$ for residual melts were no greater than those that produced average clinopyroxene. Should $\mathrm{Mg \# s}$ in residual melts be lower, the result is residual porosity estimates even less than the values calculated here.

Using glass and aphyric basalt compositions from the region, co-variation of abundances of $\mathrm{TiO}_{2}, \mathrm{P}_{2} \mathrm{O}_{5}$, and $\mathrm{Zr}$ with liquid $\mathrm{Mg \# s}$ can be established. From these and by using melt-crystal partition coefficients $(D)$, concentrations of $\mathrm{TiO}_{2}$ and $\mathrm{Zr}$ in clinopyroxenes then can be predicted. The extent of dilution of clinopyroxene by non-Ti cumulus minerals is given by the proportion of $\mathrm{TiO}_{2}$ in the rock to that calculated for the liquid from which the pyroxenes crystallized. $\mathrm{Zr}$ in clinopyroxene will be diluted by the same extent; thus, the difference between diluted $\mathrm{Zr}$ in clinopyroxene and actual $\mathrm{Zr}$ should be what was retained in the final interstitial melt. This "excess" $\mathrm{Zr}$, divided by the $\mathrm{Zr}$ content estimated for the liquid, gives the fractional porosity.

In general, estimates based on both $\mathrm{Zr}$ and $\mathrm{P}_{2} \mathrm{O}_{5}$ are consistent. That is, because "excess" $\mathrm{Zr}$ is a more precise measure of residual porosity, its value can be used to backcalculate to an expected $\mathrm{P}_{2} \mathrm{O}_{5}$ contents. Differences between expected and measured $\mathrm{P}_{2} \mathrm{O}_{5}$ contents were less than $0.02 \%$ (twice the analytical precision) for all but 10 samples of olivine gabbro and troctolite, with porosities ranging from $0 \%$ to $52 \%$. Six samples gave slightly discrepant results, and four others are greatly discrepant, probably because they contain discrete crystals of zircon or apatite, or may have interacted with high- $\mathrm{Zr}$, low-P trondhjemitic liquids. For oxide gabbros having more than $1 \% \mathrm{TiO}_{2}$, much of it not in clinopyroxene, $\mathrm{P}_{2} \mathrm{O}_{5}$ rather than $\mathrm{Zr}$ was used to estimate porosities.

The actual clinopyroxene/melt $D$ for $\mathrm{Zr}$ proved to be somewhat lower than the value given by Johnson et al. (1989), which gave negative porosities for some samples. Thus, a value was chosen $(0.14$ rather than 0.20$)$ that was consistent with most of the rocks having a porosity of zero or greater. For four troctolites, melt $\mathrm{Mg} \#$ was estimated by assuming that the whole-rock Mg\# was that of olivine. But "excess" $\mathrm{Zr}$ and porosity were then calculated by assuming that all $\mathrm{TiO}_{2}$ in the troctolites is in the small amounts of intercumulus clinopyroxene observed in thin sections (see "Site 735" chapter in Robinson, Von Herzen, et al., 1989). 
Results are presented as histograms in Figure 6. Except for three aberrant samples (with $27.9 \%, 28.7 \%$, and $52.3 \%$, as estimated porosities), Hole 735B gabbros give residual melt porosities of less than $14 \%$ (Fig. 6A), with an average excluding the three samples of $2.5 \%$ and including them of $3.6 \%$. More than one-half of the rocks have residual porosities of less than $2 \%$, which corresponds to the detection limit for $\mathrm{P}_{2} \mathrm{O}_{5}(0.01 \%)$. But using "excess" $\mathrm{Zr}$, such low porosities can be specified to within about $\pm 0.3 \%$, depending on $\mathrm{Mg} \#$ of the sample, based on the precision of $\mathrm{Zr}$ measurements. On this basis, 18 samples have no resolvable $(<0.6 \%)$ residual liquid porosities at all.

Fewer than $20 \%$ of the rocks have porosities between $6 \%$ and $14 \%$. Most rocks with $>4 \%$ porosities occur in the upper two lithologic units (Figs. 6B and 7), whereas only four such rocks occur in lithologic Units V and VI (Figs. 6C and 7), representing $227 \mathrm{~m}(45.3 \%)$ of the cored section. For the higher-porosity rocks, there is no correlation between calculated residual porosity and extent of differentiation as given by $\mathrm{Mg}$ \# (Fig. 7). Instead, there is a clear connection between residual porosity and state of deformation of the rocks. All of the higher-porosity rocks, including the three aberrant samples with $>25 \%$ residual porosity, have porphyroclastic, gneissic, or mylonitic textures. Seven of the eight samples having highest calculated residual melt porosities $(7.7 \%-52 \%)$

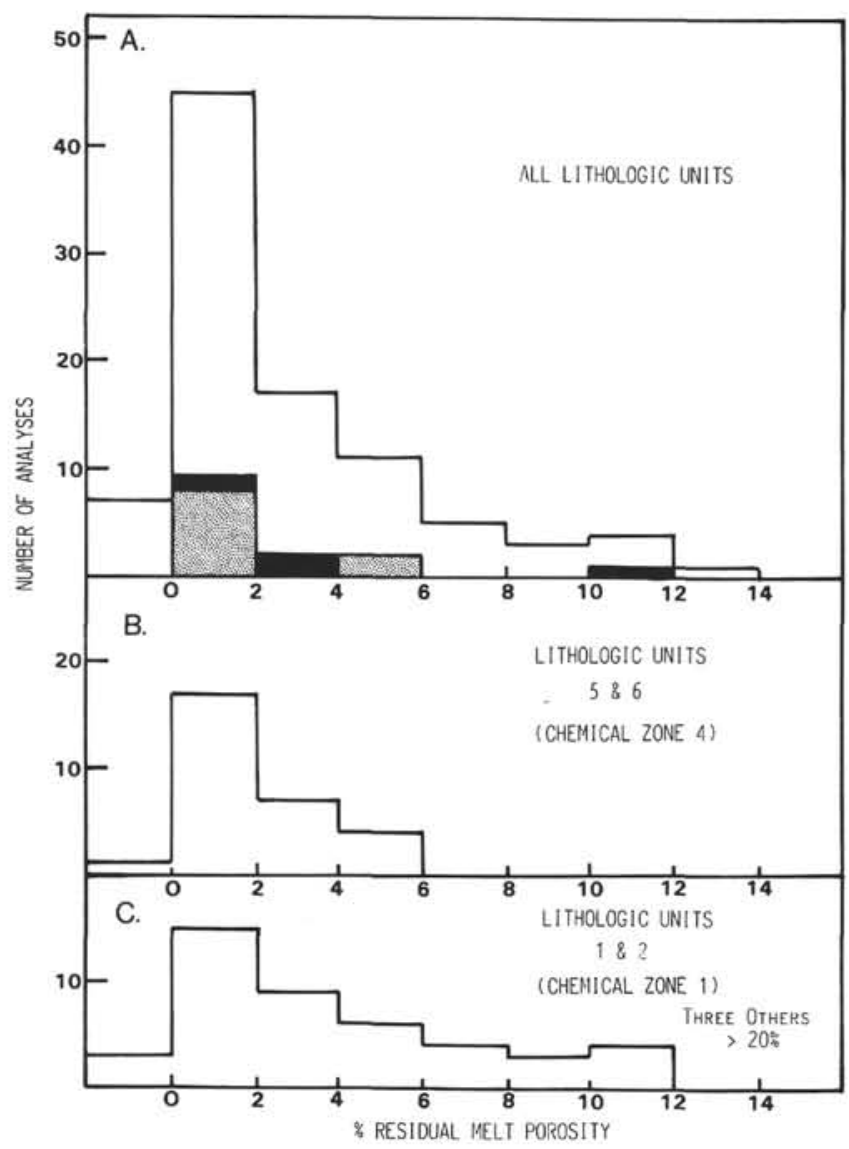

Figure 6. Histograms of residual melt porosities, calculated by the "excess" $-\mathrm{Zr}$ technique (unshaded) and using $\mathrm{P}_{2} \mathrm{O}_{5}$ abundances (shaded $=$ oxide gabbros; diagonally lined $=$ olivine gabbros with anomalous $\mathrm{Zr}$ ) as described in Appendix A. A. All lithologic units. B. Lithologic Units V and VI (chemical Zone 4); C. Lithologic Units I and II. Three samples having high calculated residual porosities are not included.

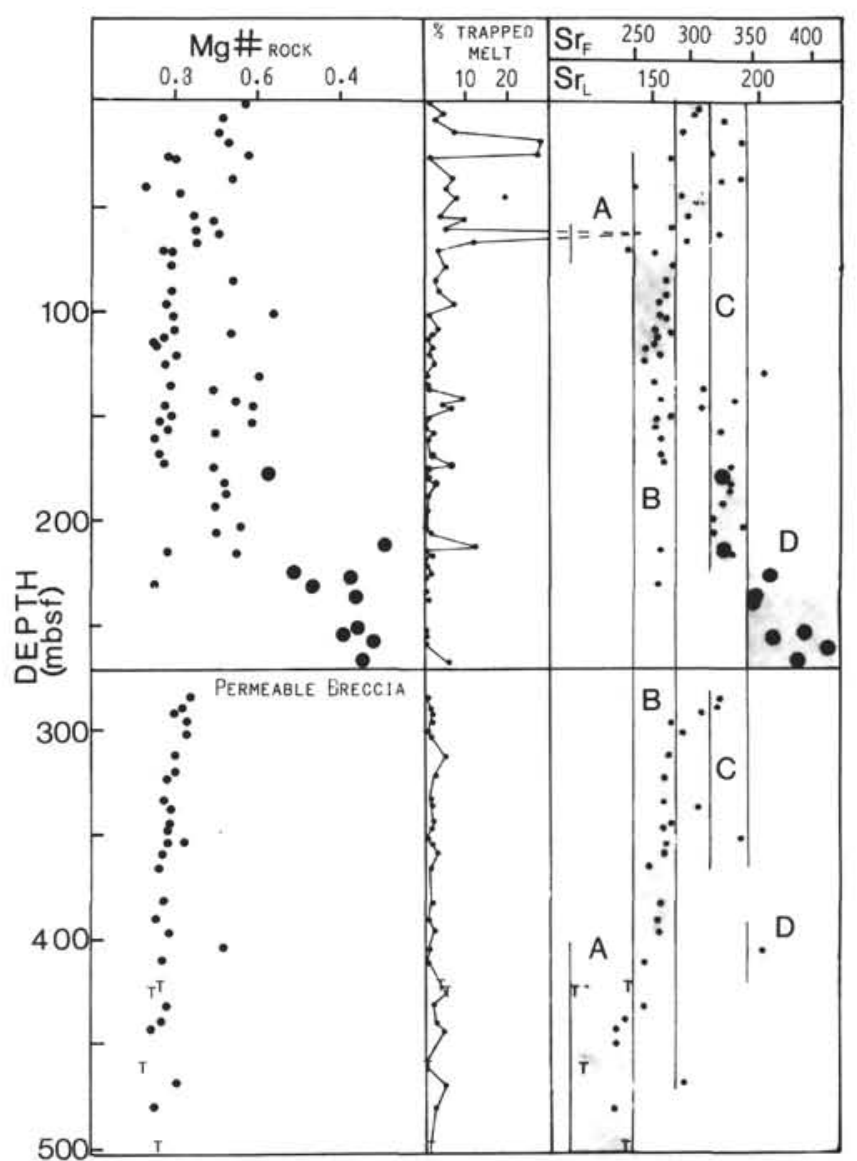

Figure 7. Comparison of calculated residual melt porosity (\% trapped liquid), $\mathrm{Sr}$ in plagioclase $\left(\mathrm{Sr}_{\mathrm{F}}\right)$, and $\mathrm{Mg \# s}$ of gabbros vs. depth below the seafloor in Hole 735B. A separate scale for $\mathrm{Sr}$ in liquids $\left(\mathrm{Sr}_{\mathrm{L}}\right)$ is also shown. See text for distinctions between columns A through D.

occur in the highly deformed upper $70 \mathrm{~m}$ of the hole (Fig. 7). Three of these are adjacent analyzed samples (in Cores 118-735B-4D through -6D, 19-26 mbsf).

Most of the residual porosities calculated are low by any standard. In Figure 8 results from Hole 735B are compared; these have been averaged for intervals of $0.1 \mathrm{Mg}$ \# variation, with porosities calculated by the same procedures for average compositions of different portions of the Skaergaard Intrusion (McBirney, 1989), with $\mathrm{Zr}$ and $\mathrm{TiO}_{2}$ co-variation with liquid $\mathrm{Mg} \# \mathrm{~s}$ established using data on chilled border rocks of Hoover (1989). Also shown are data points for individual gabbros from elsewhere on the Southwest Indian Ridge (Meyer et al., 1989), but calculated using $\mathrm{P}_{2} \mathrm{O}_{5}$ because no $\mathrm{Zr}$ values were given for those samples. However, the porosities estimated using $\mathrm{P}_{2} \mathrm{O}_{5}$ are, within analytical precision, the same as those estimated using bulk compositions, mineral data, and least-squares regressions by Meyer et al. (1989).

The Skaergaard Intrusion exhibits a contrast between rocks of the Layered Zone and Marginal Border Series (MBS) with those of the Upper Border Series (UBS). In part, this is a consequence of differences in liquid compositions from which the UBS and LZ crystallized (Naslund, 1984), but it also may be a consequence of the difference in compaction between roof rocks and cumulates on the floor of the crystallizing intrusion. Morse (1979b) attributes the generally lower residual porosities $(13 \%-3 \%)$ he calculated for the larger Kiglapait Intrusion to a slower crystal accumulation rate-a 


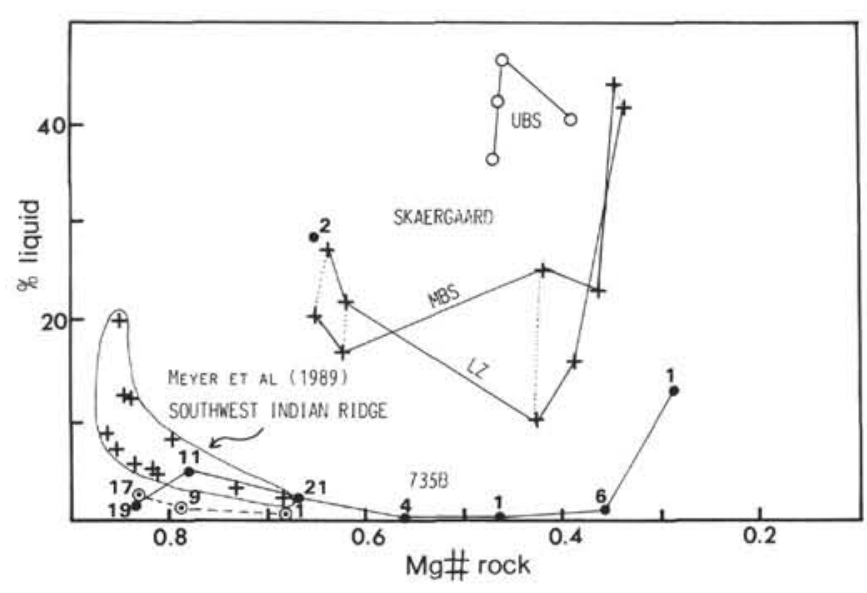

Figure 8. Comparison of residual melt porosities (\% liquid) vs. gabbro $\mathrm{Mg}$ \#s for grouped averages from Hole 735B (filled circles, circled dots), the Skaergaard Intrusion (X's), and gabbros from Shaka Fracture Zone, Southwest Indian Ridge (plusses; Meyer et al., 1989). The Hole 735B averages were computed for every increment of 0.1 difference in $\mathrm{Mg} \#$ for the top of the hole (lithologic Units I through IV; filled circles) and the bottom of the hole (lithologic Units V and VI). Numbers of samples in each average are indicated. Two samples between $\mathrm{Mg \#}=0.5$ and 0.6 with $>25 \%$ calculated porosities were separately averaged. One other, with $>53 \%$ calculated porosity is not plotted.

consequence of slower cooling. The Kiglapait rocks approach pure adcumulates in composition. "By hypothesis, the accumulation rate governs the effectiveness of adcumulus exchange by diffusion (Hess, 1939)"' (Morse, 1979b, p. 604).

By this reasoning, one might expect that the complexly crosscutting, small gabbroic bodies cored at Hole 735B, which were emplaced at high levels in the ocean crust and experienced high cooling rates that were accelerated by submarine hydrothermal processes, would retain high residual melt porosities. However, some process acted to expel almost all trapped melts from the rocks. By observation and with some of the correlations with metamorphic fabric just described that process must have been ductile deformation, which was concurrent with the crystallization of the rocks.

The rocks appear to have acted in two contrasting ways. In one, without extensive shear, the rocks behaved somewhat like a sponge being squeezed. This succeeded most effectively in pressing out of the trapped melt, but caused little more deformation than bending and cracking of minerals. Other rocks, such as those near the top of the section, experienced extensive shear, and in these, more trapped melt was eventually retained. Possibly, the presence of concentrations of trapped melt controlled the distribution of zones of shear. Alternatively, the process of shear may have been conducive to formation of fine-scale porosity structure, into which residual melts could percolate.

The process was probably similar to that inferred on the basis of rheological properties of partially molten rock to occur in the upwelling upper mantle beneath spreading ridges. Calculations of McKenzie (1984) established that only small increments of melt (as little as a few tenths of a percent) will be retained in rock simultaneously experiencing partial melting and deformation. The extremely low melt porosities calculated for many of the gabbros of Hole 735B demonstrate for crustal rocks precisely what McKenzie predicted.

One consequence of the expulsion of residual melt from the gabbros of Hole 735B during their deformation is that their compositions can be treated as those of nearly ideal adcumulates. Individual minerals did not experience re- equilibration with trapped melt, because little of it was retained. For example, the bulk rock $\mathrm{Mg \# s}$ can be considered to reflect compositions of minerals precipitated from the melt at a cotectic, with little or no shift toward the solidus compositions of more porous gabbros having high retained melt fractions (cf. Chalokwu and Grant, 1990). This will be an important consideration in some of what follows, together with an awareness that late magmatic differentiation involved melts that migrated through porous rock in an environment of shear.

\section{General Characteristics of the Liquid Line of Descent}

"Cryptic" parameters of bulk gabbro compositions can be used to infer some attributes of the liquid line of descent. As assumed for calculation of residual melt porosities, bulk $\mathrm{Mg \# s}$ should approximate those of the predominant ferromagnesian silicates in the gabbros, unless the rocks carry abundant oxide minerals. In the rocks of Hole $735 \mathrm{~B}$, the most abundant ferromagnesian silicate is clinopyroxene, except in the troctolites, where it is olivine. Modal abundances of olivine determined by point counting in all types of gabbros, except troctolites, average $3.6 \%$ for 52 samples from lithologic Units I through IV and $7.2 \%$ for 21 nontroctolitic samples from Units V and VI (see Table 3 of the "Site 735" chapter, Robinson, Von Herzen, et al., 1989). These correspond to average proportions of olivine to total ferromagnesian silicates of $11.4 \%$ and $22.4 \%$, respectively. Low-Ca pyroxene is present in only 12 of the 76 samples point counted; in these, its abundance averages $5.4 \%$.

Because residual melt porosities are so low, it is possible to estimate average liquid compositions once in equilibrium with the minerals in the gabbros, using the $\mathrm{Mg \# s}$ from the bulk compositions. This is suggested even for rocks of the Skaergaard Intrusion, although they retain moderate residual porosities, by the correspondence of calculated liquid and bulk compositions in Figure 5B.

For troctolites, the olivine-liquid relationships of either Roeder and Emslie (1970) or Duke (1976) give virtually identical results. For all other rocks, a modification of Duke's (1976) clinopyroxene-liquid relationship was used (Appendix A). The modification was simply to the intercept value in his equation and was based on comparing olivine-liquid and clinopyroxene-liquid relationships in the abyssal ferrobasaltandesite suite from the Galapagos Spreading Center (Perfit and Fornari, 1983).

In Figure 9, histograms are presented of liquid $\mathrm{Mg \# s}$ estimated in this way for Hole $735 \mathrm{~B}$ gabbroic rocks with actual $\mathrm{Mg \# s}$ for 127 glass group averages from the Indian Ocean, including 22 compositions from the Atlantis II Fracture Zone. An additional five basalts, analyzed by X-ray fluorescence during Leg 118, also are included.

The gabbro suite is bimodal and represents liquids more evolved than most of the basalt glasses. Only the troctolites appear to have crystallized from liquids corresponding to the most typical basalt glasses. Figure 10 breaks down the gabbro compositions by chemical zone and provides a comparison to liquid compositions estimated from clinopyroxenes in other Indian Ocean gabbros (Bloomer et al., 1989 and unpubl. data). The dredged gabbros correspond even less to basalt glasses than those of Hole $735 \mathrm{~B}$, being even more deficient in magnesian compositions. However, the most commonly dredged gabbros fall in between the two principal groupings at Hole $735 \mathrm{~B}$, and extremely evolved gabbros are rare.

Because abundant Fe-Ti oxides in some of the gabbros will influence $\mathrm{Mg \# s}$, estimated liquid $\mathrm{Mg \# s}$ for those rocks are too low. This is indicated by the systematic displacement of rocks containing high normative ilmenite plus magnetite from 


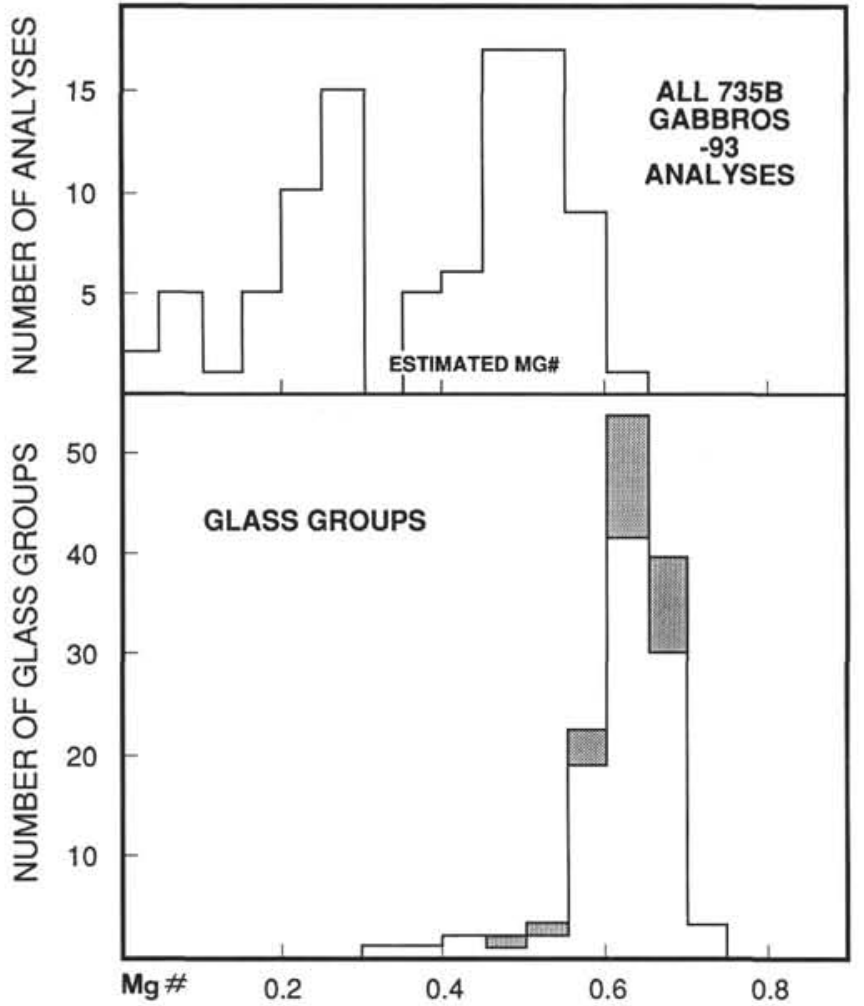

Figure 9. Histograms comparing $\mathrm{Mg} \# \mathrm{~s}$ of liquid compositions responsible for Hole 735B gabbros (upper) and Indian Ocean glasses (lower). In the lower diagram, shaded portions represent glasses from Atlantis II Fracture Zone (Table 1) plus five basalts (Leg 118).

the other evolved gabbros in Figure 10. For comparison, estimates based on clinopyroxenes from such rocks (including several having $15 \%-50 \%$ modal $\mathrm{Fe}-\mathrm{Ti}$ oxides) also are indicated, using mineral compositions tabulated later in this study. These suggest that liquid $\mathrm{Mg \# s}$ are probably underestimated by about 0.1 for oxide gabbros with $>10 \% \mathrm{Il}+\mathrm{Mt}$ in the norms. Better correspondence for samples of olivine gabbro does exist. Estimated liquid $\mathrm{Mg \# s}$ from the bulk composition of a shipboard sample and from clinopyroxenes in the sample differ by less than $0.01 \%$, consistent with the inference that the rocks have low residual melt porosities.

Figures 9 and 10 thus provide fair to good semiquantitative information about parental liquid $\mathrm{Mg \# s}$. The Ti-ferrogabbros crystallized from evolved liquids not much different up and down the hole. There are no intermediate compositions between these and more primitive olivine gabbros and troctolites, as there should be if the entire rock suite had crystallized in situ from one or more parental liquids. An intrusive relationship, with most of the Ti-ferrogabbros crosscutting olivine gabbros and troctolites, is indicated. The rocks need not necessarily be related to the identical parental liquids, as is now considered in more detail.

\section{Diversity of Parental Magmas}

Figure 5 shows that gabbros from Hole 735B are more albitic at a given $\mathrm{Mg} \#$ than equivalently magnesian gabbros from elsewhere in the Indian Ocean and the Skaergaard Intrusion. This is most likely related to systematically more sodic parental liquids, which is confirmed by glass compositions discussed in the following section. However, the gabbros themselves may carry other information about parental liquids that can be deduced from trace elements. For example,

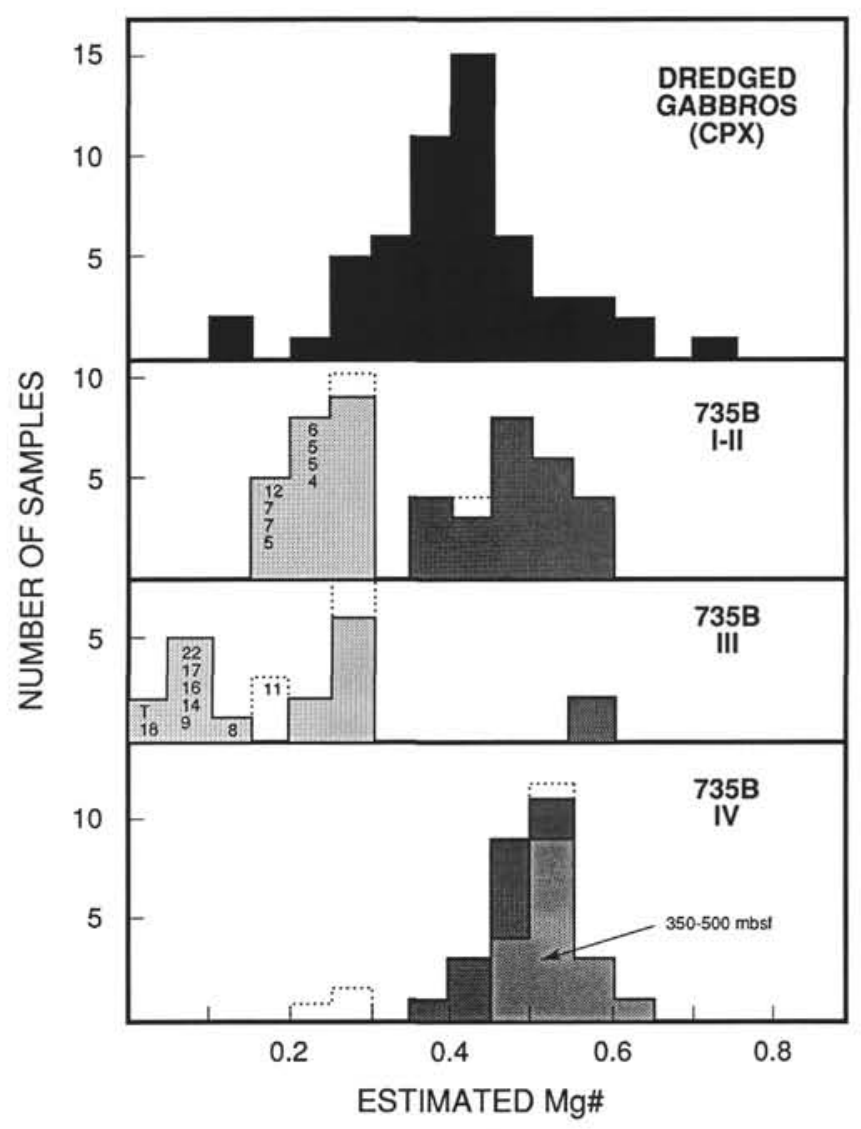

Figure 10. Additional histograms comparing dredge gabbro estimated liquid $\mathrm{Mg} \#$ s with Hole 735B gabbros, divided into chemical zones. Dredge data are based on clinopyroxenes (Bloomer et al., 1989 and unpubl. data). The numbers in the columns for low $\mathrm{Mg} \#$ gabbroic rocks from Hole 735B give the sum of normative ilmenite and magnetite in oxide-rich ferrogabbros. The tendency of rocks from the lower part of the hole to be more magnesian (including some troctolites) is suggested in the histogram for chemical Zone 4.

gabbros with high residual porosities may have $\mathrm{Y} / \mathrm{Zr}$ and $\mathrm{Zr} / \mathrm{Nb}$ ratios that are dominated by their trapped liquid fractions. Unfortunately, most residual melt porosities among Hole $735 \mathrm{~B}$ gabbros are so low that proportions of $\mathrm{Zr}, \mathrm{Y}$, and even $\mathrm{Nb}$ in cumulus phases are not negligible. Abundances of these elements in trapped liquids must be deduced after consideration of their partitioning into cumulus phases. Nevertheless, "excess" abundances in the trapped liquid component may be so low that analytical precision becomes a factor in establishing ratios.

One element that can be used to characterize parental liquids is $\mathrm{Sr}$, which behaves much as an incompatible element with respect to ferromagnesian silicates during partial melting of spinel or garnet lherzolite (e.g., Johnson et al., 1989), but which has a strongly compatible behavior toward plagioclase during crystallization differentiation in the crust. In fact, the contrasting behavior of $\mathrm{Sr}$ toward augite and plagioclase during differentiation (cf. Brooks, 1968) leads to the singular result that abundances of $\mathrm{Sr}$ in successively more fractionated tholeiitic liquids hardly change at all. The result is that whereas differences in the extent of partial melting of magnesian abyssal tholeiites and source heterogeneities can produce different initial abundances of $\mathrm{Sr}$ in parental liquids, even extensive fractionation will not obscure those original differences. This is shown in Figure 11A for two abyssal-tholeiite 
lineages from the eastern Pacific that include both high- and low-Mg\# glasses. Figure 11B indicates that basalt glasses having different initial $\mathrm{Sr}$ contents also exist in the Indian Ocean (Mahoney et al., 1989), but these do not include highly fractionated compositions. Type 3 compositions in Figure 11B correspond to basalts from the Southwest Indian Ridge generally east of Site 735 , nearer the triple junction. Several basalt compositions from Sites 732, 734, and 735 lie between Indian Ocean Type 2 and Type 3 glasses in the figure.

Now $\mathrm{Sr}$ in gabbroic rocks will reside almost entirely in plagioclases. If residual melt porosities are low, as in the gabbros of Hole 735B, the element will reside almost entirely in cumulus plagioclases, variably diluted by phases without $\mathrm{Sr}$ (olivine, oxide minerals), or with low abundances of $\mathrm{Sr}$ (pyroxenes).

A major oxide that behaves similarly is $\mathrm{Al}_{2} \mathrm{O}_{3}$. That is, it occurs in abundances of about $29 \%$ to $36 \%$ in plagioclases that crystallize from basaltic liquids, and abundances in gabbros are almost entirely a consequence of the diluting effect of olivine, pyroxenes, and oxide minerals, which contain virtually no $\mathrm{Al}_{2} \mathrm{O}_{3}$. The general effect of dilution of plagioclase by these other minerals is exhibited clearly by the gabbros of Hole $735 \mathrm{~B}$. The effect is indicated by the bold arrows pointing at constant $\mathrm{Sr} / \mathrm{Al}$ toward the origin in Figure 12.

Nevertheless, $\mathrm{Al}_{2} \mathrm{O}_{3}$, unlike $\mathrm{Sr}$, is not incompatible during partial melting. Almost all parental abyssal tholeiites arrive from the mantle containing $15 \%$ to $19 \% \mathrm{Al}_{2} \mathrm{O}_{3}$, whereas initial $\mathrm{Sr}$ contrasts in the Indian Ocean vary by a factor of four (Fig. 11B). Thus, the ratio $\mathrm{Sr} / \mathrm{Al}$ among gabbros directly reflects parental basalt compositions, expressing contrasts in source (mantle heterogeneity), process (extent of partial melting), or both. The extreme in the ocean basins is represented in Figure 12 between gabbros of DSDP Site 334 in the North Atlantic (Melson, Aumento, et al., 1977), which evidently crystallized from extremely refractory liquids (low $\mathrm{Sr} / \mathrm{Al}$ ), and those of Hole 735B (much higher Sr/Al). By contrast, Skaergaard

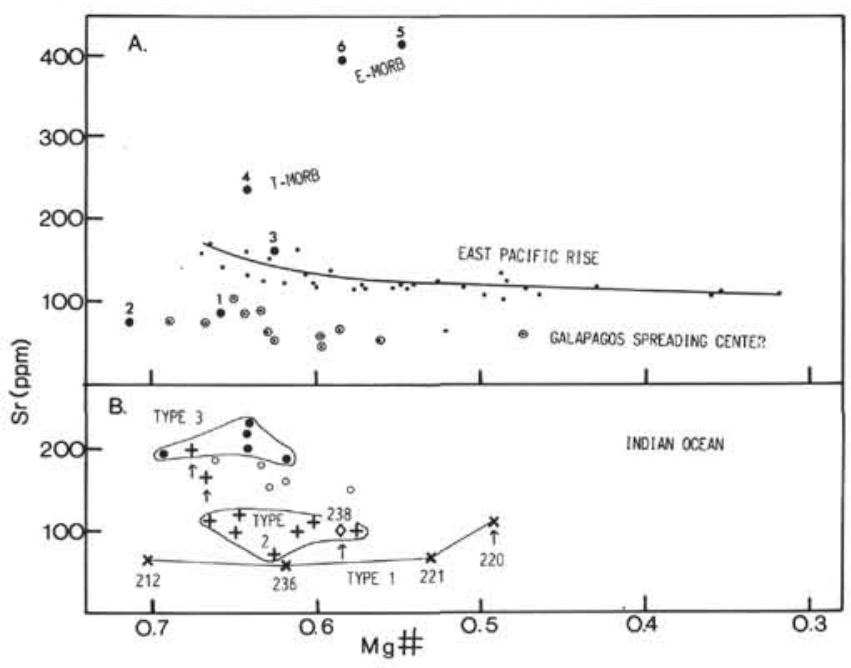

Figure 11. Sr abundances (ppm) vs. $\mathrm{Mg \#}$ for glasses from (A) the East Pacific Rise (dots; Natland, 1989 and unpubl. data) and Galapagos Spreading Center (circled dots; Mattey and Muir, 1983; Autio and Rhodes, 1983); and (B) the Indian Ocean (Mahoney et al., 1989 and Leg 118 shipboard analyses). In A, numbered data points are parental glass types 1 through 6 of Natland (1989). See Figure 13 caption, text, and Mahoney et al. (1989) for the distinctions among Indian Ocean basalt types. Symbols with vertical arrows are hot-spot-related enriched basalts. Open circles lying between Type 2 and Type 3 basalts were drilled and analyzed during Leg 118 (Robinson, Von Herzen, et al., 1989).

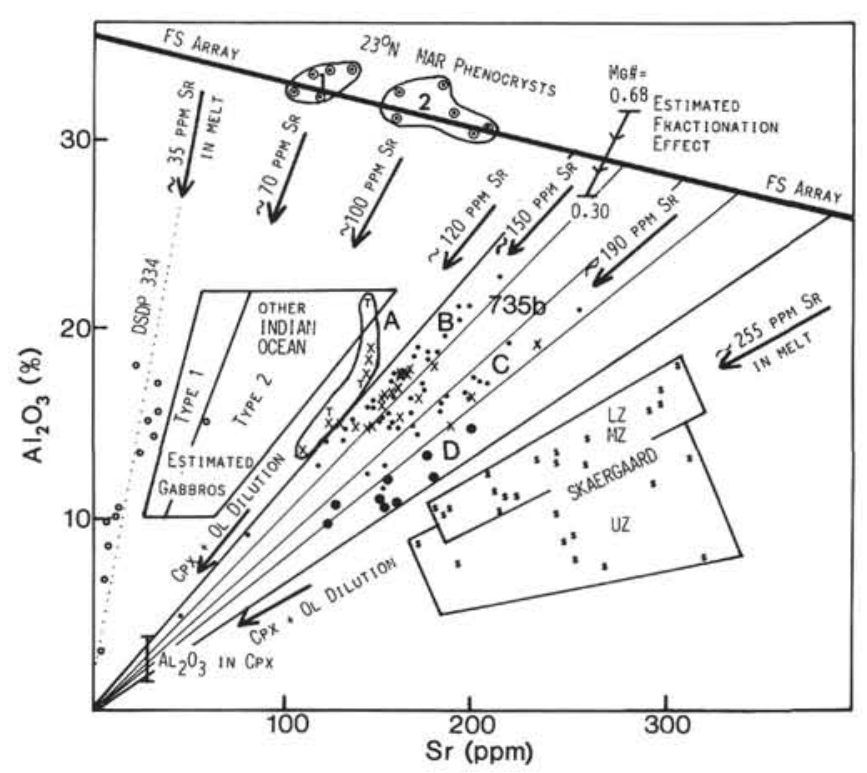

Figure 12. Sr vs. $\mathrm{Al}_{2} \mathrm{O}_{3}$ contents of gabbros from Hole 735B compared with compositions from DSDP Site 334 (North Atlantic) and the Skaergaard Intrusion. For Hole $735 \mathrm{~B}$, dots $=$ Type A through $\mathrm{C}$ basalts from lithologic Units I through IV; crosses = lithologic Units $\mathrm{V}$ and VI. Large dots = oxide ferrogabbros, mainly from lithologic Unit IV. Ts = troctolites. For Skaergaard, LZ, MZ, and UZ = Lower, Middle, and Upper Zones, respectively. Other symbols are called out in the figure. See text for the explanation of the feldspar (FS) array, the estimated fractionation effect, and the consequences of clinopyroxene plus olivine $(\mathrm{cpx}+\mathrm{ol})$ dilution.

gabbros crystallized in continental crust from even more Sr-rich liquids.

Among Hole 735B gabbros, Figure 12 shows that $\mathrm{Sr} / \mathrm{Al}$ varies by about a factor of two. This is not expected from the small variation in $\mathrm{Sr}$ produced during differentiation of individual lineages among abyssal tholeiites (Fig. 11). Therefore, the variable $\mathrm{Sr} / \mathrm{Al}$ is a strong indication that the gabbros crystallized not just from more and less fractionated liquids of high average $\mathrm{Sr}$ concentration, but from liquids derived from parental magmas with intrinsically different $\mathrm{Sr}$ contents as well. To assess this more rigorously, we have developed a simple algebraic procedure for estimating parental liquid $\mathrm{Sr}$ contents from inferred $\mathrm{Sr}$ concentrations in feldspars in the gabbros.

The bold oblique line at the top of Figure 12 is an idealized representation of what might be termed the Parental Feldspar (FS) Array for abyssal tholeiites. It is constructed in part from $\mathrm{Al}_{2} \mathrm{O}_{3}$ concentrations in near-liquidus feldspars in high- $\mathrm{Mg} \#$ Indian Ocean basalt glasses (J. Natland, unpubl. electronprobe data) and the Sr concentrations partitioned into those feldspars, as inferred from glass compositions (Mahoney et al., 1989); in addition, by extrapolation along lines of constant $\mathrm{Al} / \mathrm{Sr}$ from data points for analyzed Hole $735 \mathrm{~B}$ gabbros to $\mathrm{Al}_{2} \mathrm{O}_{3}$ contents matching those in feldspars analyzed by electron probe in the same gabbros (data of this report); and finally, by plotting of $\mathrm{Al}_{2} \mathrm{O}_{3}$ and $\mathrm{Sr}$ contents of plagioclase phenocrysts from $23^{\circ} \mathrm{N}$ on the Mid-Atlantic Ridge, which were measured directly by combined electron and ion probe procedures (Meyer and Shibata, 1989).

The full FS Array actually forms a band across the top of Figure 12 , as is suggested by the $23^{\circ} \mathrm{N}$ phenocrysts. This is because parental liquids are variably fractionated and produce feldspars with different $\mathrm{Al}_{2} \mathrm{O}_{3}$ contents. But rather than depict a cloud of points, this effect has been indicated by the 
double-arrowed line labeled "Estimated Fractionation Effect"' in Figure 12. This was placed to represent a hypothetical basalt glass suite from the Southwest Indian Ridge appropriate to Hole 735B gabbros. Within this suite, liquidus feldspar compositions for liquids ranging between $\mathrm{Mg} \#=0.68$ and 0.30 vary in estimated $\mathrm{Al}_{2} \mathrm{O}_{3}$ and $\mathrm{Sr}$ contents approximately as shown, based on phenocryst compositions and Figure 11. That is, $\mathrm{Sr}$ contents decrease by a total of about $20 \mathrm{ppm}$ through this range of $\mathrm{Mg \# s}$, and $\mathrm{Al}_{2} \mathrm{O}_{3}$ decreases from about $32 \%$ to $29 \%\left(\mathrm{An}_{80}\right.$ to $\left.\mathrm{An}_{50}\right)$. This is not enough to account for the factor-of-two variation in $\mathrm{Sr} / \mathrm{Al}$ of Hole 735B gabbros.

The bold line for the FS Array is drawn through the mid-point of the line giving Estimated Fractionation Effect and thus specifies to within about $\pm 10 \mathrm{ppm}$ the $\mathrm{Sr}$ contents of feldspars crystallized from that range of liquids, which probably represents about $90 \%$ of the subsequent crystallization of the parent with $\mathrm{Mg} \#=0.68$. The $\mathrm{Sr}$ content of average feldspar in any Hole $735 \mathrm{~B}$ gabbro thus may be specified to within about the same \pm 10 ppm using the equation of the FS Array line and the ratio $\mathrm{Sr} / \mathrm{A}$ of the gabbro (Appendix A). For other abyssal gabbros, the obliquity of trends giving fractionation effects to lines of constant $\mathrm{Sr} / \mathrm{Al}$ diminishes to the left and increases to the right; similarly, the relative error diminishes.

The trend of calculated $\mathrm{Sr}$ contents of feldspars $\left(\mathrm{Sr}_{\mathrm{F}}\right)$ from Hole $735 \mathrm{~B}$ vs. depth is plotted in Figure 7, where it can be compared with whole-rock $\mathrm{Mg} \#$ and residual melt porosity (\% trapped melt). A separate scale for estimated $\mathrm{Sr}$ in the liquid $\left(\mathrm{Sr}_{\mathrm{L}}\right)$ is indicated, based on a plagioclase/melt partition coefficient $\mathrm{D}=1.75$, computed for the Kiglapait layered intrusion (Morse, 1982). Lower distribution coefficients have been proposed based on experimental data (Philpotts and Schnetzler, 1970; Sun et al., 1974), as well as from phenocryst/liquid determinations in glassy abyssal tholeiites (Meyer and Shibata, 1989). However, the comparatively high Kiglapait distribution coefficient gives average $\mathrm{Sr}$ values for liquids calculated from Skaergaard Lower and Middle Zone bulk gabbro compositions (McBirney, 1989) that are consistent with Hoover's (1989) average chilled border composition ( 255 vs. $245 \mathrm{ppm}$ ). The $D$ value also probably increases by about $25 \%$ with percentage of crystallization (proportion of augite in the liquid; Morse, 1982); thus, an average higher value is probably appropriate for the evolved gabbros of Hole 735B. However, the increase is small enough that it could not account for the factor-of-two difference in $\mathrm{Sr} / \mathrm{Al}$ of the Hole 735B gabbros. Choice of a high $D$ value also provides one with a minimum estimate of the probable $\mathrm{Sr}$ contents of liquids responsible for Hole 735B gabbros. These values (most of them at 150-220 ppm; Fig. 12) clearly relate them primarily to Type 3 Indian Ocean basaltic parents. Estimated fields for gabbros derived from Type 2 and Type 1 Indian Ocean basalts are shown in Figure 12 for comparison.

In summary, the different $\mathrm{Sr} / \mathrm{Al}$ values of Hole $735 \mathrm{~B}$ gabbros indicate that four liquid types probably were responsible for the gabbros of Hole 735B. The distribution in the stratigraphy of the gabbros produced by the four parental types is shown by shading in Figure 7. Two of the types (A and B) are magnesian and two (C and D) are evolved. These correspond approximately, but not exclusively, with the bimodal division of the gabbro compositions based on "cryptic" parameters $\mathrm{Mg \#}$ (Fig. 7) and normative $\mathrm{An} /(\mathrm{An}+\mathrm{Ab})$. However, within each type are both less- and more-fractionated gabbro compositions.

In terms of $\mathrm{Sr}_{\mathrm{F}}$, the types also are clearly gradational, and the choice of boundaries between the groups was somewhat arbitrarily made to emphasize distinctions. However, the difference, particularly between Types B and C, is obvious in the stratigraphy (Fig. 7), except for some transitional types, which probably reflect mixing or melt infiltration where the two types alternate closely (e.g., lithologic Unit I).

In order of increasing $\mathrm{Sr}_{\mathrm{F}}$, the four types are (A) magnesian troctolites and olivine gabbros of lithologic Unit VI, with one possible example near the top of the hole; (B) somewhat less-magnesian olivine gabbros-the most abundant gabbro facies throughout the hole; (C) disseminated oxide gabbros and two oxide-rich gabbros, scattered near the top of the hole and concentrated between 175 and 220 mbsf, plus three more magnesian variants of this parentage in lithologic Units $\mathrm{V}$ and VI; and (D) oxide-rich gabbros of lithologic Unit IV between 220 and 270 mbsf, plus one more-magnesian disseminated oxide gabbro just below $400 \mathrm{~m}$. The alternation of these types in the section reinforces the impression from lithostratigraphy that this is a complex of small gabbro bodies that represent multiple intrusive events.

From the core descriptions (Robinson, Von Herzen. et al., 1989; Dick et al., this volume), the Type B olivine gabbros probably represent a substantial and homogeneous body of rock that was intruded after considerable cooling (more than once and at a number of intervals) by Type $\mathrm{C}$ disseminated oxide-gabbros. The massive Type D oxide-rich gabbros of lithologic Unit IV and their associated trondhjemites are not related geochemically to other rocks in the hole and thus appear to represent a still later intrusive event. The more magnesian Type A troctolites and related primitive olivine gabbros near the base of the hole cut both the fine-grained Type B olivine gabbros and the Type C disseminated-oxide gabbros at distinct contacts (Dick et al., this volume). They apparently were the last rocks emplaced in the section. The intrusive sequence thus proceeded from primitive to fractionated compositions through three intrusive events. This may have been a consequence of successive physical removal of the gabbro mass away from the locus of magma injection at the center of spreading and its progressive cooling and crystallization, which accentuated the fractionation of successive melts trying to penetrate it (cf. Christie and Sinton, 1981). However, the late troctolite probably was derived from a separate intrusive center (Bloomer et al., this volume).

Despite these indications of sequence, however, the magma types were supplied at their various stages of fractionation over a short period of time. That is, all the rocks experienced the same high-temperature deformation process that squeezed most trapped residual melt from the entire section. Probably, deformation and intrusion were concurrent, such that liquids from dikes or from injected crystal mushes could displace and mix with liquids being squeezed from the protolith. However, in the end, all but a tiny fraction of the residual melt was pressed from the entire body of rock.

The idea that different parental magmas supply lavas to the same accumulated section of basalts on the seafloor has been known from drilling results for some time (e.g., Autio and Rhodes, 1983; Bougault, Cande, et al., 1986). Lately, crystallization histories of individual magnesian abyssal tholeiites have been used to indicate that they are hybrids of different near-primary magmas aggregated during ascent from the mantle (Natland, 1989) and in axial magma chambers (Natland et al., 1983). The plagioclase phenocryst assemblage of the basalts from $23^{\circ} \mathrm{N}$ on the Mid-Atlantic Ridge provides another example of this process (Fig. 12). The usual supposition, however, is that the imprint of distinctive melts rising from the mantle are virtually obliterated by magma-chamber mixing.

Nevertheless, the gabbros here demonstrate that parental signatures were retained to the latest stages of differentiation of the rocks, despite the intimate juxtaposition of partially 
molten gabbroic lithofacies. In part, this has to do with the resistance of nearly crystalline host material to mixing as it was intruded by successively more fractionated magmas. But implicitly, this argues against the existence of any long-lived, homogenizing magma chamber anywhere in the path of the several magma types that produced the gabbros of Hole 735B. For the same reason, trace-element enhancements in a large, recurrently replenished, periodically tapped (RTF) magma chamber (O'Hara and Mathews, 1981) here are ruled out. The rocks of Hole 735B are consistent with both geophysical and petrological indications that there are low magma recharge rates and, consequently, small or ephemeral magma chambers at slowly-spreading ridges (Nisbet and Fowler, 1978; Natland, 1980).

Another type of magma-chamber process, however, might be significant and follows from the low calculated residual melt porosities that result from deformation processes acting on the rocks. Langmuir (1989) stressed the role of boundarylayer diffusion acting between crystals and melt on the floors and walls of layered intrusions for enhancing abundances of trace elements with low partition coefficients in successively fractionated liquids. One aspect of this is that, to the extent that ideal adcumulates can form, excluded elements will nearly be concentrated completely in the magma-chamber liquids, achieving extremely high concentrations in the last fractions of magma-chamber melt to crystallize. Conversely, the degree to which cumulates retain trapped melt will determine the fraction of those same excluded elements that was not added to the magma-chamber liquids.

The plutonic rocks of Hole $735 \mathrm{~B}$ may represent the extreme example of a crystallizing gabbro mass in which excluded elements were almost entirely contributed to successively fractionated liquids. This was not a consequence of typical adcumulus processes, but the equivalent result was achieved by ductile deformation that so strongly reduced the residual melt porosity of the partially molten rocks.

The process may have one extremely important consequence. If the lower two-thirds of the ocean crust in this vicinity consists of deformed gabbros with low residual melt porosities like those of Hole $735 \mathrm{~B}$, then it probably contains less than about $10 \%$ of the $\mathrm{Zr}$ contents of a total ocean crust section (basalts, dikes, gabbros) and virtually none of the original (magmatic) $\mathrm{P}_{2} \mathrm{O}_{5}$ or $\mathrm{K}_{2} \mathrm{O}$. Where might these elements be?

Dick et al. (this volume) show that there is insufficient trondhjemite or other silicic material in the section cored at Hole $735 \mathrm{~B}$ to make up for the deficiencies in the estimated bulk $\mathrm{TiO}_{2}$ and $\mathrm{Zr}$ compositions of the rocks, weighted by lithology. There might be more silicic material among plutonic rocks elsewhere, but this is not borne out by the extreme rarity of such rocks in dredge collections (cf. Engel and Fisher, 1975; Fisher et al., 1986). The alternative is that excluded elements were simply returned to magmas that repeatedly intruded the gabbros, and these now are contained in fine-grained dikes or lavas in the upper ocean crust. If this occurs efficiently and acts over the entire ocean crust, then the average abundances of excluded elements in the basaltic section of the crust might be enhanced by factors of 2 to 3 over the bulk composition of the crust as a whole.

Would such a process influence $\mathrm{Sr}$ abundances? Probably not. The high $D$ of $\mathrm{Sr}$ for plagioclase, and the high cotectic proportion of plagioclase through most of the crystallization range of abyssal-tholeiite magma, ensures a net crystal/melt partition coefficient for whole-rock assemblages of nearly one (Fig. 11). The concentration of $\mathrm{Sr}$ in residual liquids squeezed from the rocks did not differ significantly from that in any liquid that intruded them. There should be no net enhancement of $\mathrm{Sr}$ concentrations in the basaltic crust, nor modification of $\mathrm{Sr} / \mathrm{Al}$ ratios in the gabbros, resulting from this process. The differences in Sr/Al among gabbros of Hole 735B were imparted by different parental liquids having intrinsically different $\mathrm{Sr}$ abundances.

\section{Summary of Shipboard Results}

The gabbros of Hole 735B are compositionally bimodal with respect to the "cryptic" parameters, $\mathrm{Mg}$ \# and normative $\mathrm{An} /(\mathrm{An}+\mathrm{Ab})$, consisting of troctolites and olivine gabbros on the one hand and disseminated-oxide and oxide-rich gabbros on the other. These two principal lithofacies alternate in complex fashion in the cored section, particularly in the upper half and near the bottom of the hole. These rocks crystallized from two general sorts of liquids, namely moderately fractionated olivine tholeiite on the one hand and strongly to extremely fractionated ferrobasaltic liquids on the other. The late stages of differentiation occurred simultaneously with ductile deformation of the rocks.

The gabbros have low to extremely low calculated residual melt porosities, a consequence of the expulsion of interstitial melts during the deformation process. One result is that most of the content of excluded minor and trace elements is no longer retained in the body of rock. Nor is it explained by the minor presence of silicic trondhjemite dikelets in the section. A possibility is that excluded elements were added back into basaltic magmas that periodically intruded the crystallizing mass of rock as they passed to shallower levels in the ocean crust.

Parental liquids were sodic, based on the comparatively low normative $\mathrm{An} /(\mathrm{An}+\mathrm{Ab})$ of the gabbros. At least four distinctive, but still fairly similar, parental magma stems can be deduced from the $\mathrm{Sr} / \mathrm{Al}$ ratios of the gabbros. Estimated $\mathrm{Sr}$ contents of feldspars point to Sr-rich parental liquids, comparable to basalt glasses from the vicinity. Successively more fractionated liquids derived from these parents arrived in three separate events, each intruding the section at multiple levels. The sequence may have been a consequence of the cooling of the gabbro mass and its environs as it became physically displaced from the axis of volcanism during the spreading process. Final emplacement of troctolites suggests the onset of a new magmatic cycle at another intrusive center.

\section{GLASS COMPOSITIONS}

\section{Major Oxides}

Several glass compositions obtained from rims to basalt pillows and flows dredged from the Atlantis II Fracture Zone are listed in Table 1. The glass compositions allow us to estimate additional characteristics of liquids responsible for the Hole 735B gabbros and offer confirmation of the hypothesis concerning the whereabouts of excluded elements just presented.

Dredge hauls are from both sides of the fracture zone and at several locations, including the present ridge segments intersecting the fracture zone. The glasses are similar, with most of them being moderately fractionated abyssal tholeiites having higher-than-usual abundances of $\mathrm{TiO}_{2}$ and $\mathrm{Na}_{2} \mathrm{O}$. Two glasses are more fractionated than the rest, having $\mathrm{Mg \# s}$ of $<0.50$. In terms of $\mathrm{Na}_{2} \mathrm{O}$ contents, the suite plots partially within the field for Indian Ocean Type 2 basalt glasses (Fig. 13 ), and partly above it, but still below that for Type 3 glasses. The suite from the east side of the fracture zone (where Site 735 is located) is systematically more sodic than that from the west side of the fracture zone. The compositions of several 
Table 1. Electron probe analyses of basalt glasses, Atlantis II Fracture Zone.

\begin{tabular}{|c|c|c|c|c|c|c|c|c|}
\hline $\begin{array}{c}\text { Conrad } \\
\text { Cruise 27-09 }\end{array}$ & \multicolumn{4}{|c|}{ East side } & \multicolumn{3}{|c|}{ West side } & \multirow{2}{*}{$\begin{array}{c}\begin{array}{c}\text { Near triple } \\
\text { junction }\end{array} \\
\begin{array}{c}\text { AII93-5 } \\
6-1\end{array}\end{array}$} \\
\hline $\begin{array}{l}\text { Dredge } \\
\text { sample: }\end{array}$ & $5-3$ & $12-6$ & $3-17$ & $5-4$ & $47-1$ & $44-9$ & $44-7$ & \\
\hline $\mathrm{SiO}_{2}$ & 50.02 & 50.06 & 50.08 & 49.55 & 48.90 & 49.32 & 49.75 & 50.80 \\
\hline $\mathrm{TiO}_{2}$ & 1.69 & 1.95 & 2.23 & 3.07 & 1.71 & 2.19 & 2.53 & 1.23 \\
\hline $\mathrm{Al}_{2} \mathrm{O}_{3}$ & 15.83 & 15.69 & 14.74 & 13.78 & 15.56 & 14.87 & 13.34 & 17.27 \\
\hline $\mathrm{FeO} \#$ & 9.01 & 10.30 & 10.99 & 12.73 & 9.95 & 11.25 & 13.18 & 7.83 \\
\hline $\mathrm{MnO}$ & 0.20 & 0.24 & 0.23 & 0.24 & 0.20 & 0.24 & 0.25 & 0.153 \\
\hline $\mathrm{MgO}$ & 7.07 & 6.59 & 6.19 & 4.90 & 7.76 & 6.71 & 5.59 & 8.53 \\
\hline $\mathrm{CaO}$ & 11.20 & 10.18 & 10.55 & 9.33 & 11.09 & 10.46 & 10.37 & 10.15 \\
\hline $\mathrm{Na}_{2} \mathrm{O}$ & 3.13 & 3.25 & 3.30 & 3.68 & 2.85 & 3.26 & 3.17 & 3.64 \\
\hline $\mathrm{K}_{2} \mathrm{O}$ & 0.189 & 0.237 & 0.200 & 0.360 & 0.112 & 0.140 & 0.236 & 0.208 \\
\hline \multirow{2}{*}{$\mathrm{P}_{2} \mathrm{O}_{5}$} & 0.191 & 0.246 & 0.264 & 0.430 & 0.172 & 0.210 & 0.281 & 0.153 \\
\hline & 98.53 & 98.74 & 98.77 & 98.07 & 98.30 & 98.65 & 98.70 & 99.99 \\
\hline S(ppm) & 940 & 990 & 1105 & 1410 & 1020 & 1210 & 1470 & 690 \\
\hline${ }^{\mathrm{a}} \mathrm{Mg} \#$ & 0.619 & 0.570 & 0.539 & 0.444 & 0.618 & 0.553 & 0.468 & 0.693 \\
\hline
\end{tabular}

a Calculated assuming $\mathrm{Fe}^{2+} /\left(\mathrm{Fe}^{2+}+\mathrm{Fe}^{3+}\right)=0.86$.

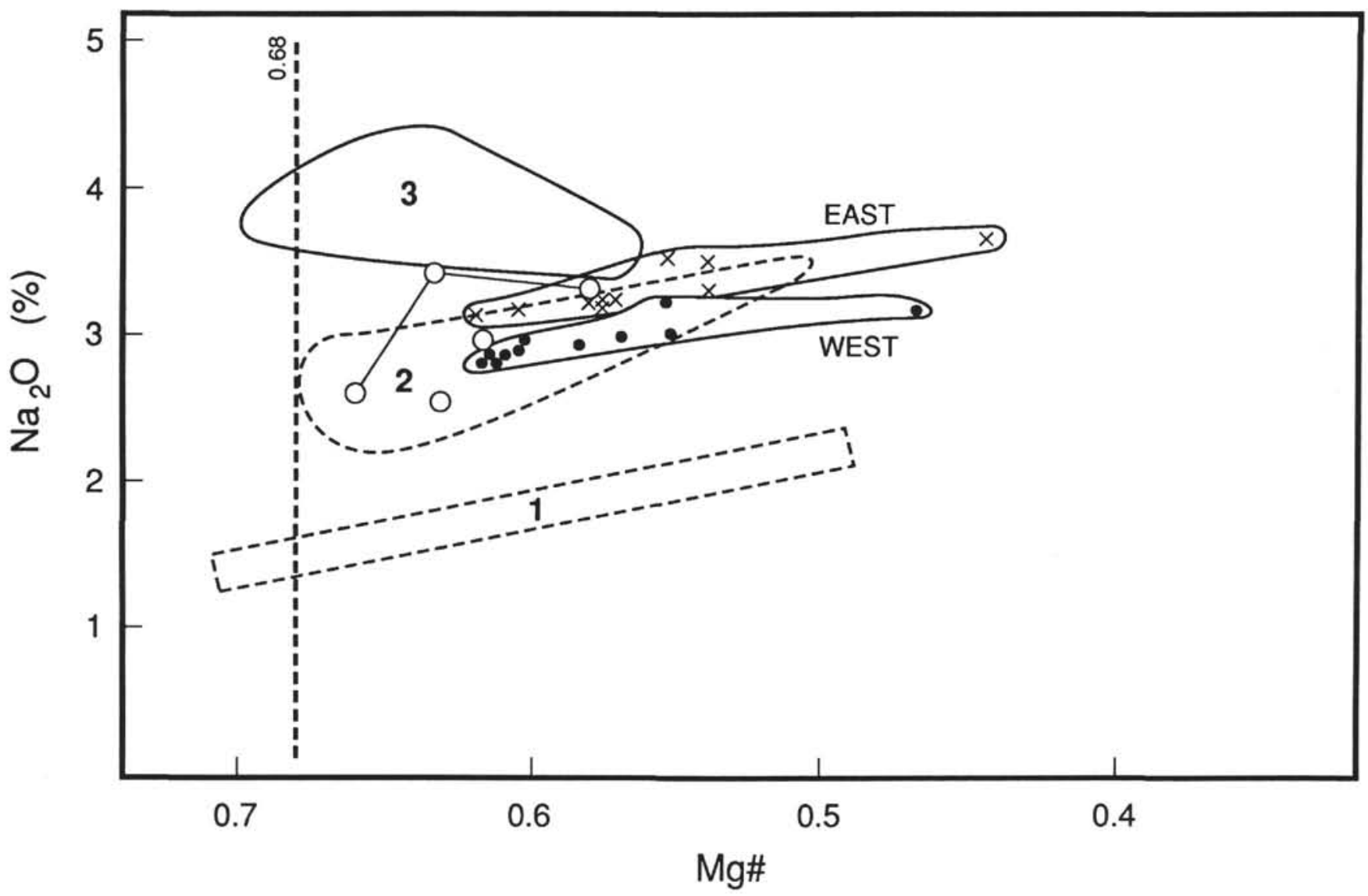

Figure 13. $\mathrm{Na}_{2} \mathrm{O}$ contents vs. $\mathrm{Mg} \#$ for basalt glasses analyzed from the Atlantis II Fracture Zone. Crosses = compositions from the east side, dots $=$ west side. Open circles $=$ basalts from Sites 732, 734, and 735 analyzed on board ship during Leg 118 . The analyses are compared to data fields for glass compositions from three geographic areas in the Indian Ocean: (1) "old" (Eocene-Cretaceous) DSDP Sites 220, 221, 236, and 212; (2) the Central Indian Ridge and Southeast Indian Ridge near the triple junction; and (3) the Southwest Indian Ridge near the triple junction and NE of Site 735 (Mahoney et al., 1989; J. Natland, unpubl. data). The dashed vertical line at $\mathrm{Mg} \#=0.68$ is a reference for estimating parental $\mathrm{Na}_{2} \mathrm{O}$ contents.

basalts drilled during Leg 118 and analyzed on board ship by $\mathrm{X}$-ray fluorescence as whole-rocks are similar, although two of the compositions have been influenced somewhat by the presence of phenocrysts.

None of the glasses is particularly magnesian. Another basalt from this general region, dredged from the axial rift of the Southwest Indian Ridge about $70 \mathrm{~km}$ west of the Indian Ocean triple junction, has a $\mathrm{Mg} \#>0.69$ (AII 93-5, 6 in Table 1). This rock is the most magnesian Type 3 basalt thus far recovered. The primitive parents to Hole $735 \mathrm{~B}$ gabbros probably had Mg\#s this high or slightly higher when they arrived at the base of the crust. 


\section{$\mathrm{K}_{2} \mathrm{O}$ and $\mathrm{P}_{2} \mathrm{O}_{5}$ Abundances and Enhancements}

The glasses have the typical low $\mathrm{K}_{2} \mathrm{O}$ and $\mathrm{P}_{2} \mathrm{O}_{5}$ abundances of depleted abyssal tholeiites, with fairly small ranges in $\mathrm{K}_{2} \mathrm{O} / \mathrm{P}_{2} \mathrm{O}_{5}$ and $\mathrm{TiO}_{2} / \mathrm{P}_{2} \mathrm{O}_{5}$ (averages for 17 compositions \pm 1 s.d. $=0.84 \pm 0.15$ and $8.98 \pm 0.95$, respectively). Other ratios of incompatible elements should be equally consistent. The small range in $\mathrm{K}_{2} \mathrm{O} / \mathrm{P}_{2} \mathrm{O}_{5}$ is restricted in view of the factor-offour variation in the ratio along the Central Indian Ridge (Mahoney et al., 1989). Presumably, this is because the Atlantis II Fracture Zone is well removed from the influence of enriched melt sources that are associated with mantle plumes (the nearest here is at Marion and Prince Edward Islands, more than $1500 \mathrm{~km}$ to the southwest).

Nevertheless, within the group of samples, small but significant differences exist in abundances of minor oxides. As with $\mathrm{Na}_{2} \mathrm{O}$, the contents of both $\mathrm{K}_{2} \mathrm{O}$, and $\mathrm{P}_{2} \mathrm{O}_{5}$ are systematically lower at given $\mathrm{Mg \# s}$ in samples from the west side than in those from the east side of the fracture zone (Table 1). That is, the basalts on the east side are more like Type 3 basalts from near the triple junction farther northeast. The Atlantis II Fracture Zone thus represents a fracture-zone discontinuity in basalt chemical compositions (Langmuir and Bender, 1984); however, the analyses indicate that the overall transition to Type 3 basalts near the triple junction is gradational along this portion of the Southwest Indian Ridge. Comparing primitive compositions only $(\mathrm{Mg} \# \mathrm{~s}>0.6)$, glasses from the Atlantis II Fracture Zone are intermediate in composition between Type 2 and Type 3 Indian Ocean basalts for all three oxides; samples analyzed on board ship indicate that this comparison applies to $\mathrm{Sr}$ as well (Fig. 11).

For more fractionated compositions, the intermediate attributes of the glasses between Type 2 and Type 3 basalts are still apt for $\mathrm{Na}_{2} \mathrm{O}$ contents, but $\mathrm{K}_{2} \mathrm{O}$ and $\mathrm{P}_{2} \mathrm{O}_{5}$ abundances are excessive, more so at low Mg\# (e.g., Conrad Sample 27-9, 5-4 in Table 1). This is shown for $\mathrm{P}_{2} \mathrm{O}_{5}$ plotted vs. $\mathrm{TiO}_{2}$ as an index of differentiation in Figure 14A. Samples from the east side of the fracture zone trend obliquely to a trend for a more extended fractionation sequence from the East Pacific Rise (Fig. 14A). A similar comparison can be made for $\mathrm{K}_{2} \mathrm{O}$, although its pattern for the East Pacific Rise is complex, because of the influence of enriched alkalic basalts mixed into tholeiites, which increased their $\mathrm{K}_{2} \mathrm{O} / \mathrm{P}_{2} \mathrm{O}_{5}$ ratios (Natland, 1989). Such mixing can also increase $\mathrm{P}_{2} \mathrm{O}_{5}$ abundances slightly with respect to $\mathrm{TiO}_{2}$ contents; thus, the inferred "clean" fractionation trend for the East Pacific Rise in Figure 14 is drawn to minimize this effect.

In contrast to the East Pacific Rise, some process clearly acted at the Atlantis II Fracture Zone and at adjoining ridge segments to enhance $\mathrm{K}_{2} \mathrm{O}$ and $\mathrm{P}_{2} \mathrm{O}_{5}$ abundances in glasses, but in proportion. There is no sign that an enriched component has modified the $\mathrm{K}_{2} \mathrm{O} / \mathrm{P}_{2} \mathrm{O}_{5}$ ratio of any of the glasses. The process is more greatly manifested among samples from the east side than from the west side of the fracture zone, but this may simply be an artifact of sampling. Shipboard basalt samples analyzed by X-ray fluorescence show exactly the same trend (Fig. 14A) and include one sample, a foliated metabasalt from Site $734(118-734 \mathrm{R}-1 \mathrm{R}-1,74-77 \mathrm{~cm})$ with high $\mathrm{P}_{2} \mathrm{O}_{5}$ and $\mathrm{TiO}_{2}$ contents similar to abundances in dredged glass Conrad Sample 27-09, 5-4 in Table 1. A drilled porphyroclastic metagabbro from the same site (118-734D-1R-1, 59-61) has an even more extreme composition (at higher $\mathrm{P}_{2} \mathrm{O}_{5}$ and $\mathrm{TiO}_{2}$ contents), but that extrapolates along the same trend. This metagabbro has $0.45 \% \mathrm{~K}_{2} \mathrm{O}$. The two samples also have elevated abundances of $\mathrm{Zr}, \mathrm{Y}$, and $\mathrm{Nb}$; however, the ratios of these elements are similar to those in unmetamorphosed tholeiitic basalts (N-MORB) analyzed during Leg 118 (see

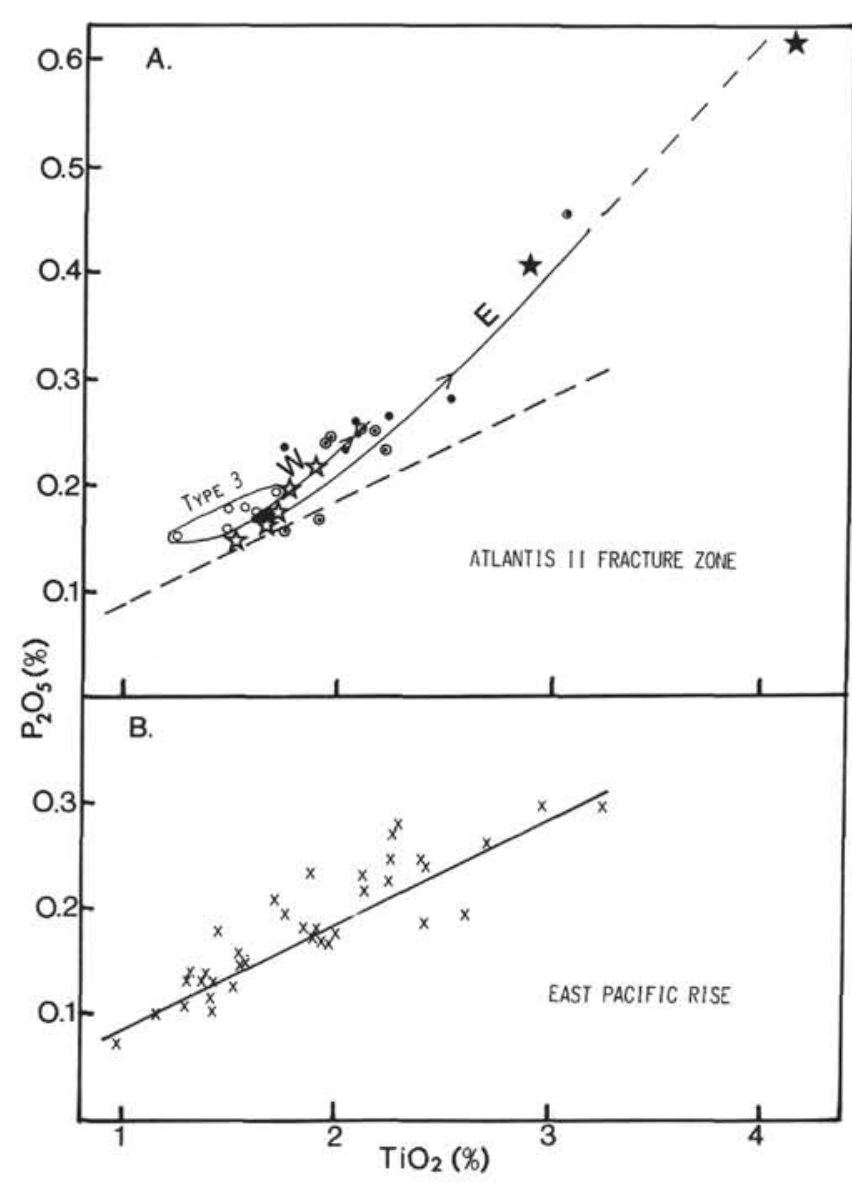

Figure 14. $\mathrm{TiO}_{2}$ vs. $\mathrm{P}_{2} \mathrm{O}_{5}$ contents of (A) glasses from Atlantis II Fracture Zone (Table 1 and Dick et al., this volume) and (B) the East Pacific Rise (Natland, 1989 and unpubl. data). Samples in A are from the west side (dots) and east side (circled dots) of the fracture zone and from Leg 118 (crosses). For comparison, Type 3 Indian Ocean glasses (J. Natland, unpubl. data) are also shown in A. The dashed line in A is the solid line in B and represents an idealized fractionation trend for basalts from the East Pacific Rise that have no admixed alkalic basalt component (see text).

"Site 734" chapter, Robinson, Von Herzen, et al., 1989). These two samples thus are recrystallized basalts having unusually high abundances of excluded elements.

The two samples have such compositions either because they directly represent residual melts expelled from the gabbros by ductile deformation, or because they contain a considerable fraction of such melts. They confirm that not all such liquids escaped the zone of deformation. Moreover, the same two samples have $\mathrm{Sr}$ contents similar to abundances in the several other basalts analyzed during Leg 118 . The process of enhancement of excluded trace and minor elements did not affect Sr.

\section{Sulfur}

A surprising result of electron probe analysis of the glasses is that the contents of $\mathrm{S}$ are unusually low for abyssal tholeiites, at $200-300 \mathrm{ppm}$, lower than in basalts at sulfide saturation through a similar range in $\mathrm{Fe}$ content (Fig. 15) found in the eastern Pacific and North Atlantic (Mathez, 1976, 1980; Perfit and Fornari, 1983). Presumably, this means that these glasses are not at sulfide saturation; hence, sulfur can be considered an incompatible element, such that immiscible 


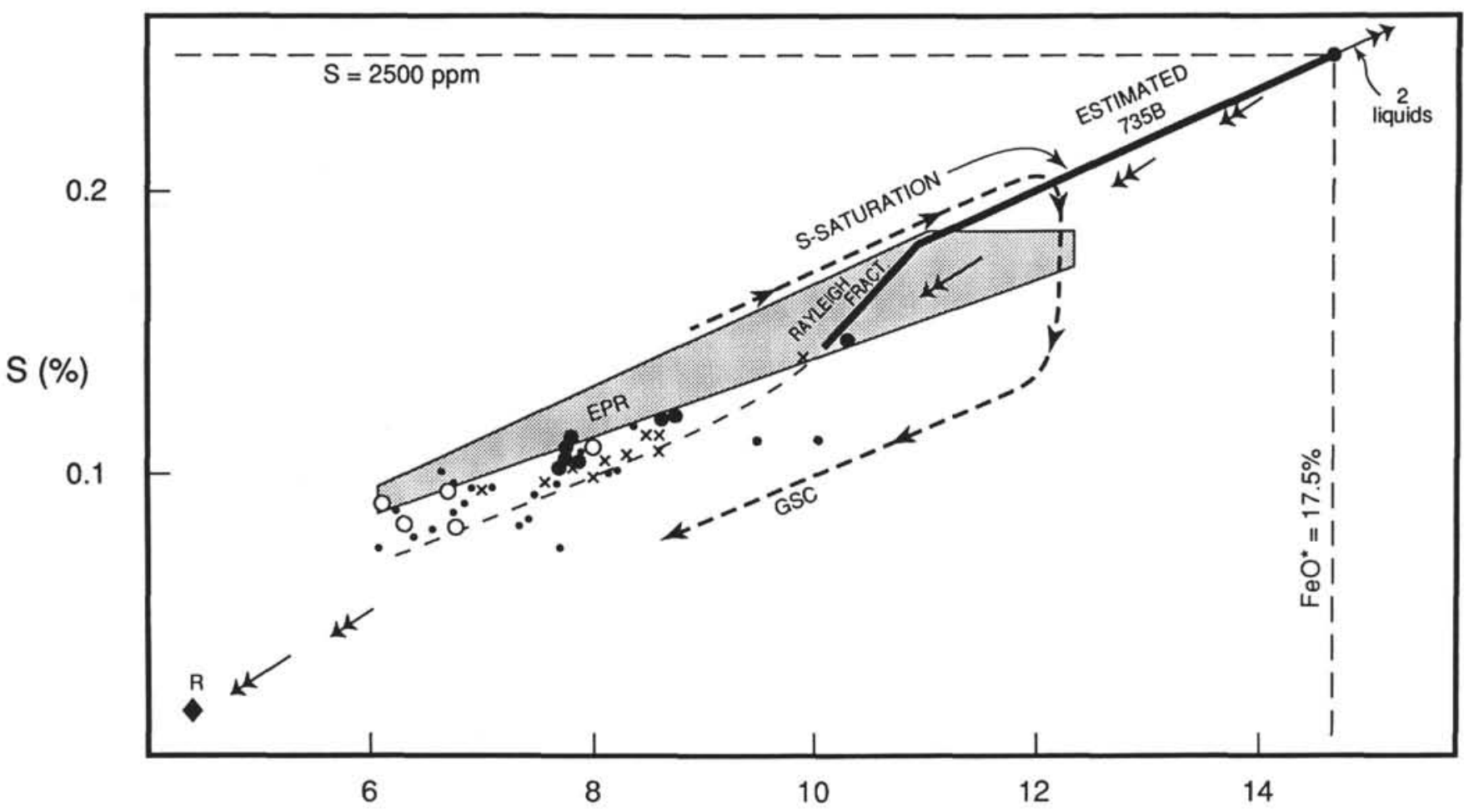

$\mathrm{Fe}(\%)$

Figure 15. S vs. Fe for glasses from the Southwest Indian Ridge and Atlantis II Fracture Zone. Symbols = those in Figure 13, except for R, a rhyodacite from the East Pacific Rise. The shaded field is for basalts of the East Pacific Rise analyzed for Sr in the same microprobe runs as those from Atlantis II Fracture Zone. The glasses from the East Pacific Rise are at sulfide saturation. The curved dashed trend is for the Galapagos Spreading Center (Perfit and Fornari, 1983); it curves away from S saturation at the point when titanomagnetite joins the liquidus. The trend estimated for liquids from which Hole 735B gabbros crystallized is assumed to follow the bold line to sulfide saturation and eventual immiscible separation of two liquids, as discussed in the text.

sulfide segregation did not occur throughout the range of differentiation represented by the glasses, to $\mathrm{Mg \#}$ as low as 0.44 . This is an attribute of a number of other Indian Ocean basalt glasses, including Type 3 basalts from the Southwest Indian Ridge near the triple junction (Fig. 15).

Sulfur shares the characteristics of $\mathrm{Na}_{2} \mathrm{O}, \mathrm{K}_{2} \mathrm{O}$, and $\mathrm{P}_{2} \mathrm{O}_{5}$ by being lower in abundance in glass samples from the east side of the Atlantis II Fracture Zone than in those from the west side. Within each group, sulfur abundances increase with fractionation (shown as iron enrichment in Fig. 15). However, sulfur does not increase in proportion to $\mathrm{K}_{2} \mathrm{O}$ and $\mathrm{P}_{2} \mathrm{O}_{5}$ abundances; therefore, it did not behave as an ideally incompatible element during the deformation process that enhanced the abundances of these excluded elements in the glasses. The explanation for this is obvious from petrographic examination of disseminated-oxide and oxide-rich gabbros, many of which have virtually no residual porosity, but all of which carry the abundant sulfide globules associated with oxide minerals. Clearly, sulfur was retained in the matrix of these gabbros while their residual liquids were squeezed from them and added back into intrusive basalts. Thus, no inconsistency exists when describing sulfur as an incompatible element with respect to the fractionation processes that acted on these glasses, even though $\mathrm{K}_{2} \mathrm{O}$ and $\mathrm{P}_{2} \mathrm{O}_{5}$ behaved differently.

The low contents of sulfur in these glasses, and of Indian Ocean glasses in general, evidently relates to properties of mantle sources in this region. Even small degrees of partial melting (which produce sodic and titanium Type 3 basalts) appear to exhaust its supply of sulfur, in contrast to those regions of the North Atlantic where sulfide spherules are found even in the most primitive basalts (e.g., Czamanske and Moore, 1977).

\section{Summary}

With respect to the extended differentiation of Hole 735B gabbros, the most important aspects of the glass compositions are (1) initially high abundances of $\mathrm{TiO}_{2}$, accentuated as differentiation proceeds and (2) initially low sulfur. These are consequences of degree of partial melting and mantle source compositions, respectively. The glasses, and several basalts and metamorphosed basalts analyzed during Leg 118 , provide evidence for the disposition of excluded elements during the removal by force of interstitial melts in crystallizing gabbros during ductile deformation. Incompatible elements wound up mainly being reincorporated into basaltic magmas that periodically intruded the deforming mass of partially molten rock en route to injection of the uppermost crust as dikes or extrusion onto the seafloor. $\mathrm{K}_{2} \mathrm{O}$ and $\mathrm{P}_{2} \mathrm{O}_{5}$ behaved coherently during this process, but sulfur was retained in sulfide globules in the disseminated-oxide and oxide-rich gabbros; it was not expelled when interstitial melts were squeezed from the rocks. 


\section{MINERALOGY}

\section{Petrographic Summary}

The most important petrographic observations pertaining to the late-stage liquid line of descent are (1) evidence for two intervals of olivine crystallization, one at high $\mathrm{Mg} \#$, the other at low $\mathrm{Mg \# ;} \mathrm{(2)} \mathrm{no} \mathrm{indication} \mathrm{that} \mathrm{titanomagnetite} \mathrm{crystallized}$ as a cumulus phase at a stage early enough to produce siliceous liquids (ilmenite is another matter); and (3) predominance of ilmenite over magnetite in all oxide-rich gabbros. In addition, globular sulfides of magmatic origin are virtually absent in the more magnesian olivine gabbros and occur exclusively in intercumulus portions of such rocks, where that texture can be recognized. However, they are extremely abundant in Ti-ferrogabbros, where they are consistently associated with, and most abundant in, concentrations of ilmenite and lesser magnetite. Principal sulfides in the globules are pyrrhotite or pyrite and chalcopyrite.

The existence of two intervals of olivine crystallization has been inferred petrographically from the absence of olivine in oxide-poor rocks carrying two pyroxenes (gabbronorites and norites). Yet, iron-rich olivine $\left(\mathrm{Fo}_{40-30}\right.$, based on microprobe data) occurs in many oxide gabbros. The situation is a bit confused by the paucity of gabbros with intermediate compositions (Fig. 8); however, enough noritic rocks do exist to support the contention that they represent part of the hiatus in olivine crystallization between that of the magnesian gabbros on the one hand and Ti-ferrogabbros on the other.

This provides yet another similarity to the Skaergaard Intrusion, where two intervals of olivine crystallization are considered evidence for extended high-iron differentiation, with little or no influence of magnetite on the liquid line of descent (cf. Wager and Brown, 1967). This inference was based on comparison of experiments in the system MgO-FeO$\mathrm{SiO}_{2}$ (Bowen and Schairer, 1935) to those in which $\mathrm{Fe}_{2} \mathrm{O}_{3}$ was an additional component (Osborne, 1959). At sufficiently high oxygen fugacities, the olivine primary phase volume is restricted by incursion of the magnetite volume (Osborn, 1979), and liquids crystallizing two pyroxenes will differentiate toward the latter, where marked $\mathrm{SiO}_{2}$ enrichment will occur, rather than encounter the olivine phase volume again. This is evidently what happened at the Galapagos Spreading Center, where rocks with $\mathrm{SiO}_{2}$ contents between $53 \%$ and $64 \%$ and $\mathrm{Mg \# s}$ between 0.37 and 0.17 have titanomagnetite, rather than olivine, quenched in glass (Perfit and Fornari, 1983). The $\mathrm{Mg \# s}$ overlap those inferred for liquids producing the fractionated group of gabbros from Hole 735B (Fig. 9).

Finally, iron-titanium oxides in the Hole $735 \mathrm{~B}$ oxide gabbros, together with their associated subordinate sulfides, clearly were able to fill cracks, fractures, and other porosity structures that developed during deformation of the rocks (i.e., Figs. 20 and 21 on page 121, "Site 735 " chapter, Robinson, Von Herzen, et al., 1989). This is one aspect of the overall process that led to the high concentrations of oxides in some rocks wherein, for tens of centimeters along the core, coarse aggregates of silicate minerals appear to be virtually matrix-supported by the oxide concentrates. In these rocks, many of which contain the later, iron-rich olivine, oxide minerals appear to have engulfed the silicates, most of which were previously bent, twisted, partially crystallized, and foliated. These textures do not extend through the oxide concentrates and thus formed prior to oxide crystallization. The only way to interpret these relationships is that formation of oxide concentrates occurred during and after deformation of the rocks. The trondhjemites also penetrated deformed rocks, proving concurrence of late-stage magmatic differenti- ation and brittle/ductile deformation. In terms of the paragenesis of magmatic minerals, oxide minerals clearly formed after crystallization of pyroxenes, sodic plagioclases, and iron-rich olivines in these most-evolved gabbroic rocks of Hole 735B.

\section{Mineral Compositions}

Mineral data are reported in Tables 2 through 4 and in Appendix B for 18 samples, which chiefly represent disseminated-oxide and oxide gabbros from the massive oxide interval (lithologic Unit IV) and short intervals near the top and toward the bottom of the hole. Several olivine gabbros also were studied, including the thin section from Core 118-735B$35 \mathrm{R}$ previously described as containing a contact between olivine and oxide gabbros (Fig. 4). In addition, a trondhjemitic dikelet from Core 118-735B-53R was examined. Samples include extremely deformed metagabbros from lithologic Unit I (Cores 118-735B-2D and -3D) and represent the full range in proportion of oxide minerals (none in the sample from Core 118-735B-16R; more than $50 \%$ in the thin section from Core 118-735B-47R).

Table 2 is a list of reduced data only, plus some individual oxides for silicates, to allow one to compare coexisting phases. Complete analyses can be found in Appendix B. Oxide minerals and sulfides listed in Tables 3 and 4 are representative. Because our concern here is to place crystallization of oxides and sulfides along the liquid line of descent, silicates are considered first.

\section{Olivines and Plagioclases}

Olivines in four olivine gabbros range in compositions from $\mathrm{Fo}_{80.7}$ to $\mathrm{Fo}_{60.6}$ (Table 2; Appendix B). Plagioclases in the same rocks range from $\mathrm{An}_{65.3}$ to $\mathrm{An}_{45.9}$. Corresponding compositions in the first interval of olivine crystallization at Skaergaard are $\mathrm{Fo}_{68-53}$ and $\mathrm{An}_{67-50}$. Hole 735B samples without olivine in this study have plagioclases ranging from $\mathrm{An}_{43-36}$. At Skaergaard, they are $\mathrm{An}_{50-40}$. Oxide gabbros from Hole 735B have olivines between $\mathrm{Fo}_{40.6}$ and $\mathrm{Fo}_{34.2}$. Plagioclases are between $\mathrm{An}_{36.7}$ and $\mathrm{An}_{31.3}$. Corresponding minerals during the second stage of olivine crystallization at Skaergaard in Upper Zone a of the Layered Series are $\mathrm{Fo}_{40-30}$ and $\mathrm{An}_{46-42}$ (Wager and Brown, 1967). There is nothing from Hole $735 \mathrm{~B}$ that corresponds to more-evolved Skaergaard rocks higher in the Layered Series nor to the Upper Border Group, except the trondhjemite, which resembles the Tinden granophyre. The trondhjemite has no olivine, and the plagioclase is $\mathrm{An}_{20.3}$.

Overall, these results point to close correspondence of Hole $735 \mathrm{~B}$ gabbros to the mineralogy of the Skaergaard sequence, including the two intervals of olivine crystallization. Feldspars in the more fractionated gabbros of Hole 735B are more sodic than those in comparable Skaergaard gabbros because of the more sodic compositions of parental magmas (Table 1; Fig. 12).

\section{Pyroxenes}

Pyroxene compositions obtained during this study (Table 2; Appendix B) are plotted in Figure 16. The high-Ca pyroxenes range in composition from endiopside and diopside to augite; low-Ca pyroxenes are hypersthene and ferrohypersthene. In relationship to Skaergaard pyroxenes, compositions generally fall between the solidus and subsolidus trends (Nwe, 1976), indicating that extensive recrystallization took place. Approximate temperatures of recrystallization are mainly between $600^{\circ}$ and $800^{\circ} \mathrm{C}$, based on both low-Ca and high-Ca pyroxenes (Lindsley, 1983). Individual samples have variable pyroxene compositions, as indicated by lines linking data points for several samples. That is, near-solidus clinopyroxenes occur in two olivine gabbros, as well as more diop- 
sidic recrystallized grains; one oxide gabbro retains some pigeonite, although most low-Ca pyroxenes in the sample have been recrystallized.

Tie-lines link pyroxene pairs from four samples to indicate the general course of iron enrichment during differentiation. Recrystallization tended to make both low-Ca and high-Ca pyroxenes slightly more magnesian than solidus compositions. Recrystallized clinopyroxenes produce estimates of liquid $\mathrm{Mg \# s}$, using the procedure described earlier, somewhat higher than those of olivines, or near-solidus clinopyroxenes, from the same samples. Taking this into account, the onset of crystallization of low-Ca pyroxene in this sample suite may have begun when host liquids had $\mathrm{Mg} \# \mathrm{~s}$ somewhere between 0.45 and 0.34 , probably closer to the latter. Again, this assumes that expulsion of interstitial melts during deformation kept the minerals from re-equilibrating with cooler melts.

Apart from the trondhjemite, the range of pyroxene compositions corresponds well to crystallization of the Skaergaard Layered Series into Upper Zone a composition. The very iron-rich pyroxenes of Skaergaard sequences higher in the Layered Series and in the Upper Border Group have no counterparts in the rocks from Hole 735B.

Two minor oxides, $\mathrm{TiO}_{2}$ and $\mathrm{MnO}$, in clinopyroxenes are plotted vs. Mg\# in Figure 17. Duke (1976) determined that the partition coefficient, $D$, for $\mathrm{Ti}$ between basaltic melt and clinopyroxene $=0.29$. This agrees with an empirical estimate using phenocrysts in magnesian abyssal tholeiites from elsewhere in the Indian Ocean, as shown in Figure 17A. Based on this, $\mathrm{TiO}_{2}$ contents of initial parental liquids were high, perhaps $1.6 \%$ or more, in accord with the high $\mathrm{TiO}_{2}$ concentrations in basalt glasses from the Atlantis II Fracture Zone (Table 1). The maximum $\mathrm{TiO}_{2}$ contents of liquids responsible for Hole $735 \mathrm{~B}$ gabbros may have been about $3.5 \%$ in liquids with $\mathrm{Mg \# s}$ of 0.35 to 0.40 ; in more fractionated liquids, from which the oxide gabbros crystallized, $\mathrm{TiO}_{2}$ contents were less. This is most readily explained by the addition of iron-titanium oxides, either ilmenite alone, or both ilmenite and magnetite, to liquidus assemblages.

Some oxide gabbros have pyroxenes with a substantial range in $\mathrm{TiO}_{2}$ contents. Some fall well below the normal range suggested by the trend lines in Figure 17A. The unusually low $\mathrm{TiO}_{2}$ contents suggest crystallization or recrystallization in the presence of highly evolved intercumulus liquids with low $\mathrm{TiO}_{2}$ contents, perhaps similar to the trondhjemite, for which pyroxene compositions are labeled in Figure 17A.

$\mathrm{MnO}$ contents in clinopyroxenes (Fig. 17B) increase systematically with their iron content (decreasing En/[En + Fs]). Clinopyroxenes in the trondhjemite fall on the trend at nearly the highest $\mathrm{MnO}$ contents, demonstrating close affinity between liquids which produce them and the oxide gabbros. The proportions of $\mathrm{MnO}, \mathrm{FeO}$, and $\mathrm{MgO}$ in the liquids were virtually identical, regardless of any differences in $\mathrm{SiO}_{2}$ or alkali contents.

\section{Oxide Minerals}

Minerals heretofore termed ilmenite and magnetite are actually Il-Hem and Mt-Usp solid solutions, respectively (Table 3). However, because of recrystallization, the compositions come close to being end-member ilmenite and magnetite in the samples studied. Oxide pairs were used to calculate temperatures and oxygen fugacities of recrystallization, using Spencer and Lindsley's method (1981), with the modification by Stormer (1983). Calculated temperatures have been plotted vs. average plagioclase compositions of host samples in Figure 18 . Most pairs give low temperatures within a very narrow range, regardless of plagioclase compositions (see inset in Fig. 18). A few oxide pairs, representing minerals enclosed in large porphyroclasts in deformed rocks or large mineral grains in less deformed rocks, give higher temperatures; the temperature for an oxide pair in symplectic intergrowth with pyroxene is $900^{\circ} \mathrm{C}$. But the consistent temperatures deduced for most oxide pairs effectively define an important thermal event in the history of these rocks. The temperatures, centered at about $620^{\circ} \mathrm{C}$, are close to estimated temperatures of formation of titanium and iron-rich brown amphiboles, which are closely associated with oxide minerals in most samples (Stakes et al., this volume). These temperatures are somewhat lower than those estimated for most recrystallized pyroxenes, suggesting that the transformation between ductile deformation and static recrystallization under hydrous conditions took place between about $900^{\circ}$ and $600^{\circ} \mathrm{C}$.

Recrystallization also took place at low oxygen fugacities $\left(10^{-17}\right.$ to $\left.10^{-22} \mathrm{~atm}\right)$ at or near the fayalite-magnetite-quartz (FMQ) buffer (Fig. 19). Conditions correspond to the least temperatures estimated for recrystallization of any oxides at the Skaergaard Intrusion (Fig. 18), which also took place near FMQ (Fig. 19). Oxygen fugacities are 2 to $3 \log$ units below the nickel-nickel oxide buffer (NNO), near $\delta$ NNO values for abyssal-tholeiite glasses (Christie et al., 1986). This clearly establishes that oxygenating conditions of alteration-commonly inferred for the uppermost basalts in the ocean crustdid not extend into the gabbroic layer during the recrystallization of oxide minerals at this location.

Petrographic observations of the oxide gabbros from Hole $735 \mathrm{~B}$ also suggest that recrystallization of oxide minerals took place partly at the expense of magnetite, from which components evidently were provided to brown amphiboles. In gneissic/porphyroclastic samples of lithologic Unit I, which have abundant brown amphibole and a few percent of ilmenite, no magnetite appears. In oxide-rich gabbros, however, abundant magnetite remains in coarse two-oxide intergrowths that were unaffected by this process. Still, the proportions of ilmenite and magnetite in such samples have probably been modified by alteration, particularly around the edges of the intergrowths, which makes it difficult to establish original modes that would allow one to reconstruct their compositions at magmatic temperatures.

Nevertheless, oxide concentrates are distinctly dominated by ilmenite. In one olivine gabbro sample lacking brown amphibole, ilmenite is the only primary oxide mineral. In most Ti-ferrogabbros, the proportion of ilmenite typically is $\mathbf{1 0}$ times or more that of magnetite. The magnetite is unquestionably primary, because it is intergrown with, not exsolved from, ilmenite. Nor could it have acquired its $\mathrm{Al}_{2} \mathrm{O}_{3}$ from re-equilibration with ilmenite. However, it was far from being the principal oxide mineral on the liquidus at the time it crystallized.

Abundances of minor elements in the oxide minerals differ from liquidus oxides described from highly evolved volcanic rocks in oceanic settings, and-again-cumulus oxides in the Skaergaard Intrusion. In Figures 20 and 21, ilmenites and magnetites are compared, respectively. Combining information from the Galapagos Spreading Center (Perfit and Fornari, 1983), Thingmuli volcano in Iceland (Carmichael, 1967), Skaergaard (Vincent and Phillips, 1954; Naslund, 1984), and an abyssal-gabbro xenolith suite from Jasper Seamount off northern Mexico (Gee et al., in press; J. Gee and J. Natland, unpubl. data), general trend lines showing the change of mineral compositions during differentiation are inferred. Hole $735 \mathrm{~B}$ oxide minerals have $\mathrm{MgO}$ contents so low that they overlap only the most evolved 
Table 2. Silicate mineral summary (intergrown pyroxenes listed side by side).

\begin{tabular}{|c|c|c|c|c|c|c|c|c|c|c|c|c|}
\hline \multirow{2}{*}{$\begin{array}{l}\text { Sample } \\
118-735 B-\end{array}$} & \multirow{2}{*}{$\begin{array}{l}\mathrm{OL}^{\mathrm{I}} \\
\mathrm{Fo}(\%)\end{array}$} & \multirow{2}{*}{$\begin{array}{r}\text { PLAG } \\
\text { An }(\%)\end{array}$} & \multicolumn{5}{|c|}{ Clnopyroxene } & \multicolumn{5}{|c|}{ Low-Ca pyroxene } \\
\hline & & & Wo & En & Fs & $\mathrm{TiO}_{2}$ & $\mathrm{MnO}$ & Wo & En & Fs & $\mathrm{TiO}_{2}$ & $\mathrm{MnO}$ \\
\hline \multicolumn{13}{|l|}{$2 \mathrm{D}-1,145-179$} \\
\hline Foliated metagabbro & - & $\begin{array}{r}42.9 \\
\mathrm{a}(42.5)\end{array}$ & 43.0 & 38.3 & 18.7 & 0.50 & 0.41 & 2.7 & 51.9 & 45.4 & 0.24 & 0.75 \\
\hline$-3 \mathrm{D}-1,7-11$ & - & 43.6 & & & & & & & & & & \\
\hline \multirow[t]{2}{*}{$\begin{array}{l}\text { Foliated } \\
\text { amphibole gabbro }\end{array}$} & & 41.3 & & & & & & & & & & \\
\hline & & $(66.1)$ & & & & & & & & & & \\
\hline$-16 R-5,47-51$ & 80.7 & 65.3 & 45.3 & 47.1 & 7.6 & 0.61 & 0.17 & & & & & \\
\hline \multirow[t]{4}{*}{ Olivine gabbro } & 66.9 & 40.6 & 51.0 & 8.4 & 0.66 & 0.11 & & & & & & \\
\hline & & & 47.0 & 46.6 & 6.4 & 0.44 & 0.17 & & & & & \\
\hline & & & 47.4 & 46.2 & 6.5 & 0.61 & 0.17 & & & & & \\
\hline & & & 45.3 & 47.1 & 7.6 & 0.59 & 0.16 & & & & & \\
\hline$-23 \mathrm{R}-1,46-53$ & & 40.4 & 42.2 & 39.7 & 18.1 & 0.70 & 0.32 & 3.2 & 61.4 & 35.5 & 0.34 & 0.62 \\
\hline \multicolumn{13}{|l|}{ Gabbronorite } \\
\hline & & $(63.1)$ & & & & & & & & & & \\
\hline & 67.0 & 63.8 & 45.1 & 45.4 & 9.5 & 0.73 & 0.22 & & & & & \\
\hline \multirow[t]{3}{*}{ Gabbro } & & 62.3 & 42.5 & 43.7 & 13.8 & 0.88 & 0.29 & & & & & \\
\hline & & & 46.7 & 44.7 & 8.6 & 0.55 & 0.21 & & & & & \\
\hline & & & 40.9 & 47.9 & 11.2 & 0.55 & 0.20 & 15.8 & 67.0 & 17.2 & 0.29 & 0.36 \\
\hline \multirow{6}{*}{ Oxide gabbro } & - & - & - & - & - & - & - & - & - & - & - & - \\
\hline & & & 43.4 & 41.2 & 15.3 & 1.02 & 0.26 & & & & & \\
\hline & 50.8 & 41.9 & 38.3 & 19.9 & 0.63 & 0.38 & & & & & & \\
\hline & & & 30.9 & 43.8 & 25.2 & 0.46 & 0.47 & 2.8 & 57.5 & 39.8 & 0.35 & 0.67 \\
\hline & & & 25.9 & 56.0 & 18.1 & 0.46 & 0.30 & & & & & \\
\hline & $(60.6)$ & $(45.9)$ & & & & & & & & & & \\
\hline$-41 R-4,68-70$ & 61.4 & 45.7 & 43.3 & 42.3 & 14.4 & 0.69 & 0.32 & 2.0 & 67.0 & 31.0 & 0.21 & 0.48 \\
\hline Olivine gabbro & 59.3 & 47.0 & 43.7 & 41.8 & 14.7 & 0.60 & 0.33 & 2.1 & 67.0 & 30.9 & 0.14 & 0.59 \\
\hline & 59.9 & 44.2 & 44.2 & 41.2 & 14.6 & 0.68 & 0.26 & & & & & \\
\hline & 61.3 & 46.9 & 45.5 & 40.6 & 13.9 & 0.83 & 0.28 & & & & & \\
\hline & 61.4 & 45.9 & 42.6 & 40.7 & 16.6 & 0.82 & 0.33 & & & & & \\
\hline & 61.1 & & & & & & & 1.8 & 65.4 & 32.7 & 0.44 & 0.58 \\
\hline$-44 R-2,6-8$ & & 38.7 & 43.6 & 39.0 & 17.5 & 0.80 & 0.36 & 2.4 & 62.5 & 35.2 & 0.29 & 0.75 \\
\hline & & 40.1 & & & & & & 2.7 & 60.4 & 36.9 & 0.41 & 0.71 \\
\hline & & & & & & & & 10.5 & 55.2 & 34.3 & 0.34 & 0.73 \\
\hline & & (37.7) & & & & & & & & & & \\
\hline$-47 R-2,31-36$ & & 36.7 & 40.6 & 40.0 & 19.4 & 0.81 & 0.36 & & & & & \\
\hline Oxide-rich & & 35.8 & 43.2 & 38.8 & 17.6 & 0.56 & 0.40 & & & & & \\
\hline gabbro & & 40.6 & 38.6 & 42.5 & 18.9 & 0.72 & 0.42 & & & & & \\
\hline$(>50 \% \mathrm{Il}+\mathrm{Mt})$ & & 37.6 & & & & & & & & & & \\
\hline $118-735 \mathrm{~B}-49 \mathrm{R}-2,89-91$ & Fo(\%) & An(\%) & Wo & En & Fs & $\mathrm{TiO}_{2}$ & $\mathrm{MnO}$ & Wo & En & Fs & $\mathrm{TiO}_{2}$ & $\mathrm{MnO}$ \\
\hline & & $(35.9)$ & & & & & & & & & & \\
\hline & & 35.1 & 43.4 & 40.3 & 16.3 & 0.44 & 0.32 & 4.8 & 56.2 & 39.0 & 0.30 & 0.60 \\
\hline & & 36.6 & 43.6 & 40.1 & 16.3 & 0.40 & 0.37 & 5.7 & 57.3 & 37.0 & 0.28 & 0.60 \\
\hline & & & 41.5 & 39.8 & 18.7 & 0.76 & 0.40 & 2.0 & 58.2 & 39.3 & 0.29 & 0.75 \\
\hline & & & 41.1 & 38.9 & 18.0 & 0.71 & 0.36 & & & & & \\
\hline & & (33.3) & & & & & & & & & & \\
\hline$-52 R-4,78-88$ & 36.6 & 33.3 & 26.3 & 40.5 & 33.2 & 0.48 & 0.56 & & & & & \\
\hline & & 33.3 & 43.2 & 34.5 & 22.4 & 0.69 & 0.49 & & & & & \\
\hline & & & 34.7 & 37.7 & 27.5 & 0.63 & 0.55 & & & & & \\
\hline & & & 41.9 & 35.4 & 22.7 & 0.54 & 0.51 & & & & & \\
\hline & & (31.4) & & & & & & & & & & \\
\hline$-53 R-4,78-88$ & & 34.3 & 43.4 & 35.2 & 21.5 & 0.67 & 0.44 & & & & & \\
\hline Oxide gabbro & & 28.4 & & & & & & & & & & \\
\hline 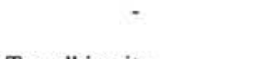 & - & $(20.2)$ & - & - & - & - & - & - & - & - & - & - \\
\hline Trondhjemite & & 22.7 & 44.0 & 33.9 & 22.1 & 0.10 & 0.56 & 2.6 & 43.6 & 53.8 & 0.09 & 1.05 \\
\hline & & 17.2 & 44.0 & 32.1 & 23.8 & 0.15 & 0.48 & 2.5 & 40.8 & 56.7 & 0.09 & 0.90 \\
\hline & & 20.8 & & & & & & 2.3 & 42.0 & 55.8 & 0.09 & 1.00 \\
\hline & $(38.0)$ & $(34.1)$ & & & & & & & & & & \\
\hline$-55 \mathrm{R}-2,110-120$ & 36.3 & 33.3 & 42.0 & 33.4 & 24.6 & 0.27 & 0.50 & & & & & \\
\hline Oxide gabbro & 39.7 & 34.9 & 40.7 & 34.7 & 24.7 & 0.51 & 0.45 & 24.6 & 40.0 & 35.4 & 0.47 & 0.70 \\
\hline & & & 42.6 & 34.9 & 27.5 & 0.57 & 0.49 & & & & & \\
\hline & & & 44.5 & 34.1 & 21.4 & 0.28 & 0.46 & & & & & \\
\hline$-69 R 4,138-145$ & 76.5 & 61.8 & 41.7 & 47.9 & 10.6 & 0.63 & 0.23 & & & & & \\
\hline Olivine gabbro & & & 48.3 & 42.8 & 10.9 & 0.99 & 0.21 & 2.2 & 75.3 & 22.5 & 0.47 & 0.44 \\
\hline
\end{tabular}


Table 2 (continued).

\begin{tabular}{|c|c|c|c|c|c|c|c|c|c|c|c|c|}
\hline \multirow{2}{*}{$\begin{array}{c}\text { Sample } \\
118-735 B-\end{array}$} & \multirow{2}{*}{$\begin{array}{c}\mathrm{OL}^{1} \\
\mathrm{Fo}(\%)\end{array}$} & \multirow{2}{*}{$\begin{array}{r}\text { PLAG }{ }^{1} \\
\text { An(\%) }\end{array}$} & \multicolumn{5}{|c|}{ Clnopyroxene } & \multicolumn{5}{|c|}{ Low-Ca pyroxene } \\
\hline & & & Wo & En & Fs & $\mathrm{TiO}_{2}$ & $\mathrm{MnO}$ & Wo & En & Fs & $\mathrm{TiO}_{2}$ & $\mathrm{MnO}$ \\
\hline $\begin{array}{l}-73 R 5,74-78 \\
\text { Oxide gabbro }\end{array}$ & & $\begin{array}{l}(33.7) \\
33.5 \\
33.9\end{array}$ & $\begin{array}{l}42.5 \\
43.6 \\
42.6\end{array}$ & $\begin{array}{l}38.9 \\
39.4 \\
36.3\end{array}$ & $\begin{array}{l}18.6 \\
16.9 \\
21.1\end{array}$ & $\begin{array}{l}0.63 \\
0.52 \\
0.28\end{array}$ & $\begin{array}{l}0.49 \\
0.38 \\
0.37\end{array}$ & 4.4 & 58.6 & 37.0 & 0.33 & 0.78 \\
\hline $\begin{array}{l}-74 \mathrm{R}-6,27-35 \\
\text { Oxide gabbro }\end{array}$ & & $\begin{array}{c}(39.3) \\
40.0 \\
37.7\end{array}$ & 40.8 & 39.3 & 18.9 & 0.62 & 0.36 & 3.1 & 59.5 & 37.4 & 0.70 & 0.84 \\
\hline $\begin{array}{l}-77 \mathrm{R}-4,70-72 \\
\text { Oxide gabbro } \\
\text { (cumulate) }\end{array}$ & $\begin{array}{c}(34.2) \\
34.0 \\
34.4\end{array}$ & $\begin{array}{l}(33.1) \\
34.5 \\
32.8 \\
32.2\end{array}$ & $\begin{array}{l}39.0 \\
42.9 \\
41.9 \\
33.2 \\
31.2\end{array}$ & $\begin{array}{l}37.5 \\
35.7 \\
36.0 \\
39.9 \\
37.6\end{array}$ & $\begin{array}{l}23.5 \\
21.4 \\
22.1 \\
26.9 \\
31.2\end{array}$ & $\begin{array}{l}0.55 \\
0.20 \\
0.21 \\
0.49 \\
0.40\end{array}$ & $\begin{array}{l}0.51 \\
0.44 \\
0.50 \\
0.55 \\
0.62\end{array}$ & 5.5 & 49.2 & 45.3 & 0.24 & 0.82 \\
\hline $\begin{array}{l}-79 \mathrm{R}-2,64-67 \\
\text { Oxide gabbro } \\
\text { (foliated) }\end{array}$ & & 33.0 & $\begin{array}{l}43.8 \\
44.4 \\
41.9\end{array}$ & $\begin{array}{l}33.6 \\
35.8 \\
34.3\end{array}$ & $\begin{array}{l}22.7 \\
19.8 \\
23.8\end{array}$ & $\begin{array}{l}0.57 \\
0.65 \\
0.45\end{array}$ & $\begin{array}{l}0.46 \\
0.43 \\
0.44\end{array}$ & & & & & \\
\hline $\begin{array}{l}-80 \text { R-7, } 56-65 \\
\text { Oxide gabbro }\end{array}$ & $\begin{array}{c}(40.6) \\
40.4 \\
40.4 \\
41.0\end{array}$ & $\begin{array}{c}(36.7) \\
36.0 \\
38.2 \\
35.9\end{array}$ & $\begin{array}{l}44.1 \\
42.4 \\
42.9 \\
41.1\end{array}$ & $\begin{array}{l}36.5 \\
38.0 \\
37.0 \\
37.6\end{array}$ & $\begin{array}{l}19.4 \\
19.6 \\
20.0 \\
21.3\end{array}$ & $\begin{array}{l}0.49 \\
0.45 \\
0.52 \\
0.46\end{array}$ & $\begin{array}{l}0.32 \\
0.30 \\
0.39 \\
0.43\end{array}$ & & & & & \\
\hline
\end{tabular}

${ }^{1}$ Averages in ( ).

rocks of Skaergaard and Thingmuli (ferrodiorites of the Upper Border Group and rhyodacites, respectively); many ilmenites have higher $\mathrm{MnO}$ contents, and the magnetites are considerably more aluminous.

The abundances of these minor elements were not greatly modified by subsolidus re-equilibration of the oxides. Ilmenites have no structural $\mathrm{Al}$ and thus could not have been a source for $\mathrm{Al}_{2} \mathrm{O}_{3}$ in intergrown magnetites. The $\mathrm{MgO}$ contents of both ilmenite and magnetite are extremely low, which reflects the compositions of both minerals before re-equilibration. There is not enough modal magnetite to have provided all the $\mathrm{MnO}$ to so much ilmenite during re-equilibration. Thus, these aspects of oxide-mineral compositions can be interpreted as the consequences of very low $\mathrm{MgO}$, high $\mathrm{MnO}$, and high $\mathrm{Al}_{2} \mathrm{O}_{3}$ abundances in the liquids from which the ilmenite and magnetite crystallized.

This is in accord with estimates from bulk compositions and clinopyroxenes, but comparison to Skaergaard suggests that the oxide minerals actually crystallized from liquids having even lower $\mathrm{Mg \# s}$ than those that produced the silicates in the same rocks. Similarly, the high $\mathrm{MnO}$ abundances in the ilmenites suggest crystallization from extremely ironrich liquids. There is no question that the oxides crystallized from liquids more evolved than the ferroandesites and dacites of the Galapagos Spreading Center and Thingmuli, despite the similar range in Mg\#s implied by silicates. The Hole 735B oxide minerals evidently crystallized from liquids at the end of an extended course of high-iron differentiation, from liquids that were not siliceous in composition. The compositions of ilmenite and magnetite also strengthen the impression, inferred from textural relations, that they are foreign to the rocks now hosting them; they crystallized from extremely fractionated liquids that were injected, or introduced, into somewhat less evolved crystal cumulates from some other part of the crystallizing mass of rock. A process of physical reorganization of highly differentiated molten material took place, abetted by brittle/ductile deformation occurring at the same time.

\section{Sulfides}

Globular sulfides associated with $\mathrm{Fe}-\mathrm{Ti}$ oxides in Hole 735B gabbros are pyrite or pyrrhotite with subordinate chalcopyrite. The iron sulfides have little $\mathrm{Cu}, \mathrm{Ni}$, or $\mathrm{Zn}$ (Table 4); the chalcopyrites also have low abundances of $\mathrm{Ni}$ and $\mathrm{Zn}$. These minerals are the crystallization products of almost pure $\mathrm{Fe}-\mathrm{Cu}-\mathrm{S}$ immiscible liquids, and their phase relations can be considered in terms of these three components.

The two most puzzling aspects of these globular sulfides are (1) their sheer abundance in oxide concentrates; and (2) the high proportion of chalcopyrite within them. These points are underscored by consideration of what is known about sulfide segregation in abyssal tholeiites.

Primitive (magnesian) abyssal tholeiites studied from the North Atlantic and eastern Pacific commonly contain sulfide globules in glass consisting of two phases-Mss (monoclinic solid solution mainly of $\mathrm{Fe}$ and $\mathrm{Ni}$, with lesser $\mathrm{Cu}$ ) and Iss (intermediate solid solution of $\mathrm{Fe}$ and $\mathrm{Cu}$, with lesser $\mathrm{Ni}$ ) (Mathez, 1976, 1980; Czamanske and Moore, 1977; Francis, 1980). Abundances of sulfur in these primitive glasses are about 950 to $1050 \mathrm{ppm}$ (Fig. 11).

During the course of differentiation toward ferrobasalt liquid compositions, immiscible sulfide segregation extracts S from the silicate melt, but this is more than compensated by silicate mineral fractionation. Thus, overall $\mathrm{S}$ abundances increase in residual liquids to about 1800 to $2000 \mathrm{ppm}$ in ferrobasalts. Simultaneously, Ni is depleted chiefly by olivine fractionation, and $\mathrm{Cu}$ is extracted by the sulfides. This $\mathrm{Ni}$ diminishes from perhaps $200 \mathrm{ppm}$ and $\mathrm{Cu}$ from nearly $100 \mathrm{ppm}$ both to values of about $40 \mathrm{ppm}$ in ferrobasalts (J. Natland, unpubl. data). Sulfide globules in glasses of such rocks contain little of either $\mathrm{Cu}$ or $\mathrm{Ni}$. Upon subsolidus recrystallization, they might produce no more than about $3 \%$ chalcopyrite.

Perfit and Fornari (1983) further showed that crystallization of $\mathrm{Fe}$ - Ti oxides exerts a strong control on the segregation of sulfides in ferroandesite and andesite liquids, because of the reduction in $\mathrm{FeO}$ in those liquids. Mathez (1976) argued that S 
Table 3. Oxide minerals.

\begin{tabular}{|c|c|c|c|c|c|c|c|c|c|}
\hline \multirow{2}{*}{$\begin{array}{c}\text { Sample } \\
118-735 B\end{array}$} & \multirow[b]{2}{*}{$\mathrm{TiO}_{2}$} & \multirow[b]{2}{*}{$\mathrm{Al}_{2} \mathrm{O}_{3}$} & \multirow[b]{2}{*}{$\mathrm{Fe}_{2} \mathrm{O}_{3}$} & \multirow[b]{2}{*}{$\mathrm{FeO}$} & \multirow[b]{2}{*}{$\mathrm{MnO}$} & \multirow[b]{2}{*}{$\mathrm{MgO}$} & \multicolumn{3}{|c|}{ Stormer (1983) } \\
\hline & & & & & & & $\Sigma$ & $X^{\prime}$ usp & $\mathrm{X}^{\prime} \mathrm{ilm}$ \\
\hline \multirow[t]{3}{*}{$-2 \mathrm{D}-1,145-179$} & 51.22 & 0.00 & 3.84 & 43.18 & 0.69 & 1.21 & 100.14 & \multirow{3}{*}{0.266} & 0.96 \\
\hline & 7.93 & 2.76 & 46.45 & 35.93 & 0.34 & 0.43 & 93.68 & & \\
\hline & 50.08 & 0.00 & 3.84 & 43.52 & 1.45 & 0.02 & 98.91 & & 0.96 \\
\hline \multirow[t]{2}{*}{$-23 R-1,46-63$} & 2.66 & 2.27 & 60.56 & 32.97 & 0.16 & 0.25 & 98.87 & \multirow[t]{2}{*}{0.835} & \\
\hline & 50.39 & 0.00 & 4.98 & 41.86 & 1.15 & 1.28 & 99.66 & & 0.95 \\
\hline \multirow[t]{3}{*}{$-41 \mathrm{R}-4,68-70$} & 48.58 & 0.00 & 6.00 & 39.66 & 1.09 & 1.62 & 96.95 & \multirow[b]{3}{*}{0.061} & 0.93 \\
\hline & 48.23 & 0.00 & 8.24 & 39.32 & 0.84 & 1.77 & 98.40 & & 0.91 \\
\hline & 1.99 & 1.21 & 62.55 & 32.14 & 0.19 & 0.11 & 98.19 & & \\
\hline \multirow[t]{4}{*}{$-44 R-2,6-8$} & 1.15 & 1.77 & 64.96 & 32.05 & 0.08 & 0.25 & 100.29 & \multirow[t]{2}{*}{0.035} & \\
\hline & 49.82 & 0.00 & 3.17 & 48.87 & 1.25 & 0.36 & 99.49 & & 0.953 \\
\hline & 18.37 & 2.52 & 29.56 & 46.83 & 0.60 & 0.40 & 98.27 & \multirow[t]{2}{*}{0.571} & \\
\hline & 49.64 & 0.00 & 7.29 & 40.06 & 0.89 & 2.07 & 99.94 & & 0.92 \\
\hline$-47 \mathrm{R}-2,31-36$ & 49.88 & 0.00 & 5.52 & 41.38 & 0.73 & 1.53 & 99.03 & & 0.94 \\
\hline \multirow[t]{4}{*}{$-49 \mathrm{R}-2,89-91$} & 4.94 & 2.85 & 55.59 & 35.08 & 0.22 & 0.34 & 99.01 & \multirow[t]{2}{*}{0.158} & \\
\hline & 51.57 & 0.00 & 2.97 & 44.36 & 1.28 & 0.41 & 100.62 & & 0.971 \\
\hline & 6.06 & 2.90 & 52.49 & 36.03 & 0.19 & 0.17 & 97.84 & \multirow[t]{2}{*}{0.198} & \\
\hline & 51.04 & 0.00 & 3.75 & 44.45 & 0.73 & 0.37 & 100.33 & & 0.96 \\
\hline \multirow[t]{3}{*}{$-52 R-4,69-71$} & 6.45 & 2.03 & 51.88 & 35.96 & 0.27 & 0.08 & 96.67 & 0.206 & \\
\hline & 49.57 & 0.00 & 5.02 & 42.09 & 0.77 & 0.93 & 98.38 & & 0.95 \\
\hline & 50.02 & 0.00 & 4.77 & 42.48 & 0.78 & 0.93 & 98.98 & & 0.95 \\
\hline$-53 R-4,68-78$ & 4.42 & 0.45 & 57.12 & 33.79 & 0.17 & 0.02 & 95.91 & 0.135 & \\
\hline & 49.15 & 0.00 & 6.13 & 42.82 & 1.30 & 0.03 & 99.43 & & 0.94 \\
\hline & 50.19 & 0.00 & 4.85 & 43.92 & 0.79 & 0.21 & 99.96 & & 0.95 \\
\hline & 5.50 & 0.88 & 55.14 & 35.13 & 0.23 & 0.00 & 96.88 & 0.169 & \\
\hline$-55 \mathrm{R}-2$ & 8.49 & 3.68 & 48.64 & 38.74 & 0.34 & 0.33 & 100.22 & 0.276 & \\
\hline & 51.17 & 0.00 & 4.05 & 43.33 & 0.88 & 0.98 & 100.01 & & 0.96 \\
\hline$-69 R-4,138-145$ & 50.47 & 0.00 & 7.21 & 37.51 & 0.74 & 3.98 & 99.91 & & 0.92 \\
\hline$-73 R-5,74-78$ & 0.78 & 0.74 & 66.15 & 31.57 & 0.11 & 0.01 & 99.36 & 0.023 & \\
\hline & 49.78 & 0.02 & 6.09 & 43.02 & 1.21 & 0.29 & 100.38 & & 0.94 \\
\hline & 2.77 & 0.93 & 63.80 & 33.85 & 0.23 & 0.05 & 101.73 & 0.081 & \\
\hline & 48.29 & 0.00 & 7.91 & 41.71 & 1.43 & 0.12 & 99.35 & & 0.92 \\
\hline$-74 R-6,27-35$ & 3.11 & 3.98 & 57.67 & 34.26 & 0.18 & 0.02 & 99.22 & 0.107 & \\
\hline & 1.83 & 2.50 & 59.83 & 31.72 & 0.10 & 0.10 & 96.08 & 0.057 & \\
\hline & 49.48 & 0.00 & 5.19 & 42.96 & 1.31 & 0.12 & 99.06 & & 0.94 \\
\hline$-77 R-4,70-72$ & 14.79 & 3.15 & 36.02 & 44.07 & 0.86 & 0.05 & 98.96 & 0.477 & \\
\hline & 2.76 & 1.43 & 60.00 & 32.76 & 0.16 & 0.01 & 97.11 & 0.087 & \\
\hline & 49.86 & 0.00 & 4.68 & 42.88 & 1.50 & 0.25 & 99.17 & & 0.95 \\
\hline & 9.35 & 2.78 & 47.55 & 39.61 & 0.30 & 0.16 & 99.75 & 0.297 & \\
\hline & 50.78 & 0.00 & 4.14 & 43.83 & 0.87 & 0.53 & 100.13 & & 0.96 \\
\hline$-79 \mathrm{R}-2,64-67$ & 13.14 & 0.90 & 41.79 & 41.03 & 1.44 & 0.33 & 98.63 & 0.382 & \\
\hline & 50.36 & 0.00 & 3.49 & 43.50 & 0.71 & 0.57 & 98.63 & & 0.96 \\
\hline & 3.08 & 11.85 & 49.69 & 35.03 & 0.16 & 0.75 & 100.57 & 0.140 & \\
\hline$-80 R-7,56-65$ & 5.77 & 2.85 & 51.53 & 34.95 & 0.21 & 0.24 & 95.55 & 0.193 & \\
\hline & 50.82 & 0.00 & 3.21 & 43.12 & 0.59 & 1.12 & 98.86 & & 0.96 \\
\hline & 51.14 & 0.00 & 2.63 & 44.52 & 0.89 & 0.32 & 99.49 & & 0.94 \\
\hline
\end{tabular}

is bonded to divalent $\mathrm{Fe}$ in molten abyssal tholeiite and that consumption of oxygen by crystallization of oxide minerals suddenly forces sulfide segregation to buffer oxygen fugacities. Whatever the case, $\mathrm{S}$ abundances in these intermediate liquids are abruptly reduced to values of less than $800 \mathrm{ppm}$, and they continue to decrease to less than $400 \mathrm{ppm}$ as differentiates approach dacitic compositions (Fig. 15). This predicts that sulfide minerals will be concentrated in cumulates produced by liquids with $\mathrm{Mg \# s}$ of about 0.3 to 0.4 .

The gabbros from Hole 735B show the expected dependency of sulfide segregation on the crystallization of oxides, but judging from the compositions of both associated silicates and oxides, the acme of sulfide segregation was reached a great deal later, in more evolved, low-temperature, iron-rich liquids. Moreover, the proportion of chalcopyrite within the sulfide globules is much more than $3 \%$ (more like 10\%-25\%).
Part of the explanation for this has already been mentioned. Parental abyssal tholeiites were undersaturated in sulfur. Glass compositions (Table 1; Fig. 15) indicate that sulfide segregation did not commence until ferrobasalt compositions with $\mathrm{Mg} \# \mathrm{~s}<0.4$ were reached. In addition, however, even after sulfide saturation was achieved, crystallization of oxides, particularly magnetite, was also greatly deferred. The liquids, following a course of extended high-iron fractionation, continued to increase in S contents (even though some sulfides were now segregating). But because of the late onset of sulfide saturation, abundances of copper were not so greatly diminished, although reduction of $\mathrm{Ni}$ in the liquids was virtually complete because of olivine crystallization. Thus, the observed sulfide globules are Ni-poor, yet they have abundant chalcopyrite.

Subsolidus recrystallization produced pyrite-pyrrhotitechalcopyrite assemblages at or about $742^{\circ} \mathrm{C}$, attended by 
Table 4. Compositions of sulfides.

\begin{tabular}{|c|c|c|c|c|c|c|c|c|}
\hline & Sulfide $^{\mathrm{a}}$ & $\mathrm{Fe}$ & $\mathrm{Cu}$ & $\mathrm{Ni}$ & Co & $\mathrm{Zn}$ & $\mathrm{S}$ & $\Sigma$ \\
\hline \multirow[t]{4}{*}{$23 \mathrm{R}-1,46-53$} & PY & 47.1 & 0.16 & 0.28 & 0.17 & 0.06 & 53.5 & 101.2 \\
\hline & PY & 46.2 & 0.16 & 1.1 & 0.14 & 0.05 & 53.6 & 101.2 \\
\hline & CCP & 30.6 & 33.7 & 0.03 & 0.04 & 0.11 & 34.7 & 99.2 \\
\hline & PY & 47.1 & 0.03 & 0.47 & 0.29 & 0.05 & 54.0 & 102.0 \\
\hline \multirow[t]{7}{*}{$44 R-2,6-8$} & PY & 45.4 & 0.01 & 0.20 & 0.26 & 0.03 & 53.7 & 99.6 \\
\hline & PY & 46.6 & 0.02 & 0.26 & 0.25 & 0.05 & 53.6 & 100.7 \\
\hline & $\mathrm{CCP}$ & 30.7 & 33.4 & 0.04 & 0.06 & 0.05 & 35.7 & 99.9 \\
\hline & Iss & 40.7 & 10.5 & 0.27 & 0.29 & 0.02 & 48.1 & 99.8 \\
\hline & Iss & 43.0 & 8.3 & 0.33 & 0.09 & 0.03 & 47.3 & 99.1 \\
\hline & $\mathrm{CCP}$ & 30.6 & 33.4 & 0.00 & 0.04 & 0.04 & 36.0 & 100.1 \\
\hline & PY & 44.9 & 0.19 & 0.58 & 0.37 & 0.01 & 51.2 & 97.2 \\
\hline \multirow[t]{5}{*}{$49 R 2,89-91$} & PY & 44.0 & 0.07 & 0.25 & 0.40 & 0.00 & 51.8 & 96.6 \\
\hline & PY & 46.4 & 0.20 & 0.55 & 0.59 & 0.01 & 53.1 & 100.9 \\
\hline & $\mathrm{CCP}$ & 31.5 & 32.6 & 0.02 & 0.06 & 0.04 & 35.6 & 99.9 \\
\hline & $\mathrm{PO}$ & 59.9 & 0.00 & 0.14 & 0.30 & 0.02 & 39.6 & 100.0 \\
\hline & $\mathrm{CCP}$ & 30.5 & 33.2 & 0.02 & 0.02 & 0.04 & 36.1 & 99.8 \\
\hline $52 \mathrm{R}-4,69-71$ & PY & 47.0 & 0.01 & 0.03 & 0.24 & 0.06 & 52.7 & 99.1 \\
\hline \multirow[t]{2}{*}{$53 R-4,78-88$} & CCP & 29.5 & 31.5 & 0.00 & 0.03 & 0.04 & 36.1 & 97.2 \\
\hline & PY & 45.8 & 0.07 & 0.07 & 0.26 & 0.00 & 52.9 & 99.1 \\
\hline \multirow[t]{2}{*}{$69 \mathrm{R}-4,138-140$} & $\mathrm{PO}$ & 61.8 & 0.01 & 0.13 & 0.09 & 0.02 & 37.6 & 99.6 \\
\hline & $\mathrm{CCP}$ & 30.9 & 33.5 & 0.01 & 0.00 & 0.05 & 35.8 & 100.3 \\
\hline \multirow[t]{5}{*}{$73 \mathrm{R}-5,74-78$} & PY & 46.9 & 0.01 & 0.29 & 0.12 & 0.02 & 53.2 & 100.5 \\
\hline & PY & 45.5 & 1.55 & 0.41 & 0.16 & 0.00 & 51.4 & 99.0 \\
\hline & $\mathrm{CCP}$ & 33.2 & 33.2 & 0.14 & 0.31 & 0.01 & 35.6 & 99.9 \\
\hline & PY & 60.5 & 0.06 & 0.19 & 0.09 & 0.01 & 39.5 & 100.3 \\
\hline & $\mathrm{CCP}$ & 31.6 & 33.2 & 0.06 & 0.14 & 0.03 & 35.3 & 100.3 \\
\hline \multirow[t]{4}{*}{$74 \mathrm{R} 6,27-35$} & $\mathrm{PO}$ & 60.5 & 0.01 & 0.36 & 0.11 & 0.06 & 39.5 & 100.6 \\
\hline & $\mathrm{CCP}$ & 30.9 & 33.4 & 0.06 & 0.06 & 0.11 & 35.3 & 100.0 \\
\hline & $\mathrm{PO}$ & 60.6 & 0.07 & 0.20 & 0.25 & 0.04 & 39.5 & 100.7 \\
\hline & $\mathrm{CCP}$ & 30.9 & 33.4 & 0.06 & 0.06 & 0.11 & 35.3 & 100.0 \\
\hline \multirow[t]{3}{*}{$79 R-2,64-68$} & $\mathrm{PO}$ & 60.2 & 0.00 & 0.17 & 0.16 & 0.06 & 39.4 & 100.0 \\
\hline & $\mathrm{CCP}$ & 30.5 & 32.9 & 0.02 & 0.06 & 0.02 & 35.4 & 98.9 \\
\hline & $\mathrm{PO}$ & 60.8 & 0.02 & 0.10 & 0.12 & 0.00 & 39.4 & 100.5 \\
\hline \multirow[t]{2}{*}{$80 \mathrm{R}-7,56-65$} & $\mathrm{PO}$ & 59.7 & 0.04 & 0.11 & 0.16 & 0.04 & 39.83 & 99.9 \\
\hline & $\mathrm{CCP}$ & 30.3 & 34.3 & 0.07 & 0.03 & 0.11 & 35.4 & 100.2 \\
\hline
\end{tabular}

release of molten sulfur (Barton and Skinner, 1979). This was readily dissolved in migrating fluids and either redeposited in veins elsewhere in the crust (Alt, this volume) or carried to vents on the seafloor.

\section{Summary of Mineralogical Relationships and Comparisons}

The mineralogy of gabbros from Hole 735B indicates that a trend of extended tholeiitic high-iron differentiation was followed by the liquids from which the gabbros crystallized. The sequence bears strong similarity to the Skaergaard Intrusion, particularly in having two intervals of olivine crystallization and closely comparable compositions of silicate minerals at similar stages of differentiation. Nevertheless, there are some important contrasts to Skaergaard. The most notable is the absence in the gabbros of Hole $735 \mathrm{~B}$ of extremely iron-rich and fairly siliceous ferrodiorites with their correspondingly iron-rich pyroxenes and olivines. Yet, oxide minerals in Hole $735 \mathrm{~B}$ gabbros evidently crystallized from liquids more evolved than did their counterparts at Skaergaard, and silicic trondhjemite was the end result of the differentiation process. The crystallization sequence was unlike that which produced differentiation toward silicic lavas at the Galapagos Spreading Center in that oxide minerals crystallized from considerably less magnesian liquids and could not have modified the liquid line of descent toward silica-rich compositions so soon.
At Hole 735B, a close connection existed between crystallization of oxide minerals and segregation of immiscible sulfides. By inference from the compositions of dredged basalt glasses (none of which are sulfide-saturated), sulfide segregation did not begin until fractionated ferrobasaltic liquid compositions were reached. Consequently, $\mathrm{Cu}$ was retained in fractionated melts to a very late stage; thus, chalcopyrite is abundant in sulfide globules in Hole 735B oxide gabbros.

\section{EVALUATION OF THE LIQUID LINE OF DESCENT}

Accurate statements about melt evolution, based on compositions of gabbroic rocks in layered intrusions, are often difficult to make because of uncertainties about the compositions of parental liquids, the volume of the rock mass crystallized, and the possibility that the intrusion may not have operated as a "closed" system. The latter point was brought home in a compelling way by the recent controversy over the Skaergaard Intrusion (Hunter and Sparks, 1987; McBirney and Naslund, 1990; Morse, 1990; Brooks and Nielson, 1990; Hunter and Sparks, 1990a, 1990b, and 1990c). A philosophical offshoot of that discussion is a concern about whether igneous differentiation in a putatively isolated environment in the crust behaves in a fundamentally different way than that in a magma hearth beneath an active volcano. Is there really a good correspondence between the compositions of eruptive liquids and the line of descent they would follow during the crystallization of an igneous intrusion such as Skaergaard? 


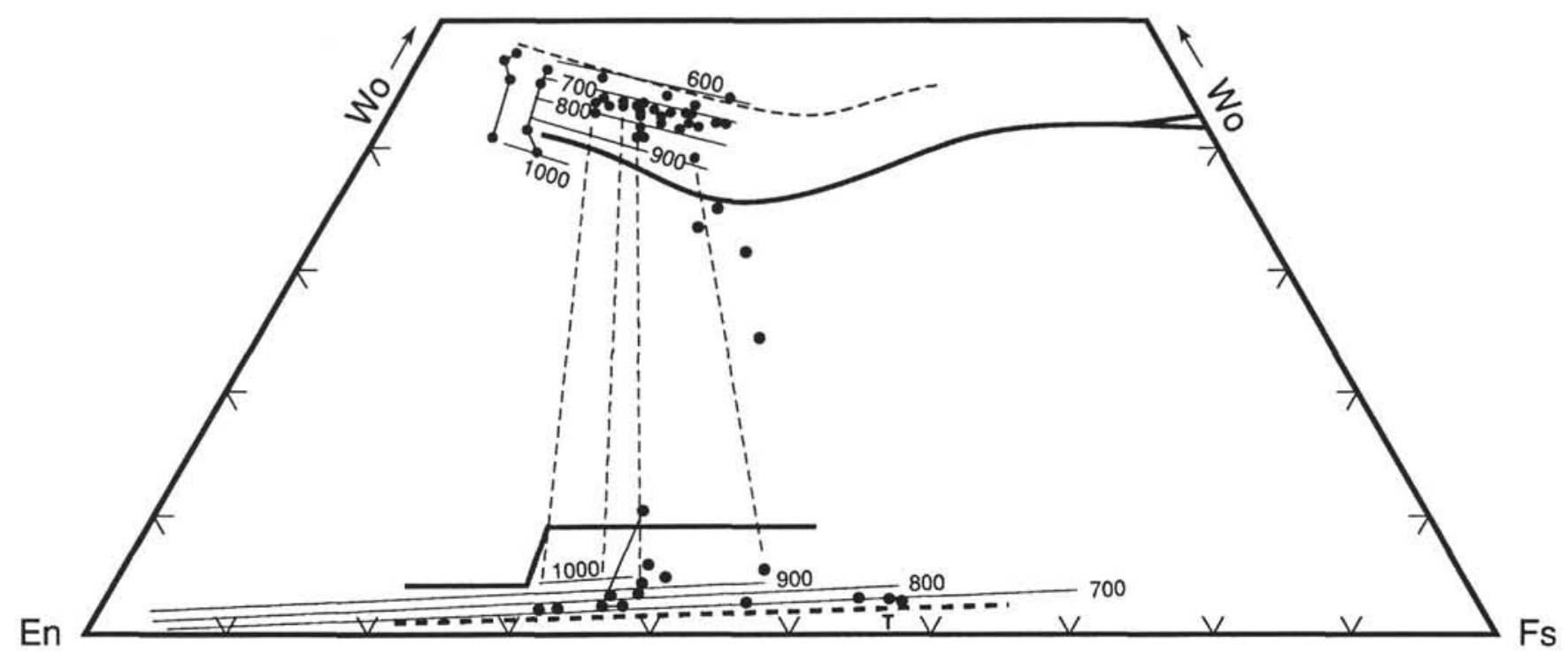

Figure 16. Proportions of Wo, En, and Fs in pyroxenes from Hole 735B, with the temperature grid of Lindsley (1989) superimposed. The bold solid and dashed lines = the Skaergaard solidus and subsolidus trends of Nwe (1976). The near-vertical dashed lines link coexisting low-Ca and high-Ca pyroxenes in selected samples. The thin, continuous, lines link compositions showing varying extents of subsolidus re-equilibration in individual samples.

The one advantage igneous petrologists have when dealing with the ocean crust is that liquid compositions, in the form of quenched margins to pillows and flows, are readily at hand. The great disadvantage is that the differentiating igneous systems are intrinsically "open" in the spreading environment, being recurrently injected with new magma from below, and expelling it from the top. There is no possibility of defining a volume of the differentiating mass, nor of stating the average composition of melt it held at any particular time. For the rock mass penetrated by Hole $735 \mathrm{~B}$, the additional complexities introduced by the diversity of parental magmas, multiple intrusive events, and differentiation during deformation preclude any type of massbalance approach to the liquid line of descent.

The approach we have taken so far is to use mineral/melt partitioning as a means of defining attributes of liquids responsible for particular gabbroic facies. There really is no other approach to take, but our approach involves one key assumption. This is that the minerals in the rocks (and by inference the rocks themselves) are close to the compositions they had when crystallizing from the melt, particularly as deduced from $\mathrm{Mg \# s}$ of clinopyroxene and olivine. Given that reactions between cumulus minerals and intercumulus trapped melt did not take place (because most intercumulus melt was squeezed from the rocks), the rocks should be nearly ideal assemblages of cotectic minerals, or as close to being such assemblages as nature is likely to provide. That is, they were before subsolidus recrystallization and alteration under hydrous conditions took place.

Consequently, there is room for uncertainty, and in the end, the question will remain as to how far from reality supposedly quantitative estimates happen to be. Perhaps the best that can be hoped is that the general tendencies, trends, and comparisons so revealed are valid. But again, the choice appears to be between making the attempt to specify a line of descent as quantitatively as possible, or not making it at all. The reader is invited to season the following with whatever grain of salt may seem appropriate.

\section{The Question of Liquid Immiscibility}

The occurrence of siliceous trondhjemite in oxide gabbros, with no intermediate compositions, suggests that two silicate liquids may have separated immiscibly. Immiscible formation of siliceous and very iron-rich liquids has been demonstrated as the outcome of extended high-iron differentiation in lunar samples (e.g., Roedder, 1979) and has been invoked to explain some Skaergaard granophyres (McBirney and Nakamura, 1974; McBirney, 1975), as well as siliceous rocks recovered (rarely) in the ocean crust, which resemble the plagiogranites of certain ophiolites in composition (Dixon and Rutherford, 1979). The chief concern of these studies has been the development of the siliceous liquids; thus, little attention has been given to the fate of the complementary, very iron-rich liquids produced during immiscible segregation. However, such liquids may have been important during the formation of oxide concentrates with sulfides in the gabbros of Hole 735B.

Figure 22 can be used to consider the course of ironenrichment differentiation for natural and experimental compositions. The experimental liquids of Dixon and Rutherford (1979), which attained immiscibility at very high iron concentrations, are compared to the calculated Skaergaard liquids of Wager (1960), to the compositions of highly fractionated glasses from the Galapagos Rift (Perfit and Fornari, 1983), and to a schematic estimate of what may have transpired during crystallization of the rocks of Hole 735B.

The experimental and calculated Skaergaard trends are similar. The data field for basalt glasses from Atlantis II Fracture Zone serves as a starting range of compositions for the liquid line of descent. It is displaced to lower $\mathrm{FeO}$ and $\mathrm{MgO}$ because the glasses have higher $\mathrm{TiO}_{2}$ and $\mathrm{Na}_{2} \mathrm{O}$ contents at given $\mathrm{Mg} \#$, with $\mathrm{Na}_{2} \mathrm{O}$ in particular being highly weighted when compositions are expressed as molecular proportions. This is merely an effect of closure.

A trend for $\mathrm{FeO}$ and $\mathrm{MgO}$ among liquids responsible for Hole $735 \mathrm{~B}$ gabbros is postulated simply by extrapolating from the field of glass analyses parallel to the calculated Skaergaard liquids and the experimental trend. This is justified by the mineralogical similarity to Skaergaard and by the fact of late crystallization of ilmenite and magnetite, which are the only minerals that could deflect the trend from a course of iron enrichment. 


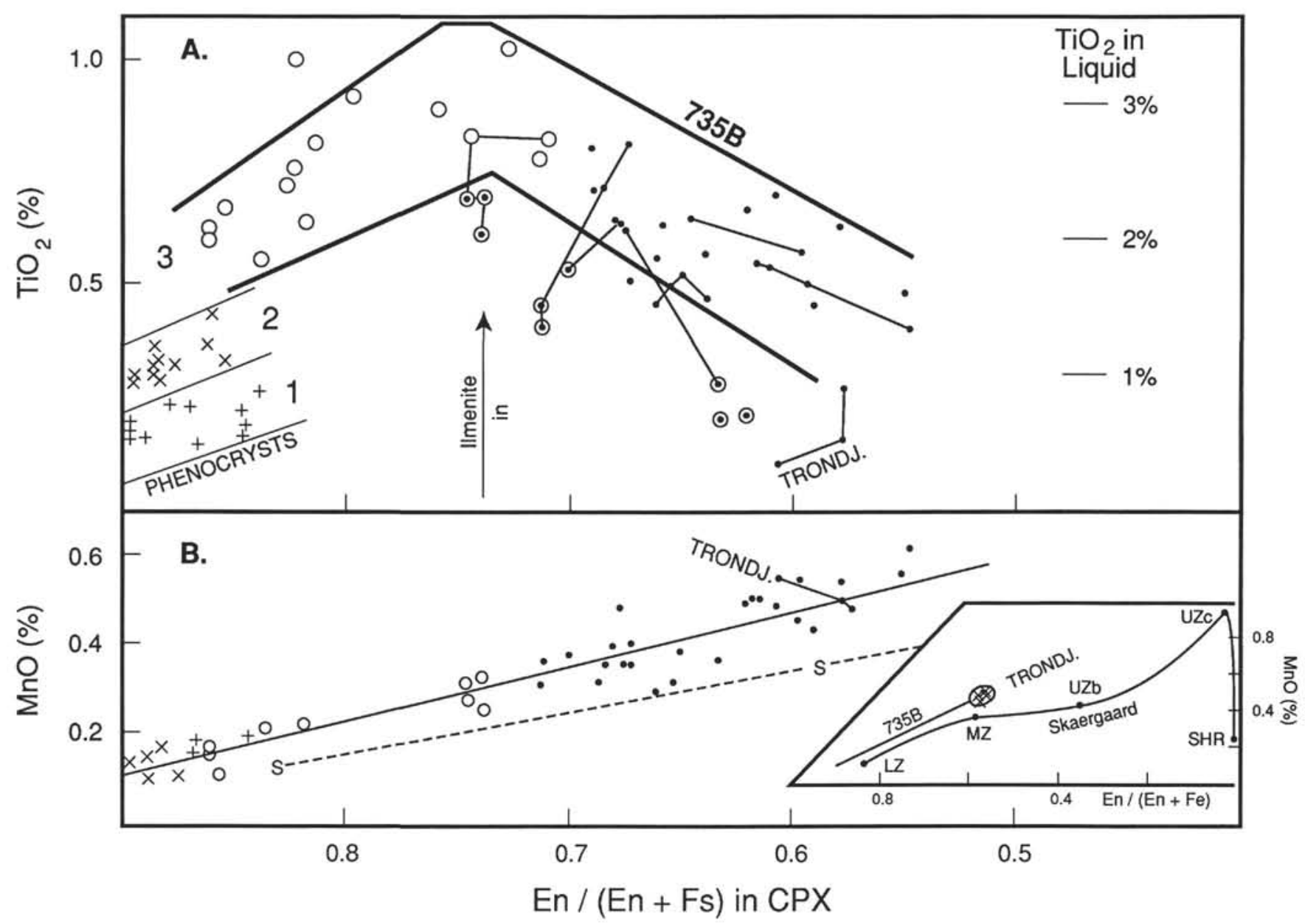

Figure 17. Minor oxide abundances in clinopyroxenes from Hole 735B. A. $\mathrm{TiO}_{2}$ vs. En/(En + Fs); B. MnO vs. (En/En + Fs). Symbols: plusses and crosses = phenocrysts in Indian Ocean Type 1 and Type 2 glasses (cf. Fig. 13); open circles = olivine gabbros; dots = oxide gabbros; and circled dots $=$ granular, recrystallized pyroxenes in olivine and oxide gabbros. Thin continuous lines link compositions from individual samples, including the trondhjemite (trondj). In $\mathrm{A}$, estimated $\mathrm{TiO}_{2}$ contents of liquids from which the pyroxenes crystallized are at the right. The maximum $\mathrm{TiO}_{2}$ content in the pyroxenes is taken to represent onset of ilmenite crystallization and consequent reduction in liquid $\mathrm{TiO}_{2}$ contents. In $\mathrm{B}$, Skaergaard clinopyroxenes (Wager and Brown, 1967) are linked by the dashed line. The inset, at a different scale, shows the Hole 735B trend in comparison to the full Skaergaard trend. The Skaergaard notation is as in the caption of Figure 5, plus LZ = Lower Zone, and SHR = Sandwich Horizon.

The two separate shaded fields block out estimated liquids responsible for the olivine gabbros and oxide-bearing gabbros, based on bulk compositions and mineral data. The field widths allow for uncertainty given by the width of the diagonally lined field of glass compositions. Temperature isopleths are based on olivine-melt equilibria (Roeder, 1974). Iron enrichment interrupted by oxide crystallization, as at the Galapagos Rift, is curtailed at about $\mathrm{FeO}(\mathrm{mol} \%)=12 \%$ (GSC trend in Fig. 22 ). Liquids not so interrupted will continue in a course of iron enrichment until $\mathrm{FeO}(\mathrm{mol} \%)$ contents reach $1 \%$ to $15 \%$ $(\mathrm{Mg} \# \mathrm{~s}=0.1-0.2)$, at which point they are appropriate for immiscible separation of two silicate liquids. Based on the compositions of olivines and clinopyrox nes, these conditions were reached by the liquids responsible for the Hole $735 \mathrm{~B}$ oxide-rich gabbros.

Iron-rich liquids formed immiscibly in the experiments of Dixon and Rutherford (1979) had $42 \%$ to $44 \% \mathrm{SiO}_{2}$ contents. Crystallization of such liquids will produce silicate assemblages dominated by pyroxenes (since feldspathic components segregate into the silica-rich liquid) together with oxide minerals. Plagioclases formed from the iron-rich liquids should be more anorthitic than those crystallizing just prior to immiscible separation, because of the preference of soda for the siliceous liquid (Naslund, 1983). This perhaps contributed to the downward inflection (at nearly constant normative An content) in the curve showing evolution of "cryptic" parameters in the bulk compositions of gabbros of Hole 735B (Fig. 5A).

Two aspects of mineral compositions also support immiscible separation during the late differentiation of these rocks. The first is the similar proportions of $\mathrm{Fe}, \mathrm{Mn}$, and $\mathrm{Mg}$ in clinopyroxenes of oxide gabbros and the trondhjemite (Fig. 17B), which imply the same proportions in corresponding liquids, assuming that distribution coefficients $\left(\mathrm{K}_{\mathrm{D}}\right.$ 's) are the same. Naslund (1983) showed experimentally that this is a consequence of immiscible segregation of siliceous and ironrich liquids at the culmination of high-iron differentiation. A continuous line of descent, influenced by earlier crystallization of oxide minerals, should show no such correspondence between ferrodiorites or siliceous granophyres and oxide-rich gabbroic cumulates (i.e., the late Skaergaard trend, shown in the inset to Fig. 10B). 


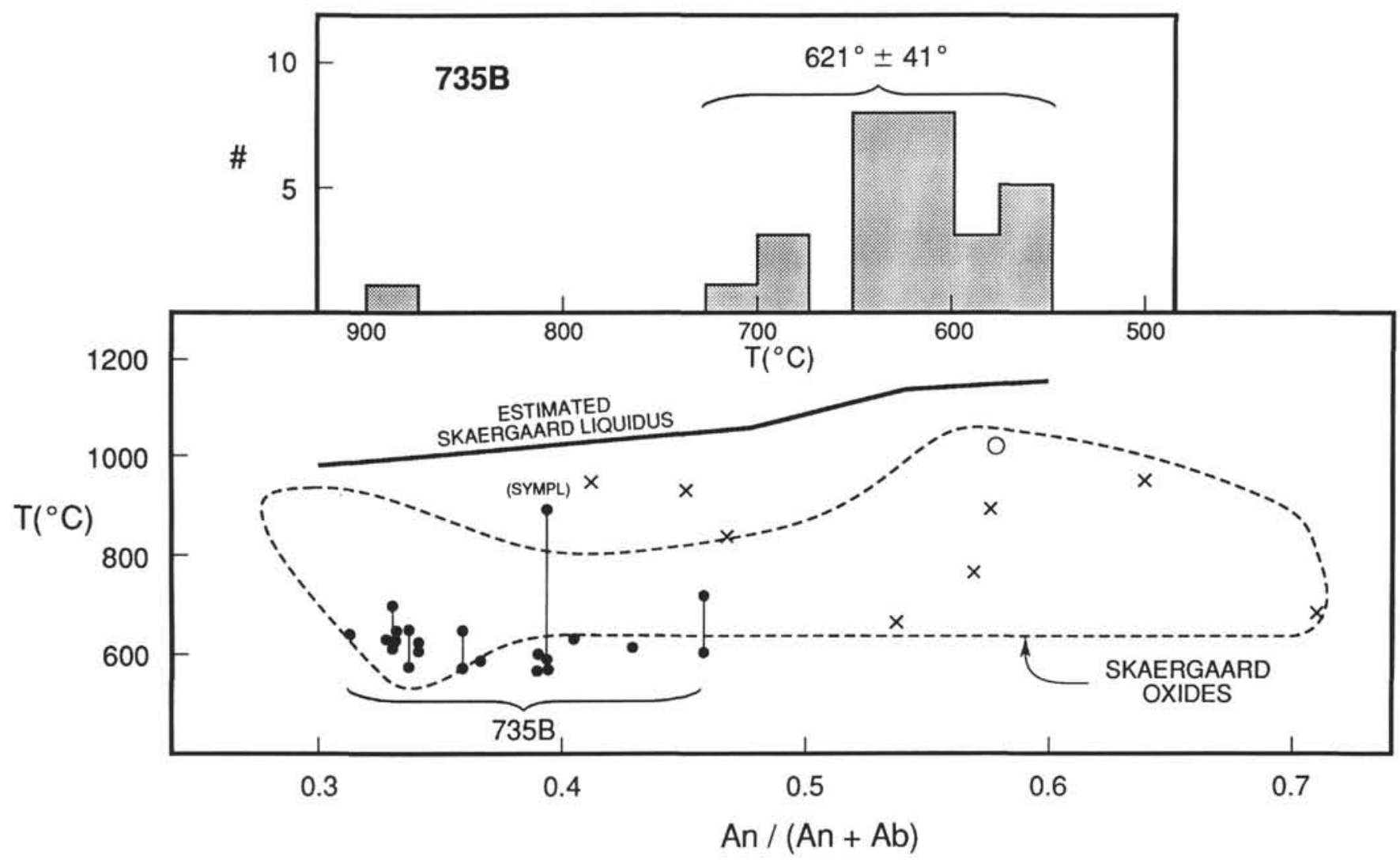

Figure 18. Temperatures calculated from coexisting ilmenite-magnetite pairs vs. average plagioclase composition in the same samples. Dots $=$ Hole 735B gabbros, crosses = abyssal gabbro xenoliths from Jasper Seamount (see text), and open circle = one andesite from the Galapagos Spreading Center (Perfit and Fornari, 1983). The estimated Skaergaard liquidus and the dashed field for Skaergaard oxides are from Naslund (1984). The upper diagram provides a histogram of temperatures calculated for Hole 735B.

Naslund (1983) also showed that iron-rich liquids formed by immiscible segregation are more aluminous than the liquids that existed just previously. This provides an explanation for the very aluminous compositions of low-MgO magnetites in oxide concentrates (Fig. 21).

\section{Melt Densities}

Figure 22 also depicts densities of melts produced during the course of high-iron differentiation, calculated for the experimental liquids using the procedure of Bottinga and Weill (1970). Before immiscible segregation, densities reached $2.9 \mathrm{~g} / \mathrm{cm}^{3}$. Afterward, siliceous liquids had low densities $\left(<2.5 \mathrm{~g} / \mathrm{cm}^{3}\right)$, whereas the iron- and titanium-rich liquids had high densities $\left(>3.0 \mathrm{~g} / \mathrm{cm}^{3}\right)$. Even prior to immiscible segregation, the last iron-rich liquids were sufficiently dense so that plagioclase must have been buoyant within them.

The high densities of the iron-rich liquids, especially those remaining after separation of immiscible siliceous liquids, offer a mechanism for producing the oxide concentrates of Hole 735B. Such liquids might have displaced both less-evolved crystal cumulates at the base of a magma chamber complex and, more than likely, their intercumulus liquids. They should have penetrated downward through crystal cumulates until porosity-limiting horizons were reached. This might have been accentuated by any concurrent process of deformation, allowing such liquids (or partly molten, oxide-rich, crystal mushes) to be injected along cracks or fissures that developed in the porous cumulates. By contrast, trondhjemitic liquids might have been buoyant and may have been expressed from the rocks upward along developing cracks and fissures. All this is simply to say that the densities of highly fractionated liquids must have played a strong role in the crosscutting relationships observed among oxide-rich gabbros and trondhjemites of Hole $735 \mathrm{~B}$.

\section{Further Evaluation of the Liquid Line of Descent}

Figure 22 specifies the likely $\mathrm{FeO}$ and $\mathrm{MgO}$ contents in $\mathrm{mol} \%$ as well as $\mathrm{Mg \# s}$ of liquids from which the gabbros of Hole 735B crystallized, assuming that extended high-iron differentiation took place and allowing for uncertainty in the range of compositions of initial parental liquids. This, together with inferences from mineral data and glass compositions, can be used to estimate abundances of other elements during various stages of the liquid line of descent.

In Figure 23, such estimates have been plotted vs. $\mathrm{Mg \#}$ for several oxides and $\mathrm{S}$. To simplify matters, abundances are referred to a median trend through the field of glass compositions in Figure 22 and extended to the most evolved gabbros (bold diagonal with broad arrows). This trend lies approximately between glass compositions from the west and east sides of the fracture zone (lined vertically and horizontally, respectively). Thus, the trend for $\mathrm{FeO}^{*}$ is taken directly from the median trend in Figure 22, but has been reconverted to weight percent. Iron enrichment is shown to occur up to the point of immiscible segregation of siliceous and iron-rich liquids, when the liquid $\mathrm{Mg \#}$ reached 0.175 , as inferred from the clinopyroxene compositions in the trondhjemite. At this point, the $\mathrm{FeO}^{*}$ content was $17.5 \%$. 


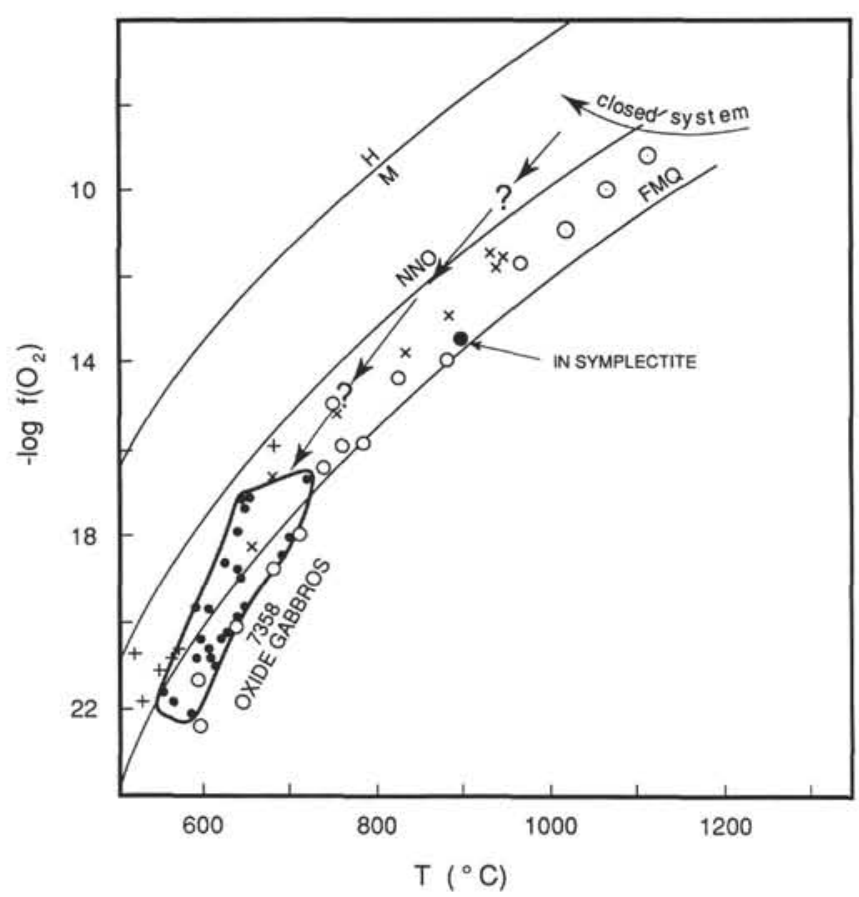

Figure 19. $\log \mathrm{f}\left(\mathrm{O}_{2}\right)$ vs. $\mathrm{T}\left({ }^{\circ} \mathrm{C}\right)$ calculated using oxide mineral pairs. Symbols are as in Figure 18, with the following additions: open circles = Skaergaard (Vincent and Phillips, 1957; Naslund, 1984). Plusses = other Ti-ferrogabbros from the Southwest Indian Ridge (J. Natland, unpubl. data). The trend labeled "closed system" is from Ghiorso and Carmichael (1985), with a possible link to recrystallized gabbros of Hole 735B indicated by the arrows. The curved lines give various buffers $(\mathrm{HM}=$ hematite-magnetite; $\mathrm{NNO}=$ nickel-nickel oxide; FMQ $=$ fayalite-magnetite-quartz.

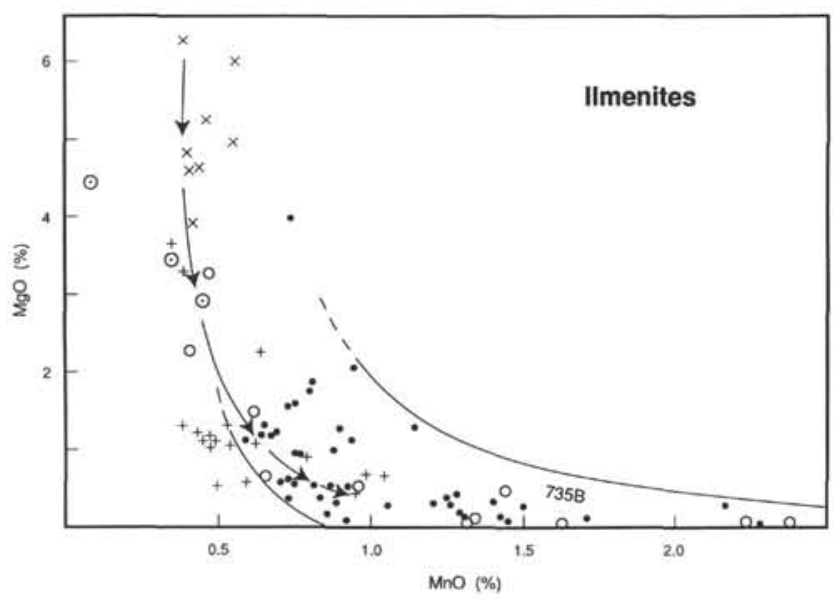

Figure $20 . \mathrm{MgO}$ vs. $\mathrm{MnO}$ in ilmenites of Hole 735B gabbros. Symbols are as in Figure 12, except for plusses, (Thingmuli volcano, Iceland; Carmichael, 1967). The arrowed trends indicate compositional changes resulting from crystallization differentiation in the volcanic suites and Skaergaard.

In similar fashion, $\mathrm{TiO}_{2}$ contents reached a maximum of $3.5 \%$ in liquid with $\mathrm{Mg} \#=0.35 \pm 0.05$, based on clinopyroxene data in Figure $17 \mathrm{~A}$. It diminished to about $2 \%$ because of ilmenite fractionation by the time immiscible separation occurred. $\mathrm{MnO}$ abundances clearly increased steadily, and here are presumed to have done so in proportion to $\mathrm{FeO}^{*}$.

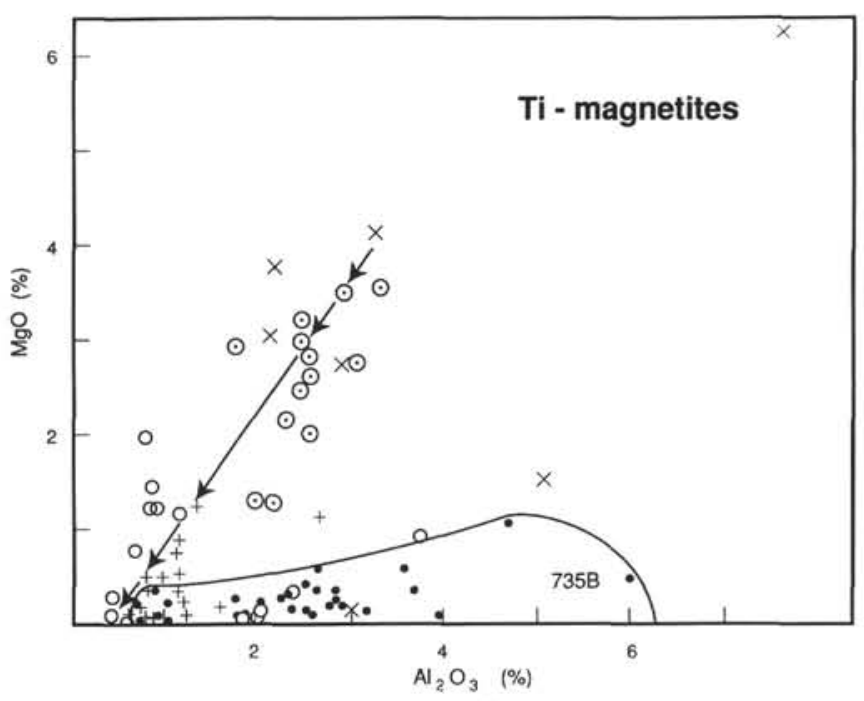

Figure $21 . \mathrm{MgO}$ vs. $\mathrm{Al}_{2} \mathrm{O}_{3}$ in titanomagnetites of Hole $735 \mathrm{~B}$ gabbros. Symbols and arrowed trends are as in Figure 20.

A separate procedure will be required to estimate the course of $\mathrm{P}_{2} \mathrm{O}_{5}$ variation. Phosphorus behaves as an almost ideally incompatible element during fractionation of silicate and oxide phases (Anderson and Greenland, 1970), until apatite saturation is reached. This can be inferred from Figure 24 , which depicts an experimentally determined apatite saturation relationship between $\mathrm{P}_{2} \mathrm{O}_{5}$ and $\mathrm{MgO}$ contents (Harrison and Watson, 1984). The trend for Hole 735B is interpolated from starting glass compositions to the apatite saturation surface, between trends for abyssal tholeiites from the Galapagos Spreading Center (Perfit et al., 1983; Juster et al., 1989) and alkalic series from seamounts off southern California and northern Mexico (Gee et al., in press; J. Natland, unpubl. data). Apatite saturation is achieved when $\mathrm{P}_{2} \mathrm{O}_{5}$ abundances are about $0.85 \%$ at $\mathrm{MgO}$ contents of about $2 \%$ (Mg\# from Fig. $22=0.23$ ).

Abundances of sulfur are inferred from relationships shown in Figure 15. Sulfur contents increased, beginning with abundances of about $800 \mathrm{ppm}$ in parental compositions to more than $1400 \mathrm{ppm}$ in the most evolved glasses obtained from the Atlantis II Fracture Zone by dredging (Table 1). Saturation of $\mathrm{S}$ at that point could not have been achieved because fractionation was dominated by plagioclase, producing an increase in S approximately parallel to the trend at saturation for glasses from the East Pacific Rise. However, with increasing proportion of clinopyroxene on the liquidus, iron enrichment was slowed, and the S trend (dashed line in Fig. 15) began to curve toward saturation. The point at which this occurred can be estimated by assuming that $\mathrm{S}$ continued to behave as an incompatible element, as does phosphorus with respect to fractionation, until sulfides began to segregate. An increase in $\mathrm{S}$ in proportion to $\mathrm{K}$ is given by the steep portion of the bold line in Figure 15, which is labeled "Rayleigh Fractionation." The slope of this portion of the trend is defined by the $\mathrm{P}_{2} \mathrm{O}_{5}-\mathrm{Mg}$ \# relationship in Figure 23, from which the $\mathrm{Fe}$ abundance of the liquid at $\mathrm{S}$ saturation was determined.

If, as argued earlier, $\mathrm{P}_{2} \mathrm{O}_{5}$ abundances were enhanced with respect to $\mathrm{S}$ as a consequence of reincorporation of trapped melts into intruding liquids, then the slope of this portion of the trend in Figure 15 will be less, and sulfide saturation occurred later, in more iron-rich liquids at lower temperature. Whenever sulfide saturation was achieved, $\mathrm{S}$ abundances are assumed then to have increased along an extrapolation of the 


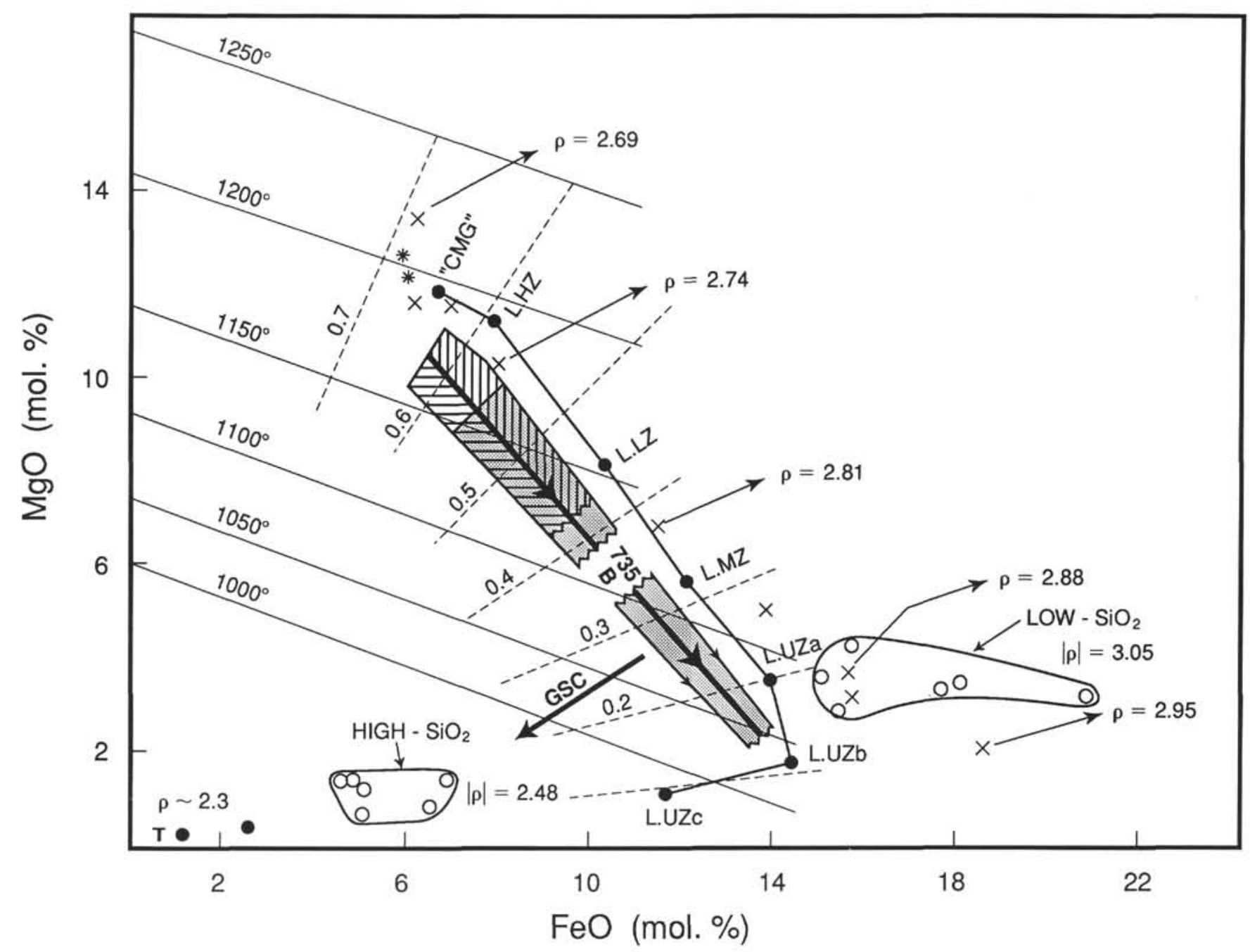

Figure 22. $\mathrm{FeO}$ ( $\mathrm{mol} \%$ ) vs. $\mathrm{MgO}$ (mol\%), illustrating the course of extended high-iron differentiation in natural glasses and experimental charges. Crosses and zeros indicate experimental glasses of Dixon and Rutherford (1979), produced from two starting materials (stars). Open dots = immiscible siliceous and iron-rich liquids produced at or near $1000^{\circ} \mathrm{C}$ in the experiments (separately circled). The bold dots linked by a continuous line represent calculated Skaergaard liquids for various stages of the Layered Series (Wager and Brown, 1967). Bold dots at or near 2\% FeO are for the Tinden granophyre at Skaergaard, plus T, the trondhjemite from Hole 735B. The diagonally striped field represents glasses from Atlantis II Fracture Zone (Table 1). The shaded fields are interpolated for Hole 735B liquids. GSC gives the general trend for the Galapagos Spreading Center, following early addition of titanomagnetite to the liquidus. Calculated anhydrous melt densities for the experimental liquids (method of Bottinga and Weill, 1970) are indicated.

$\mathrm{S}-\mathrm{Fe}$ trend for the East Pacific Rise in Figure 15, with this extrapolation giving the maximum $\mathrm{S}$ content of $2500 \mathrm{ppm}$ at the point of immiscible separation of two silicate liquids.

$\mathrm{P}_{2} \mathrm{O}_{5}$ abundances can be useful for specifying the percentage of crystallization from presumed parental liquids at critical points in the sequence of liquid differentiation. If parental liquids had $\mathrm{Mg} \#=0.70$, an estimated starting $\mathrm{P}_{2} \mathrm{O}_{5}$ concentration, based on glass compositions, is $0.15 \%$. Because $\mathrm{P}_{2} \mathrm{O}_{5}$ is so incompatible, its abundance during the early stages of silicate mineral fractionation were inversely proportional to the fraction of silicate liquid remaining. At $50 \%$ crystallization of silicates, $\mathrm{P}_{2} \mathrm{O}_{5}$ contents are doubled; at $75 \%$ they are doubled again. This assumes complete retention of $\mathrm{P}_{2} \mathrm{O}_{5}$ in the liquid (no residual melt porosity in cumulates). Comparison to the curve for $\mathrm{P}_{2} \mathrm{O}_{5}$ in Figure 23 indicates that both $\mathrm{S}$ saturation and addition of ilmenite to the liquids occurred nearly simultaneously (coincidentally?) at about $65 \%$ crystallization of silicate minerals from paren- tal liquid. Apatite saturation was achieved at just over $80 \%$ crystallization of the initial liquid.

Following this, residual liquids were assumed to follow the apatite saturation surface in Figure 24 until $\mathrm{MgO}$ contents decreased to levels appropriate for immiscible liquid separation $\left(0.65 \% \mathrm{P}_{2} \mathrm{O}_{5}\right.$ at $\left.\mathrm{MgO}=1.5 \%\right)$. The percentage of initial parental liquid crystallized when immiscible separation occurs is difficult to estimate unless phosphorus behaves as an incompatible element. Extrapolations of the curves defining $\mathrm{P}_{2} \mathrm{O}_{5}$ increases in Figures 23 and 24 suggest that $90 \%$ crystallization is a reasonable estimate.

Figures 15,22 , and 23 all provide comparisons of the estimated liquid evolution of the Skaergaard Intrusion with glass compositions from the Galapagos Spreading Center. For Skaergaard, $\mathrm{TiO}_{2}$ contents achieve a maximum at almost precisely the same point in the liquid evolution as for Hole $735 \mathrm{~B}$, and iron enrichment is considered to continue beyond this (Wager, 1960; Wager and Brown, 1967). Ilmenite and 
Ti-magnetite both join the liquidus assemblage earlier at the Galapagos Spreading Center, inhibiting iron enrichment there. $\mathrm{P}_{2} \mathrm{O}_{5}$ contents estimated for Skaergaard liquids closely follow the trend inferred for Hole $735 \mathrm{~B}$ in early stages, but are anomalously enriched in Upper Zone ferrodiorites and equivalent rocks of the Marginal Border Group. This is considered to indicate that different liquids, one phosphorus-poor, the other phosphorus-rich, separated into convecting cells of different density (Irvine, 1979; Naslund, 1984). The causes of $\mathrm{P}_{2} \mathrm{O}_{5}$ and other enrichments in the upper cell are uncertain, but they imply that estimates of percentage of crystallization (based on $\mathrm{P}_{2} \mathrm{O}_{5}$ contents) are unreliable for the corresponding portions of the Skaergaard.

The different courses of $\mathrm{S}$ evolution in the liquids at the Galapagos Spreading Center and inferred for Hole 735B (Figs. 15 and 23) are shown to indicate the contrasting role of oxide-mineral crystallization, particularly titanomagnetite. At the Galapagos Spreading Center, there was a decline in $\mathrm{S}$ concentrations following the addition of oxide minerals to the liquidus, even though $\mathrm{S}$ contents were higher than in corresponding liquids at Hole $735 \mathrm{~B}$ (with the same $\mathrm{Mg \# ).} \mathrm{In} \mathrm{the}$ liquids that produced the Hole 735B gabbros, there was no decline in $\mathrm{S}$ contents in residual liquids, although increases in $\mathrm{S}$ contents were retarded after sulfide saturation was achieved.

At Skaergaard, estimated S contents of successive liquids given in Wager and Brown (1967) were impossibly low, because of the degassed and/or altered starting composition (a marginal gabbro) they chose. Even though that choice is now in question (Hoover, 1989), no rocks from Skaergaard or its vicinity are likely to retain pristine abundances of S. Nevertheless, based on analogy to Hole 735B gabbros, the initial S contents of Skaergaard parental liquids were not likely to have been at $\mathrm{S}$ saturation. This is because magmatic sulfides, which occur primarily in very late-stage ferrodiorites, are even more $\mathrm{Cu}$-rich than those of Hole 735B gabbros, being dominated by bornite-cubanite assemblages. Hypothetically, S contents were even further from sulfide saturation than in liquids for Hole 735B (dotted trend for S in Fig. 23), thus providing no mechanism for $\mathrm{Cu}$ depletion until sulfide segregation finally occurred in very iron-rich liquids. At this point, competition for partitioning of iron into very iron-rich pyroxenes and olivine effectively eliminated the availability of $\mathrm{Fe}$ for sulfides, and $\mathrm{Cu}$-rich sulfides formed. Alternatively, small amounts of crustal assimilation that influenced Skaergaard isotopic compositions (Steward and DePaolo, 1990) also influenced transition-metal abundances in very late-stage residual liquids. All this is guesswork, but the strong contrasts between latesegregating sulfide assemblages at Skaergaard and Hole 735B are undeniable.

Finally, Figure 23 allows one to estimate the compositions of immiscibly separated siliceous and iron-rich liquids. The proportion of siliceous liquid is presumed to be either $20 \%$ or $25 \%$, based on balancing $\mathrm{FeO}(\mathrm{mol} \%)$ contents for the ranges of compositions produced experimentally (Fig. 22) by Dixon and Rutherford, 1979). Those experiments suggest that such a range in proportions probably occurs, depending on the precise conditions of immiscibility attained. Individual elemental or oxide abundances in siliceous liquids (all low) combine inferences from the experimental studies, the composition of the trondhjemite at Hole 735B, and the composition of a rhyodacite glass from the East Pacific Rise (J. Natland, unpubl. data). $\mathrm{Mg} \#$ for the siliceous liquid at Hole $735 \mathrm{~B}$ is based on clinopyroxene compositions, as discussed earlier. The eastern Pacific rhyodacite provided the critical information for S (140 ppm; Fig. 15).

The iron-rich liquid left from the segregation of an immiscible siliceous liquid at Hole $735 \mathrm{~B}$ had iron abundances matching those estimated for the most iron-enriched Skaergaard liquids, and $\mathrm{MnO}$ concentrations greatly in excess. Sulfur contents were probably $3000 \mathrm{ppm}$ or more. There is little wonder that ilmenites in Hole $735 \mathrm{~B}$ oxide gabbros are so manganiferous and that oxide concentrations have such high sulfide abundances.

\section{DISCUSSION}

\section{Conditions of Late-Stage Differentiation}

Crystallization of iron-titanium oxides, particularly of titanomagnetite, obviously influences the later liquid line of descent among abyssal-tholeiite liquids; that is, whether extended high-iron differentiation can take place. Two totally contrasting hypotheses concerning oxygen fugacities, which control the crystallization of titanomagnetite, are extant. The first might be termed the lunar approximation, since evolution of extremely iron-enriched liquids on the moon proceeded in an environment virtually without trivalent iron, and in which even chromium existed largely in a divalent state. Lunar rock compositions are such that analyses are conventionally reported without $\mathrm{Fe}_{2} \mathrm{O}_{3}$ (cf. Taylor, 1982). With no possibility of titanomagnetite joining the liquidus, lunar differentiation proceeded unhindered to extreme degrees of iron and titanium enrichment. Indeed, bulk compositions of high-Ti basalts from the lunar maria bear much resemblance to those of oxide-rich Ti-ferrogabbros of Hole 735B. The lunar approximation in abyssal tholeiites might have oxygen fugacities in parental magmas so low that titanomagnetite would necessarily be a very late crystallizing phase, with this leading to strong iron enrichment.

The alternative scheme is to suppose that abyssal tholeiites arrive from the mantle with oxygen fugacities about 2 to $3 \mathrm{log}$ units below those given by the NNO buffer (Christie et al., 1986), but with sufficient $\mathrm{Fe}_{2} \mathrm{O}_{3}$ contents that crystallization of silicate minerals naturally caused an increase in $\mathrm{Fe}^{3+} / \mathrm{Fe}^{2+}$ in residual liquids during closed-system fractionation (Ghiorso and Carmichael, 1985). From petrographic relationships, this must occur to some degree, since oxide minerals clearly join the liquidus in abyssal-tholeiite series only after significant fractionation of olivine and pyroxenes takes place.

The question is, when does titanomagnetite join the liquidus? Existing information, based almost exclusively on extrusive suites, points to stabilization of titanomagnetite at or near the NNO buffer (Fig. 19) for both the suite from the Galapagos Spreading Center (Perfit and Fornari, 1983; Juster et al., 1989) and from Thingmuli volcano, Iceland (Carmichael, 1967). But in both cases, this is conceded to be a result of early crystallization of titanomagnetite, whereas in ideal closedsystem fractionation, oxygen fugacities drive completely across the NNO buffer (Fig. 19) before titanomagnetite crystallizes.

Juster et al. (1989) actually postulated that abyssal tholeiites approach the lunar condition, but proposed that oxygen fugacities became enhanced in the suite from the Galapagos Rift. That is, without an increase in oxygen fugacities, their experimental results indicate that NNO might not have been achieved to allow titanomagnetite to crystallize, at least as early as indicated in the rocks. However, some external factor, which Juster et al. (1989) take to be interaction with crustal rocks, enhanced the oxidation state of this lava suite and permitted early crystallization of titanomagnetite. This drove liquid compositions to high $\mathrm{SiO}_{2}$ abundances and (in contrast to the gabbro suite of Hole 735B) away from any potential for separation of immiscible silicate liquids.

Ghiorso and Carmichael (1985) viewed crustal buffering of oxygen fugacities in exactly the opposite sense. That is, they 


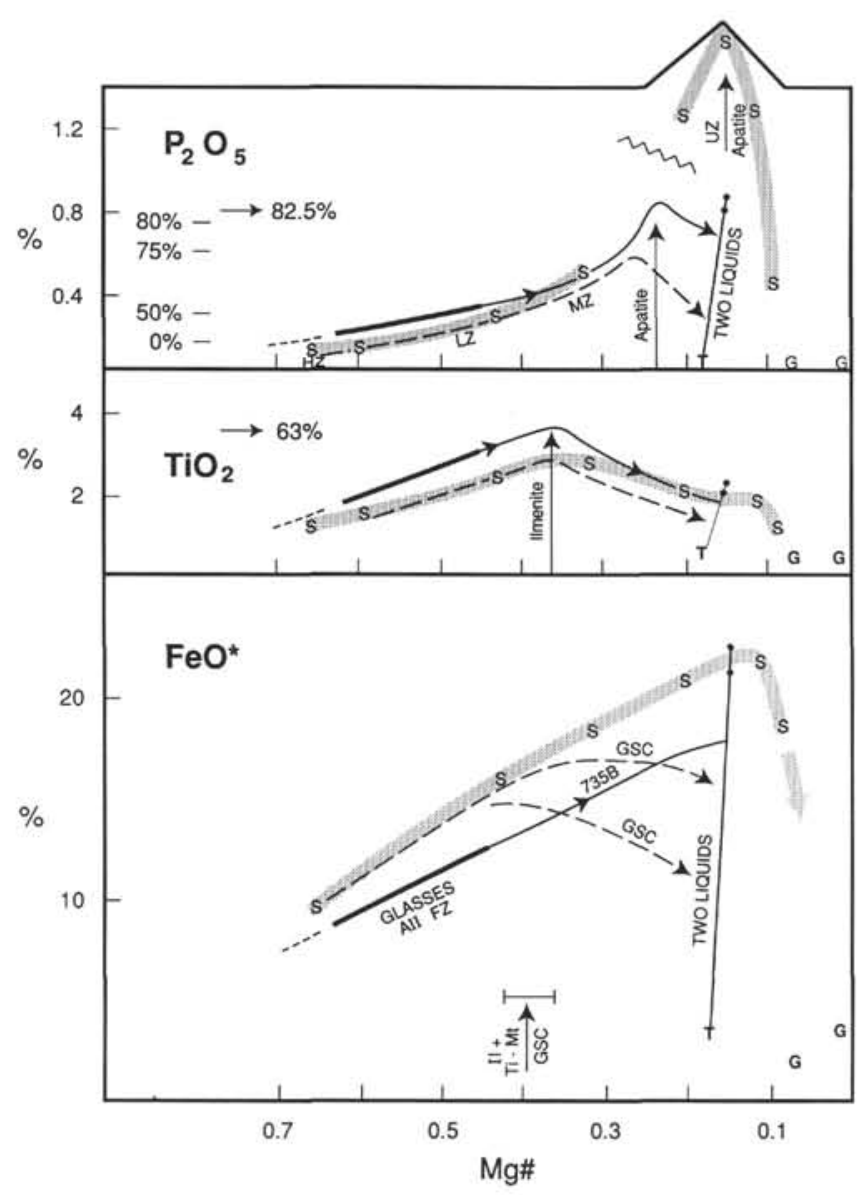

Figure 23. Estimated contents of $\mathrm{P}_{2} \mathrm{O}_{5}, \mathrm{TiO}_{2}, \mathrm{FeO}^{*}, \mathrm{MnO}$, and $\mathrm{S}$ vs. $\mathrm{Mg}$ \# for liquids responsible for Hole $735 \mathrm{~B}$ (solid lines) compared to calculated Skaergaard liquids (Ss; Wager and Brown, 1967) and glasses from the Galapagos Spreading Center (Perfit and Fornari, 1983; Perfit et al, 1983). G = Tinden granophyre at Skaergaard. The bold portions of the trends for Hole 735B are derived from glass compositions; the dashed extensions to $\mathrm{Mg} \#=0.7$ suggest compositions of ultimate parental magmas. Details of the diagram, including estimates of percentages of crystallization, the points where ilmenite and apatite join the liquidus, and the eventual separation of immiscible liquids, are discussed in the text.

considered crustal interaction to be the mechanism of restraining enhancement of oxygen fugacities to levels no higher than NNO by causing titanomagnetite to stay on the liquidus, consuming excess $\mathrm{Fe}^{3+}$ provided by crystallization of ferromagnesian silicates. Other buffering mechanisms, such as sulfate reduction (Carmichael and Ghiorso, 1986), may influence the course of fractionation.

However, Skaergaard may be a case where oxygen fugacities never attained NNO and, indeed, where continued highiron fractionation was actually attended by reduction in oxygen fugacities (from near FMQ toward wüstite-magnetite, or WM; Morse et al., 1980). A scheme invoking even more reducing conditions, wherein Skaergaard liquids were controlled by a carbon buffer between the iron-wüstite and wüstite-magnetite buffers, was proposed by Sato and Valenza (1980). This is perhaps the closest suggested terrestrial match to the lunar approximation.

On balance, to the extent that gabbros from Hole 735B are similar to those from Skaergaard and that crustal interaction

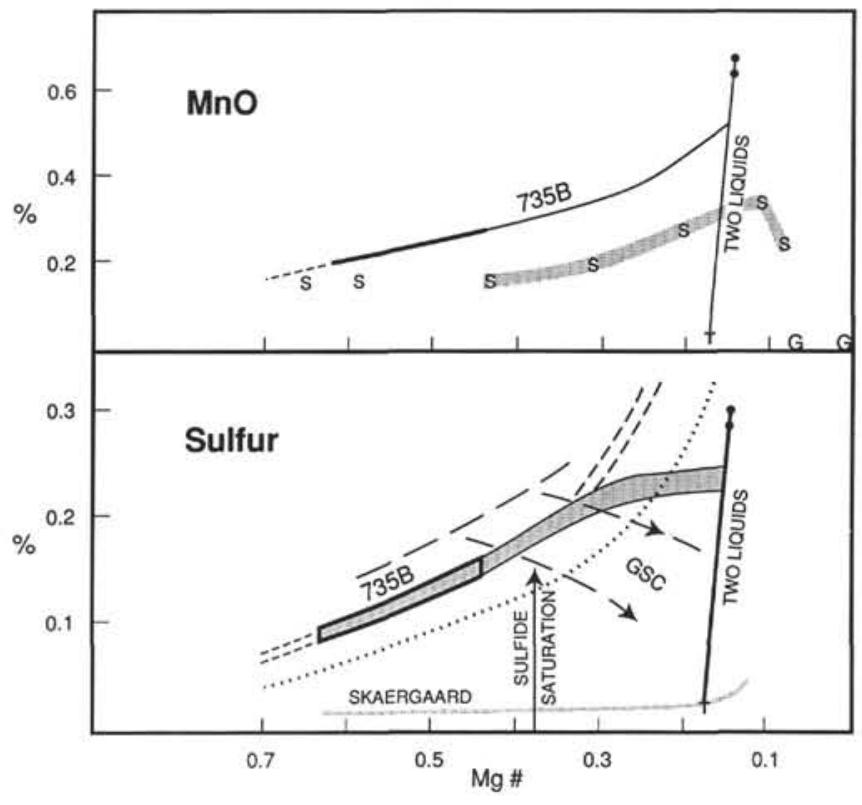

Figure 23 (continued).

seems required to have titanomagnetite crystallize early, an approach to the lunar approximation seems more appropriate for Hole 735B gabbros than closed-system fractionation across the NNO buffer. Firmly establishing this for the oxide gabbros of Hole 735B may be extremely difficult, inasmuch as conditions of recrystallization of iron-titanium oxides were at or below FMQ (Fig. 19), and the proportions of ilmenite to magnetite may have been modified during high-temperature interactions with hydrous fluids (producing brown amphiboles). If anything, recrystallization may have caused a move away from NNO toward FMQ as temperatures decreased (Fig. 19).

The question remains, what enhanced oxygen fugacities in the suite from the Galapagos Spreading Center? If it was crustal interaction, then melts must have exchanged components for oxygen in hydrated crust previously altered by oxygenating seawater. The contrast to Hole $735 \mathrm{~B}$ may have been that fractionation took place in extremely shallow crust, where iron oxyhydroxides, clay minerals rich in ferric iron, and oxygenated seawater were abundant. The gabbros of Hole $735 \mathrm{~B}$, however, are mid-crustal rocks that were altered within gabbroic layer 3, about $2 \mathrm{~km}$ below the seafloor (Vanko and Stakes, this volume). This places their crystallization at about this depth as well. Here, thermal gradients and porosity structure inhibited access of oxygenated seawater to the crystallizing magma chamber. Extended high-iron differentiation resulted, in the manner of Skaergaard.

\section{Why Are There No Melanogranophyres?}

Comparisons to Skaergaard point to an important problem in tholeiite petrogenesis. Skaergaard is taken to represent a complete differentiation sequence resulting from high-iron differentiation. As such, Upper Zone melanogranophyres are considered to bridge the gap between the most iron-enriched ferrogabbros and certain felsic granophyres at Skaergaard. Now, a general characteristic of the ocean crust has emerged. Nowhere at several dozen locations in the ocean basins where gabbros have been sampled have melanogranophyres also been obtained. Moreover, at Hole 735B, there is a disconti- 


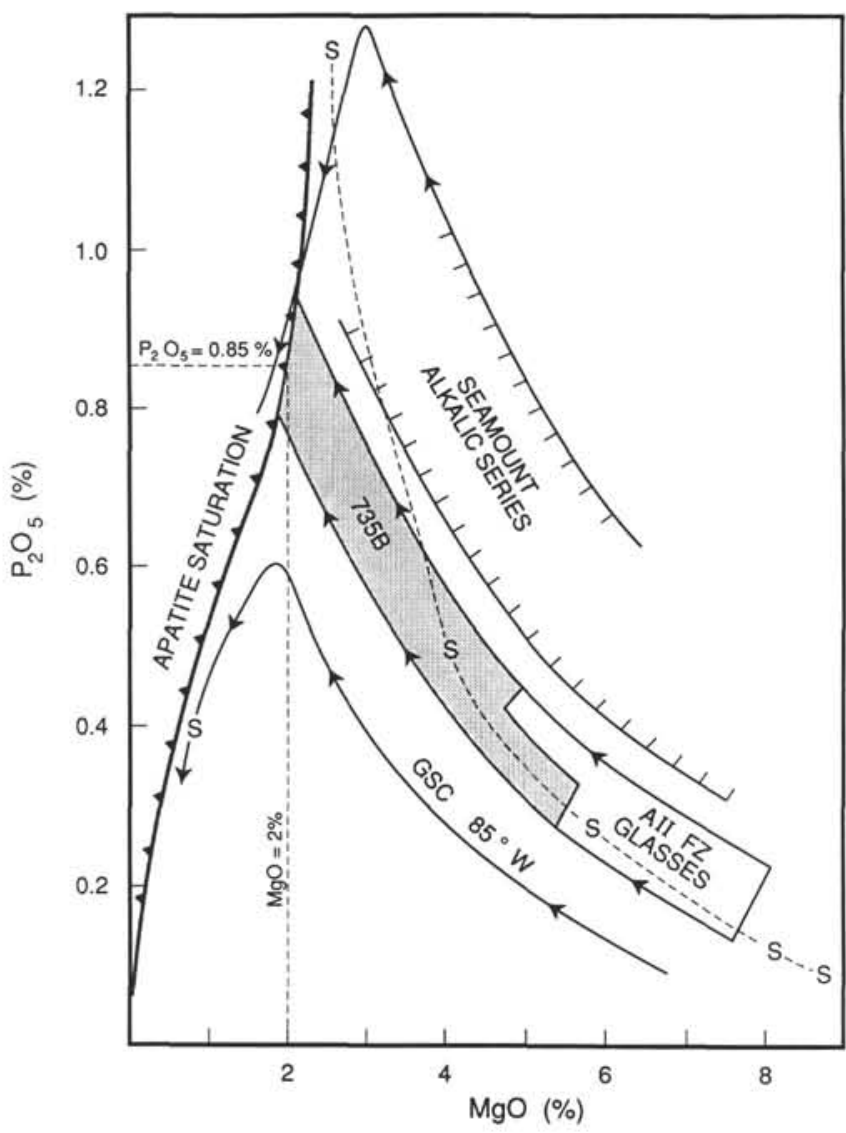

Figure 24. $\mathrm{P}_{2} \mathrm{O}_{5}$ vs. $\mathrm{MgO}$ variation in glasses from Atlantis II Fracture Zone (generalized) and the extrapolated continuation at Hole 735B to apatite saturation, used in constructing portions of Figure 23. The Hole 735B trend has been inferred as concentric to, and to lie between, trends for the Galapagos Spreading Center (Perfit et al., 1983) and alkalic series glasses from a seamount province off northern Mexico (Gee et al., in press; and J. Natland, unpubl. data). Estimated Skaergaard liquids (Wager and Brown, 1967) are given by Ss linked by a dashed line. The apatite saturation boundary is based on experimental determinations of Harrison and Watson (1984).

nuity in compositions between the most oxide-rich gabbros and trondhjemite that crosscuts those same gabbros. The trondhjemite is compositionally similar to the Skaergaard Tinden granophyre (Fig. 5B), which incidentally has also been attributed to immiscible segregation (McBirney and Nakamura, 1974). But the more abundant, less albitic, evolved melanogranophyres of the Skaergaard are unknown in the ocean crust. Such rocks are pyroxenic, rather than oxide-rich, and the two pyroxenes they contain (as well as olivine) are extremely iron rich (Wager and Brown, 1967).

Several factors may have inhibited evolution of melanogranophyres at Hole 735B in contrast to Skaergaard: (1) no continental crust was there to assimilate (cf. Steward and DePaolo, 1990), either to enhance oxygen fugacities or to add silica to the system; (2) the rocks are a composite of many small intrusive bodies that, for the most part, crystallized separately, rather than as one much larger body of rock; (3) the rocks experienced late differentiation concurrently with deformation, which acted to squeeze residual melts from the rocks; and (4) the gabbros were linked in an open system throughout much of their crystallization history to flux of basalt to the seafloor. The situation was dynamic, rather than static. Thus, at the final stages of differentiation, evolved liquids were continuously reintegrated with, or moved around in, the partially crystalline mass of rock. The deformation process enabled squeezed liquids to blend with intrusive basalt magmas. No substantial interval of melanogranophyres survived; rather, it was dispersed to many places, but primarily into the basaltic layer of the ocean crust.

Still, the influence of assimilated continental crust at Skaergaard may well have tipped the balance toward formation of abundant siliceous melanogranophyres and granophyres that would not otherwise have occurred.

\section{Magmatic Differentiation in Deforming Crust}

At Hole $735 \mathrm{~B}$, the evidence is clear that magmatic differentiation occurred during and after episodes of high-temperature ductile deformation of the rocks. However, whether differentiation was actually promoted by deformation remains an open question. Evidence has been presented that deformation reduced residual melt porosities and contributed excluded elements to through-going basalt magmas. This certainly affected the course of differentiation. To the extent that some magmas were forced to migrate into cooler rock, deformation did indeed promote differentiation.

A more subtle question is whether the bimodal compositional range of the gabbro suite may have resulted from removal of evolved magmatic liquids in certain portions of the magma body to others. This view, argued by Dick et al. (this volume), simply supposes that removal of evolved liquids effectively will terminate intercumulus differentiation at some spots (leaving them with mafic compositions) and continue such differentiation elsewhere (providing low-temperature gabbro compositions against a background of higher-temperature mafic gabbros).

Given the low residual porosities of almost all the gabbros, this is a fair description of what must have occurred. But it is important to bear in mind that several different parental lineages were involved and that intrusion by new magma took place several times. The package of molten material was added to, not simply (or only) rearranged during the process of deformation. The actual proportions of rock types recovered from Hole 735B and indicating bimodality is circumstantial; it is not replicated by gabbroic suites obtained by dredging elsewhere in the Indian Ocean (Fig. 10).

An alternative supposes that a more-or-less uniform body of olivine gabbro, perhaps with its residual liquid already squeezed out by deformation related to listric normal faulting in the rift valley, was injected some time after its formation by one or more substantial intrusions of ferrobasalt, probably along a region of neutral buoyancy in the crust for magmas of that density (Ryan, 1987). These continued to fractionate while ductile deformation was going on, which partially redistributed the molten material along fissures and in porosity structure developing in the original crystalline mass. The host rock, although deprived of its residual melt fraction, was still above its original solidus temperature.

But after a period of crystallization of the intruding liquids, they stopped behaving like liquids in an environment of shear and began to take up strain on a developing crystalline framework. Too, their residual liquids were squeezed from the rocks, probably being completely removed rheologically speaking, at a uniform temperature wherever they happened to be up and down the short section of rock we cored. Deformation arrested in situ differentiation by driving off residual melts completely. That this happened twice at different temperatures, following intrusion of the liquids that produced the olivine gabbros and disseminated oxide gabbros, is the fundamental explanation for the bimodal distribution of 
bulk compositions in the core. But bimodal compositions could not have developed at all without the two intrusive events.

Then, even more-evolved ferrobasaltic melts of slightly different parentage intruded the section. These melts were emplaced at one principal level in the section (lithologic Unit IV). They differentiated to the extent that immiscible separation of siliceous, trondhjemitic, and very iron-rich liquids occurred. Based on experimental results, this was at or near $1000^{\circ} \mathrm{C}$ (Dixon and Rutherford, 1979). Evolved liquids still remaining within lithologic Unit IV became irregularly, but closely, distributed in pockets within a rheologically diverse matrix of solid and partially molten rock. In such a regime, very dense iron-rich liquids did their best to sink and buoyant silicic liquids to rise. There were local, sometimes fairly chaotic, disruptions of the matrix rocks as this redistribution took place. Dense, iron-rich liquids concentrated at porositylimiting horizons. Substantial fissure systems probably developed in the underlying rocks, allowing the dense liquids to penetrate through them (to lithologic Unit VI). But in the end, ductile deformation persisted to the point where residual interstitial melts were squeezed out even from these lastintruded, highly evolved oxide-rich gabbroic rocks.

The overall deformation process thus influenced the compositions of partially molten rocks that crystallized between about $1160^{\circ}$ and $1000^{\circ} \mathrm{C}$. This carried through to the subsolidus recrystallization of pyroxenes down to about $800^{\circ} \mathrm{C}$. Ductile deformation was thus a dominant factor in both the igneous petrogenesis and the high-grade metamorphism of the gabbros.

The pervasive deformation may have had one other important consequence. It apparently allowed seawater-derived fluids access to all parts of the cooling body of rock. This accelerated cooling rates, allowing recrystallization of pyroxenes and especially magmatic oxides to occur, to temperatures eventually at or near closure in the presence of hydrous fluids and amphiboles, near $600^{\circ} \mathrm{C}$. More massive bodies of cooling rock, with less deformation, were neither so efficiently nor uniformly cooled (i.e., Skaergaard; Fig. 18).

\section{CONCLUSIONS}

The gabbroic suite of Hole 735B, the first significant recovery by drilling of rock assemblages from oceanic layer 3 , sheds new light on the advanced differentiation of abyssaltholeiite magma. An extended Skaergaard-type of high-iron differentiation led to crystallization of ferrogabbros, some of which contain remarkable abundances of iron-titanium oxides. Mineral compositions combined with information about the compositions of basaltic glasses dredged from the vicinity define a general liquid line of descent. A special aspect of this is that initial sulfide undersaturation in the melt led to deferred segregation of immiscible sulfide globules. Consequently, these are chalcopyrite-rich and are highly abundant in oxide ferrogabbros.

The liquids reached compositions comparable to those from which immiscible siliceous and very iron-rich liquids separated in experimental studies. The siliceous component is seen as trondhjemitic dikelets at Hole $735 \mathrm{~B}$, and the more voluminous iron-rich component probably was responsible for formation of oxide concentrates. These developed partly in response to high-temperature ductile deformation of the rocks, which occurred concurrently with all stages of differentiation of the gabbros. The deformation continually reduced the percentage of residual melts to virtually nothing by squeezing them from the rocks. This enhanced abundances of excluded elements in through-going basaltic intrusives, as evidenced by compositions of basalt glasses dredged from the vicinity.
Explicit comparisons to the similar Skaergaard Intrusion and a lava suite from the Galapagos Spreading Center point to the subtle but important role of oxygen fugacities for determining when titanomagnetite joins the liquidus in tholeiiticseries melts. This greatly influences whether differentiation will trend toward silica-enrichment (as at the Galapagos Rift), or continue toward higher iron-enrichment and eventual liquid immiscibility, as in the gabbros of Hole 735B.

Continued subsolidus deformation and recrystallization of the gabbros of Hole 735b provided many of them with a strong porphyroclastic to gneissic texture. Access of hydrous fluids permitted efficient cooling of the rock mass and promoted the extensive recrystallization observed in almost every rock.

\section{ACKNOWLEDGMENTS}

We thank shipboard colleagues Mathilde Cannat, Rejean Hébert, Pamela Kempton, Kazuhito Ozawa, and Debra Stakes for their contributions to rock and thin-section descriptions during Leg 118, and Rolf Emmermann and Jan Hertogen, together with technician Wendy Autio, for their splendid set of shipboard X-ray fluorescence analyses. Janet Pariso provided a very useful oxide/sulfide crib sheet for petrographic identifications. Marine Technician Joe Powers skillfully made an unbelievable number of polished thin sectionsmore than 300 -within a three-week period during Leg 118 , some of which were used in this study. At Scripps Institution, Roy Fujita provided his usual able assistance with the electron microprobe. The manuscript benefitted from comments by Jamie Allan and two anonymous reviewers, plus correspondence with A. R. McBirney and C. K. Brooks. This work was sponsored by the U.S. Science Support Program of the U.S. Science Advisory Committee for the Ocean Drilling Program.

\section{REFERENCES}

Anderson, A. T., and Greenland, L. P., 1970. Phosphorus fractionation diagram as a quantitative indicator of crystallization differentiation of basaltic liquids. Geochim. Cosmochim. Acta, 33:493505 .

Autio, L., and Rhodes, J. M., 1983. Costa Rica Rift Zone basalts: Geochemical and experimental data from a possible example of multistage mixing. In Cann, J. R., Langseth, M., Honnorez, J., Von Herzen, R. P., White, S. M., et al., Init. Repts. DSDP, 69: Washington (U.S. Gov't. Printing Office), 729-745.

Barton, P. B., Jr., and Skinner, B. J., 1979. Sulfide mineral stabilities. In Barnes, H. L. (Ed.), Geochemistry of Hydrothermal Ore Deposits, 2nd Ed.: New York (Wiley), 278- 403.

Bloomer, S. H., Natland, J. H., and Fisher, R. L., 1989. Mineral relationships in gabbroic rocks from fracture zones of Indian Ocean Ridges: Evidence for extensive fractionation, parental diversity, and boundary-layer recrystallization. In Saunders, A. D., and Norry, M. J. (Eds.), Magmatism in the Ocean Basins. Geol. Soc. London Spec. Publ., 42:107-124.

Bottinga, Y., and Weill, D. F., 1970. Densities of liquid silicate systems calculated from partial molar volumes of oxide components. Am. J. Sci., 269:169-182.

Bougault, H., Cambon, P., and Toulhoat, H., 1977. X-ray spectrometric analysis of trace elements in rocks: correction for instrumental interferences. X-ray Spectrometry, 6:66-72.

Bougault, H., Cande, S., et al., 1983. Init. Repts. DSDP, 82: Washington (U.S. Govt. Printing Office).

Bowen, N. L., and Schairer, J. F., 1935. The system MgO-FeO-SiO 2 . Am. J. Sci., 29:151- 217.

Brooks, C. K., 1968. On the interpretation of trends in element ratios in differentiated igneous rocks, with particular reference to strontium and calcium. Chem. Geol., 3:15-20.

Brooks, C. K ., and Nielsen, T.F.D., 1990. A discussion of Hunter and Sparks (Contrib. Mineral. Petrol. 95:452-461). Contrib. Mineral. Petrol., 104:244-247.

Carmichael, I.S.E., 1964. Petrology of Thingmuli, a Tertiary volcano in eastern Iceland. J. Petrol., 5:321-335. 
1967. The mineralogy of Thingmuli, a Tertiary volcano in eastern Iceland. Am. Mineral., 52:1815-1841.

Carmichael, I.S.E., and Ghiorso, M. S., 1986. Oxidation-reduction relations in basic magma: a case for homogeneous equilibria. Earth Planet. Sci. Lett., 79:397-411.

Chalokwu, C. L., and Grant, N. K., 1990. Petrology of the Partridge River Intrusion, Duluth Complex, Minnesota: 1. Relationships between mineral compositions, density, and trapped liquid abundance. J. Petrol., 31:265-293.

Christie, D. M., Carmichael, I.S.E., and Langmuir, C. H., 1986. Oxidation states of mid-ocean-ridge basalt glasses. Earth Planet. Sci. Lett., 79:397-411.

Christie, D. M., and Sinton, J. M, 1981. Evolution of abyssal lavas along propagating segments of the Galapagos Spreading Center. Earth Planet. Sci. Lett., 56:321-335.

Czamanske, G. K., and Moore, J. G., 1977. Composition and phase chemistry of sulfide globules in basalt from the Mid-Atlantic Ridge rift valley near $37^{\circ} \mathrm{N}$ lat. Geol. Soc. Am. Bull., 88:587-599.

Dick, H.J.B., 1989. Abyssal peridotites, very slow spreading ridges, and ocean ridge magmatism. In Saunders, A. D., and Norry, M. J. (Eds.), Magmatism in the Ocean Basins, Geol. Soc. London Spec. Publ., 42:71-106.

Dick, H.J.B., Fisher, R. L., and Bryan, W. B., 1984. Mineralogic variability of the uppermost mantle along mid-ocean ridges. Earth Planet. Sci. Lett., 69:88-106.

Dixon, S., and Rutherford, M. J., 1979. Plagiogranites and late-stage immiscible liquids in ophiolites and mid-ocean ridge suites: An experimental study. Earth Planet. Sci. Lett., 45:45-60.

Duke, J. M., 1976. Distribution of Period Four transition elements among olivine, calcic clinopyroxene, and mafic silicate liquid: experimental results. J. Petrol., 17: 499-521.

Engel, C. G., and Fisher, R. L., 1975. Granitic to ultramafic rock complexes of the Indian Ocean Ridge system, western Indian Ocean. Geol. Soc. Am. Bull., 86:1553-1578.

Fisher, R. L., Dick, H.J.B., Natland, J. H., and Meyer, P. S., 1986. Mafic/ultramafic suites of the slowly spreading Southwest Indian Ridge: Protea exploration of the Antarctic Plate Boundary, $24^{\circ}$. $47^{\circ}$ E. Ofioliti, 11: 147-178.

Francis, R. D., 1980. On the fractionation of sulfur, copper, and related transition elements in silicate liquids [Ph.D. thesis]. Univ. of California, San Diego (unpubl.).

Gee, J., Staudigel, H., and Natland, J. H., in press. Geology and petrology of Jasper Seamount. J. Geophys. Res.

Ghiorso, M. S., and Carmichael, I.S.E., 1985. Chemical mass transfer in magmatic processes II. Applications in equilibrium crystallization, fractionation, and assimilation. Contrib. Mineral. Petrol. 90:12I-14I.

Harrison, T. M., and Watson, E. B., 1984. The behavior of apatite during crustal anatexis: Equilibrium and kinetic considerations. Geochem. Cosmochim. Acta, 48:1467-1477.

Hess, H. H., 1939. Extreme fractional crystallization of a basaltic magma: the Stillwater igneous complex. Trans. Am. Geophys. Union, 3:431-432.

Hoover, J. D., 1989. The chilled marginal gabbro and other contact rocks of the Skaergaard Intrusion. J. Petrol., 30:441-476.

Hunter, R. H., and Sparks, R.S.J., 1987. The differentiation of the Skaergaard Intrusion. Contrib. Mineral. Petrol., 95:451-461. 1990a. The differentiation of the Skaergaard Intrusion: Reply to A.R. McBirney and H.R. Naslund. Contrib. Mineral. Petrol., 104 248-251.00 $104: 251-253$

1990b. Reply to S. A. Morse. Contrib. Mineral. Petrol. 1990c. Reply to C. K. Brooks and T.F.D. Nielsen. Contrib. Mineral. Petrol., 104:253-254.

Irvine, T. N., 1979. Rocks whose composition is determined by crystal accumulation and sorting. In Yoder, H. S. (Ed.), The Evolution of the Igneous Rocks-Fiftieth Anniversary Perspectives: Princeton, N.J. (Princeton Univ. Press), 245-306.

Jarosewicz, E., Nelen, J., and Norberg, J., 1979. Electron microprobe reference samples for mineral analyses. In Fudali, R. F. (Ed). Smithsonian Contrib. Earth Sci., 94:9251-9247.

Johnson, K.T.M., Dick, H.J.B., and Shimizu, N., 1989. Melting in the oceanic upper mantle: an ion microprobe study of diopsides in abyssal peridotites. J. Geophys. Res., 95:2661-2678.
Juster, T. C., Grove, T. L., and Perfit, M. R., 1989. Experimental constraints on the generation of FeTi basalts, andesites, and rhyodacites at the Galapagos Spreading Center, $85^{\circ} \mathrm{W}$ and $95^{\circ} \mathrm{W} . J$. Geophys. Res., 94:9251-9247.

Klein, E. M., and Langmuir, C. H., 1987. Ocean ridge basalt chemistry, axial depth, crustal thickness, and temperature variations in the mantle. J. Geophys. Res., 92:8089-8115.

Langmuir, C. H., 1989. Geochemical consequences of in-situ crystallization. Nature, 340:199-205.

Langmuir, C. H., and Bender, J. F., 1984. The geochemistry of oceanic basalts in the vicinity of transform faults: observations and implications. Earth Planet. Sci. Lett., 69:107-127.

Lindsley, D. H., 1983. Pyroxene thermometry. Am. Mineral., $68: 477-491$.

Mahoney, J. J., Natland, J. H., White, W. M., Poreda, R., Bloomer, S. H., Fisher, R. L., and Baxter, A. N., 1989. Isotopic and geochemical provinces of the western Indian Ocean spreading centers. J. Geophys. Res., 94:4033-4052.

Mathez, E., 1976. Sulfur solubility and magmatic sulfides in submarine basalt glass. J. Geophys. Res., 81:4269-4276.

1980. Sulfide relations in Hole 418A flows and sulfur contents of glasses. In Donnelly, T., Francheteau, J., Bryan, W. B., Robinson, P., Flower, M., Salisbury, M., et al., Init. Repts. DSDP, 51, 52, 53, Pt. 2: Washington (U.S. Govt. Printing Office), 1069- 1085 .

Mattey, D. P., and Muir, I. D., 1983. Geochemistry and mineralogy of basalts from the Galapagos Spreading Center, Deep Sea Drilling Project Leg 54. In Rosendahl, B. R., Hekinian, R., et al., Init. Repts. DSDP, 54: Washington (U.S. Govt. Printing Office), 755- 771.

McBirney, A., 1975. Differentiation of the Skaergaard Intruison. Nature, 253:691-694.

1989. The Skaergaard Layered Series: I. Structure and average composition. J. Petrol., 30:363-397.

McBirney, A., and Nakamura, Y., 1974. Immiscibility in late-stage magmas of the Skaergaard Intrusion. Carnegie Inst. Washington Yrbk., 73:348-352.

McBirney, A., and Naslund, H. R., 1990. The differentiation of the Skaergaard Intrusion: a discussion of Hunter and Sparks (Contrib. Mineral. Petrol., 95:451-461). Contrib. Mineral. Petrol., 104:235243.

McKenzie, D., 1984. The generation and compaction of partially molten rock. J. Petrol., 25:713-765.

Melson, W. G., Aumento, F., et al., 1977. Init. Repts. DSDP, 37: Washington (U.S. Govt. Printing Office).

Meyer, P. S., Dick, H.J.B., and Thompson, G., 1989. Cumulate gabbros from the Southwest Indian Ocean, $54^{\circ} \mathrm{S}, 7^{\circ} 16^{\prime} \mathrm{E}$ : Implications for magmatic processes at a slow spreading ridge. Contrib. Mineral. Petrol.

Meyer, P. S., and Shibata, T., 1989. Complex zoning in plagioclase feldspars from ODP Site 648. In Detrick, R., Honnorez, J., Bryan, W. B., Juteau, T., et al., Proc. ODP, Sci. Results, 106/109: College Station, TX (Ocean Drilling Program), 123-142.

Miller, J. N., and Weiblen, P. W., 1990. Anorthositic rocks of the Duluth Complex: Examples of rocks formed from plagioclase crystal mush. J. Petrol., 31:295-339.

Morse, S. A., 1979a. Kiglapait geochemistry I: Systematics, sampling, and density. J. Petrol., 20:555-590.

1979b. Kiglapait geochemistry II: Petrography. J. Petrol., $32: 591-624$

1982. Kiglapait geochemistry V: Strontium. Geochim. Cosmochim. Acta, 46:223-234.

1990. A discussion of Hunter and Sparks (Contrib. Mineral Petrol., 95:451-461). Contrib. Mineral. Petrol., 104:240-244.

Morse, S. A., Lindsley, D. H., and Williams, R. J., 1980. Concerning intensive parameters in the Skaergaard Intrusion. Am. J. Sci., 280A: $159-170$.

Naslund, H. R., 1983. The effect of oxygen fugacity on liquid immiscibility in iron-bearing silicate melts. Am. J. Sci., 283:1034-1059.

1984. Petrology of the Upper Border Series of the Skaergaard Intrusion. J. Petrol., 25:185-212.

Natland, J. H., 1980. Effect of axial magma chambers beneath spreading centers on the compositions of basaltic rocks. In Rosendahl, B. R., Hekinian, R., et al., Init. Repts. DSDP, 54: Washington (U.S. Govt. Printing Office), 833-850. 
1989. Partial melting of a lithologically heterogeneous mantle: Inferences from crystallization histories of magnesian abyssal tholeiites from the Siqueiros Fracture Zone. In Saunders, A. D., and Norry, M. J. (Eds.), Magmatism in the Ocean Basins. Geol. Soc. London Spec. Publ., 42:41-70.

Adamson, A. C. Laverne, C., Melson, W. G., and O'Hearn, T., 1983. A compositionally nearly steady-state magma chamber at the Costa Rica Rift: evidence from basalt glass and mineral data, Deep Sea Drilling Project Sites 501, 504, and 505. In Cann, J. R., Langseth, M., Honnorez, J., Von Herzen, R. P., White, S. M., et al., Init. Repts. DSDP, 69: Washington (U.S. Govt. Printing Office), 811-859.

and Melson, W. G., 1980. Compositions of basaltic glasses from the East Pacific Rise and Siqueiros Fracture Zone, near $9^{\circ} \mathrm{N}$. In Rosendahl, B. R., Hekinian, R., et al., Init. Repts. DSDP, 54: Washington (U.S. Govt. Printing Office), 705-723.

Nisbet, E. G., and Fowler, C.M.R., 1978. The Mid-Atlantic Ridge at $37^{\circ} \mathrm{N}$ and $45^{\circ} \mathrm{N}$ : some geophysical and petrological constraints. Geophys. J. Royal Astron. Soc., 45:631-660.

Nwe, Y. Y., 1976. Electron probe studies of the earlier pyroxenes and olivines from the Skaergaard Intrusion, East Greenland. Contrib. Mineral. Petrol., 55:105-126.

O'Hara, M. J., and Mathews, R. E., 1981. Geochemical evolution in an advancing, periodically replenished, periodically tapped, continuously fractionating magma chamber. J. Geol. Soc. (London), 138:237-277.

Osborn, E. F., 1959. Role of oxygen pressure in the crystallization and differentiaiton of basaltic magma. Am. J. Sci., 257:609-647.

, 1979. The reaction principle. In Yoder, H. S., Jr. (Ed.), The Evolution of the Igneous Rocks-Fiftieth Anniversary Perspectives: Princeton, NJ (Princeton Univ. Press), 133-169.

Perfit, M. J., and Fornari, D., 1983. Geochemical studies of abyssal lavas recovered by DSRV Alvin from Eastern Galapagos Rift, Inca Transform, and Ecuador Rift, 2. Phase chemistry and crystallization history. J. Geophys. Res., 88:10,530-10,550.

Perfit, M. J., Fornari, D., Malahoff, A., and Embley, R. W., 1983. Geochemical studies of abyssal lavas recovered by DSRV Alvin from eastern Galapagos Rift, Inca Transform, and Ecuador Rift, 3. Trace-element abundances and petrogenesis. J. Gephys. Res., $88: 10,551-10,572$.

Philpotts, J. A., and Schnetzler, C. C., 1970. Phenocrysts for K, Rb, $\mathrm{Sr}$, and $\mathrm{Ba}$, with applications to anorthosite and basalt genesis. Geochim. Cosmochim. Acta, 304:307-332.

Presnall, D., Dixon, J. R., O'Donnell, T. H., and Dixon, S. A., 1979. Generation of mid-ocean ridge basalts. J. Petrol., 20:3-35.

Robinson, P. T., Von Herzen, R. P., et al., 1989. Proc. ODP, Init. Repts., 118: College Station, TX (Ocean Drilling Program).

Roedder, E., 1979. Silicate liquid immiscibility in magmas. In Yoder, H. S., Jr. (Ed.), The Evolution of the Igneous Rocks-Fiftieth Anniversary Perspectives: Princeton, NJ (Princeton Univ. Press), $15-57$.

Roeder, P. L., 1974. Activity of iron and iron solubility in basaltic liquids. Earth Planet. Sci. Lett., 23:397-410.

Roeder, P. L., and Emslie, R. F., 1970. Olivine-liquid equilibria. Contrib. Mineral. Petrol., 29:275-289.

Ryan, M., 1987. Neutral buoyancy and the mechanical evolution of magmatic systems. in Mysen, B. O. (Ed.), Magmatic Processes: Physicochemical Principles. Geochem. Soc. Spec. Publ., 1:259-287.

Sato, M., and Valenza, M., 1980. Oxygen fugacities of the Layered Series of the Skaergaard Intrusion, East Greenland. Am. J. Sci., 280A:134-158.

Sigurdsson, H., and Sparks, R.S.J., 1981. Petrology of acid and mixed magma ejecta from the 1875 eruption of Askja, Iceland. J. Petrol., 22:43-84.

Spencer, K., and Lindsley, D. H., 1981. A solution model for coexisting iron-titanium oxides. Am. Mineral., 66:1189-1201.

Steward, B. W., and DePaolo, D. J., 1990. Isotopic studies of processes in mafic magma chambers: II. The Skaergaard Intrusion, East Greenland. Contrib. Mineral. Petrol., 104:125-141.

Stormer, J. C., Jr., 1983. The effects of recalculation on estimates of temperature and oxygen fugacity from analyses of multi-component iron-titanium oxides. Am. Mineral., 68:568-594.

Sun, C.-O., Williams, R. J., and Sun, S.-S., 1974. Distribution coefficients of $\mathrm{Eu}$ and $\mathrm{Sr}$ for plagioclase-liquid and clinopyroxene- liquid equilibria in oceanic ridge basalt: An experimental study. Geochim. Cosmochim. Acta, 38:1415-1433.

Taylor, S. R., 1982. Planetary Science: A Lunar Perspective: Houston (Lunar Planet. Inst.).

Vincent, E. A., and Phillips, R., 1954. Iron-titanium oxide minerals in layered gabbros of the Skaergaard Intrusion, East Greenland, Part 1. Chemistry and ore-microscopy. Geochim. Cosmochim. Acta, 6:1-26.

Wager, L. R., 1960. The major-element variation of the layered series of the Skaergaard Intrusion and a re-estimation of the average composition of the hidden layered series and of the successive residual magmas. J. Petrol., 1:364-398.

Wager, L. R., and Brown, G. M., 1967. Layered Igneous Rocks, San Francisco (W. H. Freeman).

Whitehead, J. A., Dick, H.J.B., and Schouten, H., 1984. A mechanism for magmatic accretion under spreading centers. Nature, 312:146-148.

Date of initial receipt: 18 December 1989

Date of acceptance: 20 September 1990

Ms 118B-163

\section{APPENDIX A}

Procedures for Estimating Residual Melt Porosity and Parental Strontium

Residual Melt Porosity

1. Relate bulk $\mathrm{Mg} \# \mathrm{~s}$ of gabbros to parental liquid compositions.

Let $\mathrm{Mg}_{\mathrm{L}}=\mathrm{Mg} \#$ of liquid and $\mathrm{Mg}_{\mathrm{R}}=\mathrm{Mg} \#$ of rock, where

$$
\mathrm{Mg} \#=\mathrm{Mg} /\left(\mathrm{Mg}+\mathrm{Fe}^{2+}\right),
$$

with $\mathrm{Fe}^{2+} /\left(\mathrm{Fe}^{2+}+\mathrm{Fe}^{3+}\right)=0.86$ (Presnall et al., 1979).

Also let $X_{\mathrm{R}}=X$ in gabbro, $X_{\mathrm{L}}=X$ in liquid and $X_{\mathrm{cpx}}=X$ in clinopyroxene, where $X=\mathrm{Zr}$, $\mathrm{TiO}_{2}$, or $\mathrm{P}_{2} \mathrm{O}_{5}$.

Partition coefficients are $D=C_{\mathrm{cpx}} / C_{\text {liquid }}$, where $C=$ concentration in a phase and

$$
D(\mathrm{Zr})=0.14 ; D\left(\mathrm{TiO}_{2}\right)=0.44 ; D\left(\mathrm{P}_{2} \mathrm{O}_{5}\right)=0 .
$$

Value for $\mathrm{TiO}_{2}$ from Johnson et al. (1989), for $\mathrm{Zr}$ from Equation A1 (see discussion below), and assumed zero for $\mathrm{P}_{2} \mathrm{O}_{5}$ (Anderson and Greenland, 1970). $K_{D}$ s are assumed to be effectively zero for plagioclase and olivine.

For olivine gabbros, assume bulk $\mathrm{Mg \#}=\mathrm{Mg} \#(\mathrm{cpx})$. From Duke (1976),

$$
\mathrm{Mg}_{\mathrm{L}}=\left[10^{\left(\operatorname { l o g } \left(11-\mathrm{Mg}_{\mathrm{g}}\right.\right.} \mathrm{R}^{1 / \mathrm{Mg}} \mathrm{R}^{)+0.6477 / 0.755)}+1\right)^{-1}
$$

The intercept value $(0.6477)$ is slightly modified from the value in Duke (1976) to let olivines crystallize before clinopyroxenes in the suite of Galapagos Rift basalts described by Perfit and Fornari (1983).

For troctolites, assume bulk $\mathrm{Mg} \#=\mathrm{Mg}$ (olivine). Again, from Duke (1976),

$$
\mathrm{Mg}_{\mathrm{L}}=\left[10^{\left(\log \left(11-\mathrm{Mg}_{\mathrm{R}} / \mathrm{Mg} \mathrm{R}^{\prime}\right)+0.523\right)}+1\right]^{-1}
$$

2. Use relationships between elemental abundances in liquids and liquid $\mathrm{Mg} \# \mathrm{~s}$ to establish abundances in parental liquids. 
For the Southwest Indian Ridge, based on published and unpublished data,

$$
\begin{gathered}
\mathrm{Zr}_{\mathrm{L}}=-475 \mathrm{Mg}_{\mathrm{L}}+438.2, \\
\left(\mathrm{TiO}_{2}\right)_{\mathrm{L}}=-6.15 \mathrm{Mg}_{\mathrm{L}}+5.58, \\
\left(\mathrm{P}_{2} \mathrm{O}_{5}\right)_{\mathrm{L}}=-0.74 \mathrm{Mg}_{\mathrm{L}}+0.63, \\
\left(\mathrm{P}_{2} \mathrm{O}_{5}\right)_{\mathrm{L}}=-0.74 \mathrm{Mg}_{\mathrm{L}}+0.57
\end{gathered}
$$$$
\text { (Shaka Fracture Zone, Skaergaard). }
$$

3. Calculate excess $\mathrm{Zr}$. melt.

Let Excess $\mathrm{Zr}=\mathrm{Zr}$ in minerals crystallized from trapped residual

$$
\text { Excess } \begin{aligned}
\mathrm{Zr} & =\mathrm{Zr}_{\mathrm{R}}-\mathrm{Zr}_{\mathrm{cpx}}, \\
& =\left(\mathrm{Zr}_{\mathrm{R}}\right)-0.14\left(\mathrm{Zr}_{\mathrm{L}}\right)\left[\left(\mathrm{TiO}_{2}\right)_{\mathrm{R}} / 0.44\left(\mathrm{TiO}_{2}\right)_{\mathrm{L}}\right],
\end{aligned}
$$

where 0.14 is $D$ of $\mathrm{Zr}$ for clinopyroxene, and 0.44 is $D$ for $\mathrm{TiO}_{2}$. The ratio $\left(\mathrm{TiO}_{2}\right)_{\mathrm{R}} / 0.44\left(\mathrm{TiO}_{2}\right)_{\mathrm{L}}$ gives the fractional dilution of clinopyroxene by plagioclase plus olivine. Use this equation for both olivine gabbros and troctolites (assuming all $\mathrm{Zr}$ is in interstitial clinopyroxene, even in troctolites).

4. Calculate residual melt porosities.

$$
\begin{gathered}
\text { \% Porosity }(\mathrm{Zr})=100\left(\text { Excess } \mathrm{Zr} / \mathrm{Zr}_{\mathrm{L}}\right) . \\
\text { \% Porosity }\left(\mathrm{P}_{2} \mathrm{O}_{5}\right)=100\left[\left(\mathrm{P}_{2} \mathrm{O}_{5}\right)_{\mathrm{R}} /\left(\mathrm{P}_{2} \mathrm{O}_{5}\right)_{\mathrm{L}}\right] . \\
\text { Empirical Adjustment of } \mathrm{D}(\mathrm{Zr}) \text { for Clinopyroxene }
\end{gathered}
$$

Figure $\mathrm{Al}, \mathrm{TiO}_{2}$ vs. $\mathrm{Zr}$, shows how the $\mathrm{D}$ value for $\mathrm{Zr}$ was derived. The bold diagonal line through Leg 118 basalt compositions is given by Eqn. A1-3. The line labeled $\mathrm{D}(\mathrm{Zr})=0.20$ gives the calculated trend for clinopyroxene compositions crystallized from liquids with $1.5 \%$ to $3.0 \% \mathrm{TiO}_{2}$ using D values from Johnson et al. (1989), namely 0.20 for $\mathrm{Zr}$ and 0.44 for $\mathrm{TiO}_{2}$. Narrow diagonal lines to the origin give the effect of dilution on liquid and bulk gabbro compositions with plagioclase and olivine (D's $=0$ ). No gabbros should fall below a dilutioncontrol-line between clinopyroxene compositions and the origin. Clearly, many do if $\mathrm{D}(\mathrm{Zr})=0.20$. A better result is obtained using $\mathrm{D}(\mathrm{Zr})=0.14$, which trends through "zero-porosity" compositions defined using $\mathrm{P}_{2} \mathrm{O}_{5}$ contents.

Gabbro compositions plotting above the dilution control line between the clinopyroxene trend and the origin have excess $\mathrm{Zr}$, present in minerals crystallized from trapped residual melt. Points falling above the dilution control line between basalt liquids and the origin have excess $\mathrm{Zr}$ defined by interaction with silicic melts, which have high $\mathrm{Zr}$, but very low $\mathrm{TiO}_{2}$ contents. Points between the dilution

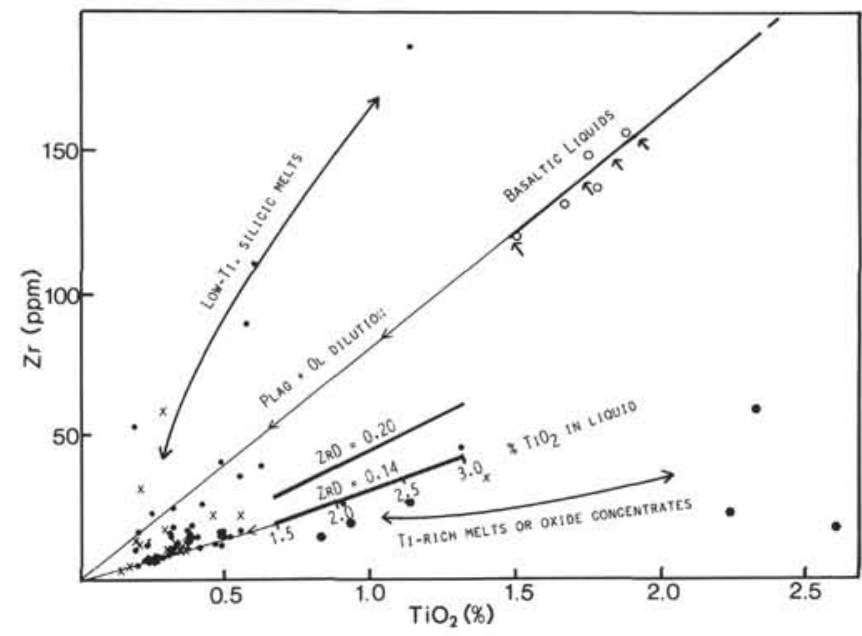

Figure $\mathrm{Al}$. $\mathrm{Zr}$ vs. $\mathrm{TiO}_{2}$ for gabbroic rocks from Hole 735B. Crosses $=$ olivine gabbros and disseminated oxide gabbros of lithologic Units 1 through VI; dots = olivine gabbros of lithologic Units V and VI. Circled dots $=$ oxide ferrogabbros of lithologic Units III and VI. In addition, more Ti-rich oxide ferrogabbros plot off the figure to the right. Large dots $=$ basalts from Sites 732 and 734, plus a basaltic dike from Hole 735B, recovered during Leg 118. Arrows next to the basalt liquid trend indicate estimated compositions of liquids that produced four high- $\mathrm{Mg} \#$ troctolites, the most primitive gabbroic rocks from Hole 735B (see Appendix A text for explanation of trend lines).

control lines linking the origin with basaltic liquids on the one hand, and clinopyroxenes on the other, are assumed to have some trapped basaltic melt, contributing to excess $\mathrm{Zr}$ abundances. The percentage of trapped melt in these is calculated using the procedure outlined above. Gabbro compositions plotting below the clinopyroxene trend line and its extrapolation to high $\mathrm{TiO}_{2}$ abundances are enriched in ilmenite and magnetite. Residual melt porosities cannot be calculated for these using $\mathrm{Zr}$ abundances.

\section{Calculation of Parental Sr}

Let $\mathrm{Sr}_{\mathrm{L}}, \mathrm{Sr}_{\mathrm{R}}$, and $\mathrm{Sr}_{\mathrm{FS}}$ equal strontium concentrations in liquid, rock, and plagioclase feldspar, respectively. From Figure 12 in the text, extrapolate $\mathrm{Sr}_{\mathrm{R}}$ along lines from the origin to the $\mathrm{FS}$ array.

Thus,

$$
\mathrm{Sr}_{\mathrm{FS}}=\left[1 /\left(\mathrm{Al}_{2} \mathrm{O}_{3} / \mathrm{Sr}_{\mathrm{R}}+0.236\right) \times 35.5,\right.
$$

and then,

$$
\mathrm{Sr}_{\mathrm{L}}=\mathrm{Sr}_{\mathrm{FS}} / 1.75 \text {, }
$$

where plagioclase $\mathrm{D}(\mathrm{Sr})=1.75$ (Morse, 1982). 
APPENDIX B

Silicate Mineral Analyses, Hole 735B

\begin{tabular}{|c|c|c|c|c|c|c|c|c|c|c|c|c|c|c|}
\hline Core/sect.: & 2D-1 & 2D-1 & 2D-1 & $2 \mathrm{D}-1$ & 2D-1 & $2 \mathrm{D}-1$ & $2 \mathrm{D}-1$ & $2 \mathrm{D}-1$ & $2 \mathrm{D}-1$ & $2 \mathrm{D}-1$ & $2 \mathrm{D}-1$ & 2D-1 & 3D-1 & 3D-1 \\
\hline Interval & $145-$ & $145-$ & $145-$ & $145-$ & 145 & $145-$ & $145-$ & $145-$ & $145-$ & 145 & $145-$ & 145 & $7-$ & $7-$ \\
\hline$(\mathrm{cm})$ : & 148 & 148 & 148 & 148 & 148 & 148 & 148 & 148 & 148 & 148 & 148 & 148 & 11 & 11 \\
\hline Analysis: & 1 & 2 & 3 & 4 & 5 & 6 & 7 & 8 & 9 & 10 & 11 & 12 & 13 & 14 \\
\hline Mineral: & PL-N & CPX-P & OPX & PL & OPX & CPX-P & OPX & PL & CPX-N & CPX-P & PL & CPX & AMPH & PL-N \\
\hline $\mathrm{SiO}_{2}$ & 54.60 & 51.34 & 49.19 & 55.28 & 51.45 & 51.21 & 51.15 & 57.66 & 51.48 & 50.37 & 58.06 & 51.15 & 43.40 & 56.34 \\
\hline $\mathrm{TiO}_{2}$ & - & 0.50 & 0.24 & - & 0.11 & 0.20 & 0.19 & - & 0.17 & 0.57 & - & 0.34 & 2.52 & - \\
\hline $\mathrm{Al}_{2} \mathrm{O}_{3}$ & 28.98 & 1.95 & 0.65 & 27.76 & 0.47 & 1.01 & 0.62 & 27.11 & 0.71 & 2.34 & 26.86 & 1.51 & 12.38 & 27.70 \\
\hline $\mathrm{Cr}_{2} \mathrm{O}_{3}$ & - & 0.00 & 0.00 & - & 0.02 & 0.05 & 0.00 & - & 0.05 & 0.00 & - & 0.03 & 0.02 & - \\
\hline $\mathrm{FeO}$ & 0.20 & 11.31 & 27.88 & 1.53 & 27.71 & 10.79 & 27.20 & 0.26 & 8.41 & 11.41 & 0.33 & 11.40 & 17.82 & 0.44 \\
\hline $\mathrm{MnO}$ & - & 0.41 & 0.75 & - & 0.80 & 0.39 & 0.78 & - & 0.37 & 0.37 & - & 0.40 & 0.23 & - \\
\hline $\mathrm{NiO}$ & - & 0.00 & 0.03 & - & 0.04 & 0.00 & 0.01 & - & 0.01 & 0.06 & - & 0.00 & 0.01 & - \\
\hline $\mathrm{MgO}$ & 0.00 & 13.01 & 17.92 & 0.19 & 18.49 & 13.06 & 18.40 & 0.00 & 13.91 & 12.55 & 0.00 & 13.25 & 10.38 & 0.02 \\
\hline $\mathrm{CaO}$ & 10.19 & 20.33 & 1.30 & 8.93 & 0.82 & 22.28 & 0.91 & 8.21 & 22.91 & 20.95 & 7.80 & 21.28 & 11.14 & 8.71 \\
\hline $\mathrm{Na}_{2} \mathrm{O}$ & 5.96 & 0.39 & - & 6.56 & - & 0.27 & - & 7.15 & 0.28 & 0.47 & 7.35 & 0.34 & 3.22 & 6.85 \\
\hline $\mathrm{K}_{2} \mathrm{O}$ & 0.04 & - & - & 0.07 & - & - & - & 0.13 & - & - & 0.14 & - & 0.28 & 0.08 \\
\hline Sum & 100.00 & 99.23 & 97.95 & 100.34 & 99.91 & 99.26 & 99.26 & 100.63 & 98.29 & 99.13 & 100.56 & 99.69 & 101.37 & 100.13 \\
\hline An & 48.6 & & & 42.9 & & & & 38.8 & & & 37.1 & & & 41.3 \\
\hline \multicolumn{15}{|l|}{ Fo } \\
\hline Wo & & 43.0 & 2.7 & & 1.7 & 45.6 & 1.9 & & 46.9 & 44.3 & & 43.8 & & \\
\hline En & & 38.3 & 51.9 & & 53.4 & 37.2 & 53.6 & & 39.6 & 36.9 & & 37.9 & & \\
\hline Fs & & 18.7 & 45.4 & & 44.9 & 17.2 & 44.5 & & 13.4 & 18.8 & & 18.3 & & \\
\hline
\end{tabular}

\begin{tabular}{|c|c|c|c|c|c|c|c|c|c|c|c|c|c|c|}
\hline Core/sect.: & 3D-1 & $3 \mathrm{D}-1$ & $3 \mathrm{D}-1$ & $16 \mathrm{R}=5$ & $16 R-5$ & $16 R-5$ & $16 \mathrm{R}-5$ & $16 \mathrm{R}-5$ & $16 R-5$ & $16 \mathrm{R}-5$ & 23R-1 & 23R-1 & 23R-1 & 23R-1 \\
\hline Interval & $7-$ & 7. & 7. & $47-$ & $47-$ & 47. & $47-$ & 47. & $47-$ & $47-$ & $47-$ & 46- & $46-$ & 46- \\
\hline (cm): & 11 & 11 & 11 & 51 & 51 & 51 & 51 & 51 & 51 & 51 & 51 & 53 & 53 & 53 \\
\hline Analysis: & 15 & 16 & 17 & 18 & 19 & 20 & 21 & 22 & 23 & 24 & 25 & 26 & 27 & 28 \\
\hline Mineral: & AMPH & PL-N & PL-P & $\mathrm{OL}$ & PL & CPX & CPX & CPX & CPX & PL & CPX & CPX & PL & OPX \\
\hline $\mathrm{SiO}_{2}$ & 42.00 & 55.73 & 57.13 & 39.40 & 51.15 & 52.23 & 52.80 & 53.36 & 53.15 & 51.35 & 52.65 & 50.93 & 57.27 & 51.65 \\
\hline $\mathrm{TiO}_{2}$ & 3.06 & - & - & - & - & 0.61 & 0.60 & 0.44 & 0.61 & - & - & 0.70 & - & 0.34 \\
\hline $\mathrm{Al}_{2} \mathrm{O}_{3}$ & 12.07 & 27.46 & 27.76 & - & 29.79 & 3.34 & 3.02 & 2.13 & 2.52 & 31.48 & 3.39 & 2.10 & 27.83 & 1.07 \\
\hline $\mathrm{Cr}_{2} \mathrm{O}_{3}$ & 0.03 & - & - & 0.00 & - & 0.67 & 0.60 & 0.66 & 0.61 & - & 0.66 & 0.00 & - & 0.01 \\
\hline $\mathrm{FeO}$ & 16.83 & 0.12 & 0.12 & 18.33 & 0.12 & 4.70 & 5.20 & 4.02 & 4.08 & 0.06 & 4.79 & 11.18 & 0.18 & 22.32 \\
\hline $\mathrm{MnO}$ & 0.25 & - & - & 0.27 & - & 0.17 & 0.11 & 0.17 & 0.17 & - & 0.16 & 0.32 & - & 0.62 \\
\hline $\mathrm{NiO}$ & 0.03 & - & - & 0.15 & - & 0.04 & 0.01 & 0.03 & 0.06 & - & 0.00 & 0.01 & - & 0.07 \\
\hline $\mathrm{MgO}$ & 10.07 & 0.00 & 0.00 & 43.05 & 0.00 & 16.28 & 17.68 & 16.47 & 16.34 & 0.00 & 16.56 & 13.77 & 0.00 & 21.67 \\
\hline $\mathrm{CaO}$ & 11.60 & 8.68 & 8.89 & 0.04 & 13.58 & 21.75 & 19.57 & 23.15 & 23.30 & 13.96 & 22.17 & 20.38 & 8.52 & 1.56 \\
\hline $\mathrm{Na}_{2} \mathrm{O}$ & 3.06 & 6.20 & 6.75 & - & 3.99 & 0.61 & 0.42 & 0.39 & 0.46 & 3.81 & 0.54 & 0.41 & 6.96 & - \\
\hline $\mathrm{K}_{2} \mathrm{O}$ & 0.31 & 0.13 & 0.06 & - & 0.05 & - & - & - & - & 0.04 & - & - & 0.08 & - \\
\hline Sum & 98.56 & 98.32 & 100.72 & 101.24 & 98.68 & 100.40 & 100.07 & 100.94 & 101.80 & 100.70 & 101.51 & 99.80 & 100.84 & 99.31 \\
\hline An & & 43.6 & 43.6 & & 65.3 & & & & & 66.9 & & & 40.3 & \\
\hline Fo & & & 80.7 & & & & & & & & & & & \\
\hline Wo & & & & & & 45.3 & 40.6 & 47.0 & 47.4 & & 45.3 & 42.2 & & 3.2 \\
\hline En & & & & & & 47.1 & 51.0 & 46.6 & 46.2 & & 47.1 & 39.7 & & 61.4 \\
\hline Fs & & & & & & 7.6 & 8.4 & 6.4 & 6.5 & & 7.6 & 18.1 & & 35.5 \\
\hline
\end{tabular}

\begin{tabular}{|c|c|c|c|c|c|c|c|c|c|c|c|c|c|c|}
\hline Core/sect.: & $35 \mathrm{R}-1$ & $35 \mathrm{R}-1$ & $35 \mathrm{R}-1$ & $35 \mathrm{R}-1$ & $35 \mathrm{R}-1$ & $35 \mathrm{R}-1$ & $35 \mathrm{R}-1$ & $35 \mathrm{R}-1$ & $35 \mathrm{R}-1$ & $35 \mathrm{R}-1$ & $35 \mathrm{R}-1$ & $35 \mathrm{R}-1$ & $35 \mathrm{R}-1$ & 35R-1 \\
\hline Interval & $45-$ & $45-$ & $45-$ & 45 & $45-$ & $45-$ & 45 & $45-$ & $45-$ & $45-$ & $45-$ & $45-$ & $45-$ & $45-$ \\
\hline$(\mathrm{cm}):$ & 47 & 47 & 47 & 47 & 47 & 47 & 47 & 47 & 47 & 47 & 47 & 47 & 47 & 47 \\
\hline Analysis: & 29 & 30 & 31 & 32 & 33 & 34 & 35 & 36 & 37 & 38 & 39 & 40 & 41 & 42 \\
\hline Mineral: & CPX & PL & $\mathrm{OL}$ & OPX & CPX & PL & CPX & PL & CPX & CPX & PL & CPX & CPX & CPX \\
\hline $\mathrm{SiO}_{2}$ & 51.34 & 51.90 & 37.60 & 52.77 & 52.02 & 52.66 & 52.14 & 58.54 & 50.59 & 50.20 & 55.17 & 51.83 & 51.79 & 51.89 \\
\hline $\mathrm{TiO}_{2}$ & 0.55 & - & - & 0.35 & 0.46 & - & 0.73 & - & 0.63 & 1.02 & - & 0.88 & 0.55 & 0.22 \\
\hline $\mathrm{Al}_{2} \mathrm{O}_{3}$ & 3.01 & 30.43 & - & 0.82 & 1.48 & 30.65 & 2.86 & 28.60 & 1.83 & 3.04 & 28.32 & 2.38 & 3.42 & 3.14 \\
\hline $\mathrm{Cr}_{2} \mathrm{O}_{3}$ & 0.30 & - & 0.02 & 0.01 & 0.04 & - & 0.41 & - & 0.05 & 0.31 & - & 0.14 & 0.34 & 0.15 \\
\hline $\mathrm{FeO}$ & 6.97 & 0.15 & 29.32 & 24.84 & 15.50 & 0.10 & 5.92 & 0.18 & 12.12 & 9.40 & 0.23 & 8.49 & 5.36 & 7.50 \\
\hline $\mathrm{MnO}$ & 0.20 & - & 0.48 & 0.35 & 0.47 & - & 0.22 & - & 0.38 & 0.26 & - & 0.29 & 0.21 & 0.22 \\
\hline $\mathrm{NiO}$ & 0.00 & - & 0.12 & 0.00 & 0.01 & - & 0.04 & - & 0.03 & 0.06 & - & 0.01 & 0.06 & 0.07 \\
\hline $\mathrm{MgO}$ & 16.66 & 0.00 & 33.40 & 21.12 & 14.95 & 0.00 & 15.82 & 0.00 & 13.09 & 14.17 & 0.00 & 15.11 & 15.53 & 16.69 \\
\hline $\mathrm{CaO}$ & 19.80 & 13.38 & 0.03 & 1.34 & 14.74 & 12.99 & 21.84 & 7.60 & 19.93 & 20.77 & 10.74 & 20.46 & 22.56 & 18.77 \\
\hline $\mathrm{Na}_{2} \mathrm{O}$ & 0.55 & 4.20 & - & - & 0.29 & 4.34 & 0.39 & 7.60 & 0.55 & 0.48 & 5.75 & 0.33 & 0.49 & 0.40 \\
\hline $\mathrm{K}_{2} \mathrm{O}$ & - & 0.04 & - & - & - & 0.04 & - & 0.03 & - & - & 0.04 & - & & - \\
\hline Sum & 99.36 & 100.11 & 100.97 & 100.97 & 99.96 & 100.78 & 100.36 & 99.22 & 99.18 & 99.70 & 100.24 & 99.92 & 100.31 & 99.72 \\
\hline An & & 63.8 & & & & 62.3 & & 36.7 & & & 50.8 & & & \\
\hline Fo & & & 67.0 & & & & & & & & & & & \\
\hline Wo & 40.9 & & & 2.5 & 30.9 & & 45.1 & & 41.9 & 43.4 & & 42.5 & 46.7 & 39.3 \\
\hline En & 47.9 & & & 57.5 & 43.8 & & 45.4 & & 38.3 & 41.2 & & 43.7 & 44.7 & 48.5 \\
\hline Fs & 11.2 & & & 39.8 & 25.2 & & 9.5 & & 19.9 & 15.3 & & 13.8 & 8.6 & 12.2 \\
\hline
\end{tabular}


APPENDIX B

Silicate Mineral Analyses, Hole 735B

\begin{tabular}{|c|c|c|c|c|c|c|c|c|c|c|c|c|c|c|}
\hline Core/sect.: & $35 \mathrm{R}-1$ & $35 R-1$ & $35 R-1$ & $35 \mathrm{R}-1$ & $41 R-4$ & $41 R-4$ & $41 R-4$ & $41 R-4$ & $41 \mathrm{R}-4$ & $41 R-4$ & $41 R-4$ & $41 R-4$ & $41 R-4$ & $41 R-4$ \\
\hline $\begin{array}{l}\text { Interval } \\
(\mathrm{cm}) \text { : }\end{array}$ & $\begin{array}{c}45- \\
47\end{array}$ & $\begin{array}{l}45- \\
47\end{array}$ & $\begin{array}{l}45- \\
47\end{array}$ & $\begin{array}{l}45- \\
47\end{array}$ & $\begin{array}{c}68- \\
70\end{array}$ & $\begin{array}{l}68- \\
70\end{array}$ & $\begin{array}{c}68- \\
70\end{array}$ & $\begin{array}{l}68- \\
70\end{array}$ & $\begin{array}{l}68- \\
70\end{array}$ & $\begin{array}{l}68- \\
70\end{array}$ & $\begin{array}{c}68- \\
70\end{array}$ & $\begin{array}{c}68- \\
70\end{array}$ & $\begin{array}{c}68- \\
70\end{array}$ & $\begin{array}{l}68- \\
70\end{array}$ \\
\hline Analysis: & 43 & 44 & 45 & 46 & 47 & 48 & 49 & 50 & 51 & 52 & 53 & 54 & 55 & 56 \\
\hline Mineral: & CPX & PIG & CPX & $\mathrm{CPZ}$ & OPX & PL & OL & OPX & CPX & PL & AMPH & OL & PL & CPX \\
\hline $\mathrm{SiO}_{2}$ & 52.50 & 53.15 & 51.74 & 52.13 & 53.14 & 56.15 & 36.58 & 52.76 & 51.68 & 55.97 & 42.84 & 36.29 & 56.31 & 50.31 \\
\hline $\mathrm{TiO}_{2}$ & 0.75 & 0.29 & 1.00 & 0.81 & 0.14 & - & - & 0.44 & 0.60 & - & 1.83 & - & - & 0.69 \\
\hline $\mathrm{Al}_{2} \mathrm{O}_{3}$ & 2.22 & 1.05 & 3.05 & 2.85 & 1.03 & 27.58 & - & 1.04 & 2.23 & 27.41 & 12.71 & - & 28.18 & 2.35 \\
\hline $\mathrm{Cr}_{2} \mathrm{O}_{3}$ & 0.00 & 0.06 & 0.11 & 0.19 & 0.00 & - & 0.00 & 0.02 & 0.00 & - & 0.01 & 0.00 & - & 0.01 \\
\hline $\mathrm{FeO}$ & 6.04 & 0.12 & 5.81 & 6.57 & 19.80 & 0.81 & 33.71 & 20.91 & 9.16 & 0.17 & 11.40 & 35.10 & 0.22 & 9.03 \\
\hline $\mathrm{MnO}$ & 0.23 & 0.36 & 0.20 & 0.19 & 0.59 & - & 0.54 & 0.58 & 0.33 & - & 0.18 & 0.60 & - & 0.32 \\
\hline $\mathrm{NiO}$ & 0.00 & 0.03 & 0.05 & 0.00 & 0.02 & - & 0.01 & 0.00 & 0.05 & - & 0.00 & 0.05 & - & 0.01 \\
\hline $\mathrm{MgO}$ & 15.88 & 24.38 & 15.35 & 16.49 & 24.09 & 0.01 & 0.08 & 23.35 & 14.52 & 0.00 & 14.47 & 28.96 & 0.00 & 14.80 \\
\hline $\mathrm{CaO}$ & 23.01 & 8.00 & 23.28 & 21.37 & 1.03 & 9.61 & 30.04 & 0.87 & 21.25 & 9.80 & 11.56 & 0.02 & 9.28 & 21.11 \\
\hline $\mathrm{Na}_{2} \mathrm{O}$ & 0.37 & 0.12 & 0.34 & 0.32 & - & 6.31 & - & - & 0.44 & 6.11 & 2.51 & - & 6.47 & 0.36 \\
\hline $\mathrm{K}_{2} \mathrm{O}$ & - & - & - & - & - & 0.08 & - & - & - & 0.13 & 0.25 & - & 0.10 & - \\
\hline Sum & 101.02 & 98.62 & 100.98 & 100.99 & 100.06 & 99.96 & 100.98 & 99.97 & 100.27 & 99.58 & 97.76 & 101.02 & 100.55 & 98.99 \\
\hline An & & & & & & 45.7 & & & & 47.0 & & & 44.2 & \\
\hline Fo & & & & & & & 61.4 & & & & & 59.5 & & \\
\hline Wo & 46.2 & 15.8 & 47.4 & 43.2 & & & & 1.8 & 43.7 & & & & & 43.3 \\
\hline En & 44.3 & 67.0 & 43.1 & 46.4 & & & & 65.4 & 41.8 & & & & & 42.3 \\
\hline FS & 9.5 & 17.2 & 9.2 & 10.4 & & & & 32.9 & 14.7 & & & & & 14.4 \\
\hline
\end{tabular}

\begin{tabular}{|c|c|c|c|c|c|c|c|c|c|c|c|c|c|c|}
\hline $\begin{array}{l}\text { Core/sect.: } \\
\text { Interval } \\
\text { (cm): } \\
\text { Analysis: } \\
\text { Mineral: }\end{array}$ & $\begin{array}{c}41 \mathrm{R}-4 \\
68- \\
70 \\
57 \\
\text { OL }\end{array}$ & $\begin{array}{c}41 \mathrm{R}-4 \\
68- \\
70 \\
58 \\
\text { OPX }\end{array}$ & $\begin{array}{c}41 \mathrm{R}-4 \\
68- \\
70 \\
59 \\
\text { CPX }\end{array}$ & $\begin{array}{c}41 \mathrm{R}-4 \\
68- \\
70 \\
60 \\
\mathrm{OL}\end{array}$ & $\begin{array}{c}414-4 \\
68- \\
70 \\
61 \\
\text { PL }\end{array}$ & $\begin{array}{c}41 \mathrm{R}-4 \\
68- \\
70 \\
62 \\
\mathrm{OL}\end{array}$ & $\begin{array}{c}41 \mathrm{R}-4 \\
68- \\
70 \\
63 \\
\mathrm{OL}\end{array}$ & $\begin{array}{c}41 \mathrm{R}-4 \\
68- \\
70 \\
64 \\
\text { CPX }\end{array}$ & $\begin{array}{c}41 \mathrm{R}-4 \\
68- \\
70 \\
65 \\
\mathrm{OL}\end{array}$ & $\begin{array}{c}41 \mathrm{R}-4 \\
68- \\
70 \\
66 \\
\mathrm{OL}\end{array}$ & $\begin{array}{c}41 \mathrm{R}-4 \\
68- \\
70 \\
67 \\
\text { CPX }\end{array}$ & $\begin{array}{c}41 \mathrm{R}-4 \\
68- \\
70 \\
68 \\
\mathrm{PL}\end{array}$ & $\begin{array}{c}44 \mathrm{R}-2 \\
6- \\
8 \\
69 \\
\text { OPX }\end{array}$ & $\begin{array}{c}44 \mathrm{R}-2 \\
6- \\
8 \\
70 \\
\text { OPX }\end{array}$ \\
\hline $\mathrm{SiO}_{2}$ & 36.35 & 52.89 & 51.46 & 36.12 & 56.15 & 36.59 & 36.94 & 50.98 & 36.35 & 36.71 & 51.43 & 56.41 & 51.94 & 51.39 \\
\hline $\mathrm{TiO}_{2}$ & - & 0.21 & 0.68 & - & - & - & - & 0.83 & - & - & 0.82 & - & 0.29 & 0.41 \\
\hline $\mathrm{Al}_{2} \mathrm{O}_{3}$ & - & 1.02 & 2.20 & - & 28.47 & - & - & 2.62 & - & - & 2.79 & 28.53 & 0.92 & 0.87 \\
\hline $\mathrm{Cr}_{2} \mathrm{O}_{3}$ & 0.03 & 0.02 & 0.03 & 0.03 & - & 0.02 & 0.03 & 0.01 & 0.00 & 0.02 & 0.02 & - & 0.00 & 0.05 \\
\hline $\mathrm{FeO}$ & 34.32 & 19.64 & 9.17 & 33.99 & 0.21 & 33.49 & 32.77 & 8.64 & 35.08 & 34.74 & 10.40 & 0.19 & 22.75 & 23.95 \\
\hline $\mathrm{MnO}$ & 0.60 & 0.48 & 0.26 & 0.61 & - & 0.68 & 0.93 & 0.28 & 0.55 & 0.67 & 0.33 & - & 0.75 & 0.73 \\
\hline $\mathrm{NiO}$ & 0.08 & 0.03 & 0.08 & 0.08 & - & 0.04 & 0.02 & 0.02 & 0.03 & 0.01 & 0.01 & - & 0.00 & 0.04 \\
\hline $\mathrm{MgO}$ & 29.35 & 23.79 & 14.51 & 29.97 & 0.00 & 29.79 & 29.26 & 14.08 & 29.40 & 29.26 & 14.25 & 0.00 & 22.68 & 21.68 \\
\hline $\mathrm{CaO}$ & 0.07 & 0.98 & 21.65 & 0.08 & 9.62 & 0.15 & 0.39 & 21.98 & 0.06 & 0.04 & 20.77 & 9.82 & 1.20 & 1.34 \\
\hline $\mathrm{Na}_{2} \mathrm{O}$ & - & - & 0.43 & - & 6.27 & - & - & 0.51 & - & - & 0.42 & 6.15 & - & - \\
\hline $\mathrm{K}_{2} \mathrm{O}$ & - & - & - & - & 0.11 & - & & - & - & - & - & 0.08 & - & - \\
\hline Sum & 100.80 & 99.05 & 100.46 & 100.88 & 100.82 & 100.78 & 100.42 & 99.95 & 101.46 & 101.46 & 101.23 & 101.17 & 100.53 & 100.46 \\
\hline An & & & & & 45.9 & & & & & & & 46.9 & & \\
\hline Fo & 60.4 & & & 61.1 & & 61.3 & 61.4 & & 59.9 & 60.0 & & & & \\
\hline Wo & & 2.0 & 44.2 & & & & & 45.5 & & & 42.6 & & 2.4 & 2.7 \\
\hline En & & 67.0 & 41.8 & & & & & 40.6 & & & 40.7 & & 62.5 & 60.5 \\
\hline Fs & & 31.0 & 14.6 & & & & & 13.9 & & & 16.6 & & 35.2 & 36.9 \\
\hline
\end{tabular}

\begin{tabular}{|c|c|c|c|c|c|c|c|c|c|c|c|c|c|c|}
\hline Core/sect.: & $44 \mathrm{R}-2$ & $44 \mathrm{R}-2$ & $44 \mathrm{R}-2$ & $44 \mathrm{R}-2$ & $44 \mathrm{R}-2$ & $47 R-2$ & $47 \mathrm{R}-2$ & $47 \mathrm{R}-2$ & $49 \mathrm{R}-2$ & $49 \mathrm{R}-2$ & $49 \mathrm{R}-2$ & $49 \mathrm{R}-2$ & $49 \mathrm{R}-2$ & $49 \mathrm{R}-2$ \\
\hline $\begin{array}{l}\text { Interval: } \\
\text { (cm): }\end{array}$ & 6- & $\begin{array}{l}6- \\
8\end{array}$ & $\begin{array}{l}6- \\
8\end{array}$ & $\begin{array}{l}6- \\
8\end{array}$ & 6- & $31-$ & $31-$ & $31-$ & 89- & 89- & 89- & 89- & 89.- & 89- \\
\hline Analysis: & 71 & 72 & 73 & 74 & 75 & 76 & 77 & $\begin{array}{l}30 \\
78\end{array}$ & $\begin{array}{l}91 \\
79\end{array}$ & $\begin{array}{l}91 \\
80\end{array}$ & $\begin{array}{l}91 \\
81\end{array}$ & $\begin{array}{l}91 \\
82\end{array}$ & $\begin{array}{l}71 \\
83\end{array}$ & 84 \\
\hline Mineral: & PL & OPX & PIG & CPX & PL & PL & PL & CPX & OPX & CPX & PL & CPX & OPX & CPX \\
\hline $\mathrm{SiO}_{2}$ & 58.01 & 51.94 & 51.36 & 58.62 & 57.55 & 58.04 & & 50.23 & 51.78 & 52.36 & 58.86 & 52.27 & 51.14 & 51.49 \\
\hline $\mathrm{TiO}_{2}$ & - & 0.36 & 0.34 & 0.80 & - & - & - & 0.81 & 0.30 & 0.44 & - & 0.40 & 0.28 & 0.72 \\
\hline $\mathrm{Al}_{2} \mathrm{O}_{3}$ & 26.81 & 0.91 & 1.35 & 2.53 & 26.62 & 25.76 & 25.79 & 2.24 & 1.07 & 1.67 & 26.65 & 1.55 & 0.96 & 2.36 \\
\hline $\mathrm{Cr}_{2} \mathrm{O}_{3}$ & - & 0.02 & 0.02 & 0.00 & - & - & - & 0.04 & 0.00 & 0.04 & - & 0.00 & 0.00 & 0.06 \\
\hline $\mathrm{FeO}$ & 0.28 & 23.95 & 21.22 & 10.70 & 0.16 & 0.12 & 0.30 & 11.72 & 24.85 & 10.08 & 0.11 & 10.15 & 23.83 & 12.26 \\
\hline $\mathrm{MnO}$ & - & 0.71 & 0.73 & 0.36 & - & - & - & 0.36 & 0.64 & 0.32 & - & 0.37 & 0.66 & 0.36 \\
\hline $\mathrm{NiO}$ & - & 0.00 & 0.06 & 0.00 & - & - & - & 0.00 & 0.01 & 0.04 & - & 0.00 & 0.01 & 0.03 \\
\hline $\mathrm{MgO}$ & 0.01 & 21.40 & 19.20 & 13.39 & 0.01 & 0.00 & 0.00 & 13.56 & 20.09 & 13.95 & 0.00 & 13.99 & 20.70 & 13.98 \\
\hline $\mathrm{CaO}$ & 8.08 & 1.97 & 5.09 & 20.82 & 7.96 & 7.60 & 7.43 & 19.16 & 2.36 & 20.92 & 7.41 & 21.17 & 2.84 & 19.04 \\
\hline $\mathrm{Na}_{2} \mathrm{O}$ & 6.68 & - & - & 0.53 & 6.97 & 7.23 & 7.34 & - & - & 0.39 & 7.10 & 0.37 & - & 0.48 \\
\hline $\mathrm{K}_{2} \mathrm{O}$ & 0.14 & - & - & - & 0.15 & 0.09 & 0.10 & - & - & - & 0.11 & - & - & - \\
\hline Sum & 100.01 & 101.26 & 99.77 & 100.50 & 100.46 & 98.38 & 99.01 & 98.66 & 101.10 & 100.19 & 99.86 & 100.27 & 100.42 & 100.78 \\
\hline An & 40.1 & & & & 38.7 & 36.7 & 35.8 & & & & 36.6 & & & \\
\hline \multicolumn{15}{|l|}{ Fo } \\
\hline Wo & & 3.9 & 10.5 & 43.6 & & & & 40.6 & 4.8 & 43,4 & & 43.6 & 5.7 & 39.6 \\
\hline Fn & & 59.0 & 55.2 & 39.0 & & & & 40.0 & 56.2 & 40.3 & & 40.1 & 57.3 & 40.5 \\
\hline Fs & & 37.1 & 34.3 & 17.5 & & & & 19.4 & 39.0 & 16.3 & & 16.3 & 37.0 & 19.9 \\
\hline
\end{tabular}


APPENDIX B

Silicate Mineral Analyses, Hole 735B

\begin{tabular}{|c|c|c|c|c|c|c|c|c|c|c|c|c|c|c|}
\hline Core/sect.: & $49 \mathrm{R}-2$ & $49 \mathrm{R}-2$ & $49 \mathrm{R}-2$ & $49 \mathrm{R}-2$ & $52 \mathrm{R}-4$ & $52 R-4$ & $52 R-4$ & $52 R-4$ & $52 \mathrm{R}-4$ & $52 R-4$ & $524-4$ & $52 \mathrm{R}-4$ & $53 R-4$ & $53 \mathrm{R}-4$ \\
\hline Interval: & 89. & 89- & $69-$ & 69- & 69. & $69-$ & 69. & 69. & 69- & 69. & 69- & $69-$ & 68- & 68- \\
\hline$(\mathrm{cm}):$ & 91 & 91 & 71 & 71 & 71 & 71 & 71 & 71 & 71 & 71 & 71 & 71 & 78 & 78 \\
\hline Analysis: & 85 & 86 & 87 & 88 & 89 & 90 & 91 & 92 & 93 & 94 & 95 & 96 & 97 & 98 \\
\hline Mineral: & OPX & CPX & PL & CPX & $\mathrm{OL}$ & CPX & PL & AMPH & PL & CPX & CPX & CPX & OPX & CPX \\
\hline $\mathrm{SiO}_{2}$ & 51.35 & 52.08 & 58.84 & 51.11 & 32.97 & 50.16 & 57.69 & 41.88 & 58.26 & 49.65 & 49.60 & 49.97 & 50.36 & 52.19 \\
\hline $\mathrm{TiO}_{2}^{2}$ & 0.29 & 0.76 & - & 0.7 & - & 0.48 & - & 2.36 & - & 0.69 & 0.54 & 0.63 & 0.09 & 0.10 \\
\hline $\mathrm{Al}_{2} \mathrm{O}_{3}$ & 1.02 & 2.08 & 26.23 & 2.18 & - & 1.27 & 25.78 & 11.10 & 26.00 & 1.78 & 1.78 & 1.74 & 0.15 & 0.40 \\
\hline $\mathrm{Cr}_{2} \mathrm{O}_{3}$ & 0.03 & 0.03 & - & 0.04 & 0.00 & 0.00 & - & 0.05 & - & 0.00 & 0.01 & 0.03 & 0.00 & 0.03 \\
\hline $\mathrm{FeO}$ & 25.34 & 11.51 & 0.29 & 11.06 & 49.70 & 19.96 & 0.23 & 17.11 & 0.10 & 13.47 & 13.64 & 16.61 & 32.46 & 13.80 \\
\hline $\mathrm{MnO}$ & 0.75 & 0.40 & - & 0.36 & 0.94 & 0.56 & - & 0.20 & - & 0.49 & 0.51 & 0.55 & 1.05 & 0.56 \\
\hline $\mathrm{NiO}$ & 0.00 & 0.00 & - & 0.00 & 0.07 & 0.00 & - & 0.03 & - & 0.00 & 0.06 & 0.02 & 0.08 & 0.01 \\
\hline $\mathrm{MgO}$ & 20.76 & 13.77 & 0.00 & 13.44 & 16.11 & 13.65 & 0.00 & 10.36 & 0.00 & 11.66 & 11.92 & 12.78 & 14.78 & 11.91 \\
\hline $\mathrm{CaO}$ & 0.97 & 19.97 & 7.28 & 20.70 & 0.07 & 12.36 & 7.04 & 11.18 & 7.08 & 20.31 & 19.65 & 16.36 & 1.24 & 21.47 \\
\hline $\mathrm{Na}_{2} \mathrm{O}$ & - & 0.49 & 7.44 & 0.53 & - & 0.27 & 7.77 & 2.68 & 7.83 & 0.43 & 0.38 & 0.43 & - & 0.33 \\
\hline $\mathrm{K}_{2} \mathrm{O}$ & - & - & 0.07 & - & - & - & 0.08 & 0.18 & 0.11 & - & - & - & - & - \\
\hline Sum & 100.51 & 101.09 & 100.14 & 100.14 & 99.85 & 98.72 & 98.62 & 97.15 & 99.37 & 98.48 & 98.08 & 99.13 & 100.20 & 100.80 \\
\hline An & & & 35.1 & & & & 33.3 & & 33.3 & & & & & \\
\hline Fo & & & & & 36.6 & & & & & & & & & \\
\hline Wo & 2.0 & 41.5 & & 43.1 & & 26.3 & & & & 43.2 & 41.9 & 34.7 & 2.6 & 44.0 \\
\hline Fn & 58.2 & 39.8 & & 38.9 & & 40.5 & & & & 34.5 & 35.4 & 37.7 & 43.6 & 33.9 \\
\hline Fs & 39.9 & 18.7 & & 18.0 & & 33.2 & & & & 22.4 & 22.7 & 27.5 & 53.8 & 22.1 \\
\hline
\end{tabular}

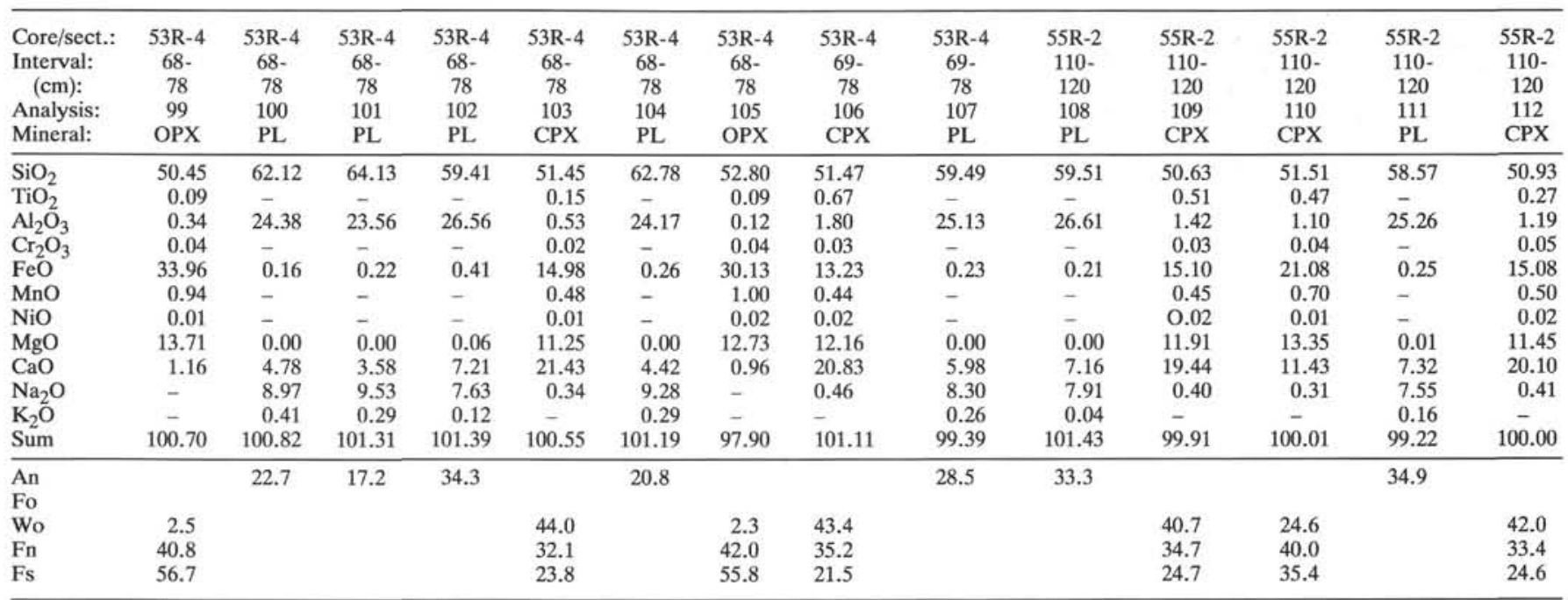

\begin{tabular}{|c|c|c|c|c|c|c|c|c|c|c|c|c|c|c|}
\hline Core/sect.: & $55 \mathrm{R}-2$ & $55 \mathrm{R}-2$ & $55 \mathrm{R}-2$ & $55 \mathrm{R}-2$ & $69 \mathrm{R}-4$ & $69 \mathrm{R}-4$ & $69 \mathrm{R}-4$ & $69 \mathrm{R}-4$ & $69 \mathrm{R}-4$ & $73 R-5$ & $73 R-5$ & $73 R-5$ & $73 R-5$ & $73 R-5$ \\
\hline Interval: & $110-$ & $110-$ & $110-$ & $110-$ & $138-$ & $138-$ & $138-$ & $138-$ & $138-$ & $74-$ & 74- & 74- & 74- & $74-$ \\
\hline$(\mathrm{cm}):$ & 120 & 120 & 120 & 120 & 145 & 145 & 145 & 145 & 145 & 78 & 78 & 78 & 78 & 78 \\
\hline Analysis: & 113 & 114 & 115 & 116 & 117 & 118 & 119 & 120 & 121 & 122 & 123 & 124 & 125 & 126 \\
\hline Mineral: & $\mathrm{OL}$ & $\mathrm{OL}$ & CPX & CPX & $\mathrm{OL}$ & CPX & PL & OPX & CPX & PL & PL & CPX & OPX & CPX \\
\hline $\mathrm{SiO}_{2}$ & 33.51 & 33.69 & 51.40 & 52.04 & 38.69 & 51.97 & 51.77 & 54.40 & 51.75 & 59.08 & 59.27 & 51.20 & 50.78 & 51.73 \\
\hline $\mathrm{TiO}_{2}^{2}$ & - & - & 0.57 & 0.28 & - & 0.63 & - & 0.47 & 0.99 & - & - & 0.63 & 0.33 & 0.52 \\
\hline $\mathrm{Al}_{2} \mathrm{O}_{3}$ & - & - & 1.79 & 1.27 & - & 2.99 & 30.59 & 1.67 & 3.25 & 25.51 & 25.72 & 1.82 & 0.87 & 1.51 \\
\hline $\mathrm{Cr}_{2} \mathrm{O}_{3}$ & 0.03 & 0.01 & 0.05 & 0.01 & 0.03 & 0.15 & - & 0.17 & 0.19 & - & - & 0.00 & 0.00 & 0.00 \\
\hline $\mathrm{FeO}$ & 47.14 & 50.28 & 13.71 & 13.28 & 21.75 & 6.56 & 0.21 & 14.80 & 5.60 & 0.24 & 0.35 & 11.48 & 23.37 & 10.59 \\
\hline $\mathrm{MnO}$ & 0.99 & 1.00 & 0.49 & 0.46 & 0.34 & 0.23 & - & 0.44 & 0.21 & - & - & 0.49 & 0.78 & 0.38 \\
\hline $\mathrm{NiO}$ & 0.04 & 0.07 & 0.03 & 0.07 & 0.09 & 0.04 & - & 0.05 & 0.00 & - & - & 0.00 & 0.04 & 0.00 \\
\hline $\mathrm{MgO}$ & 17.43 & 16.09 & 11.95 & 11.90 & 40.46 & 17.10 & 0.02 & 27.77 & 15.16 & 0.00 & 0.00 & 13.42 & 20.77 & 13.83 \\
\hline $\mathrm{CaO}$ & 0.10 & 0.09 & 20.30 & 21.56 & 0.07 & 20.73 & 12.93 & 1.11 & 23.79 & 6.81 & 6.90 & 20.43 & 2.16 & 21.35 \\
\hline $\mathrm{Na}_{2} \mathrm{O}$ & - & - & 0.51 & 0.39 & - & 0.36 & 4.41 & - & 0.34 & 7.35 & 7.57 & 0.48 & - & 0.41 \\
\hline $\mathrm{K}_{2} \mathrm{O}$ & - & - & - & - & - & - & 0.01 & - & - & 0.15 & 0.09 & - & - & - \\
\hline Sum & 99.24 & 101.15 & 100.81 & 101.25 & 101.42 & 100.77 & 99.99 & 100.92 & 101.26 & 99.15 & 99.91 & 99.96 & 99.10 & 100.33 \\
\hline An & & & & & & & 61.8 & & & 33.9 & 33.5 & & & \\
\hline Fo & 39.7 & 36.3 & & & 76.5 & & & & & & & & & \\
\hline Wo & & & 42.6 & 44.5 & & 41.7 & & 2.2 & 30.9 & & & 42.5 & 4.4 & 43.6 \\
\hline Fn & & & 34.9 & 34.1 & & 47.9 & & 75.3 & 43.8 & & & 38.9 & 58.6 & 39.4 \\
\hline Fs & & & 22.5 & 21.4 & & 10.6 & & 22.5 & 25.2 & & & 18.6 & 37.0 & 16.9 \\
\hline
\end{tabular}


APPENDIX B

Silicate Mineral analyses, Hole 735B

\begin{tabular}{|c|c|c|c|c|c|c|c|c|c|c|c|c|c|c|}
\hline Core/sect.: & $74 \mathrm{R}-6$ & 74R-6 & $74 R-6$ & $74 \mathrm{R}-6$ & $77 \mathrm{R}-4$ & $77 R-4$ & $77 R-4$ & $77 \mathrm{R}-4$ & $77 R-4$ & $77 R-4$ & $77 R-4$ & $77 R-4$ & $77 R-4$ & $77 \mathrm{R}-4$ \\
\hline Interval: & $27-$ & $27-$ & $27-$ & $27-$ & $70-$ & $70-$ & $70-$ & $70-$ & $70-$ & $70-$ & $70-$ & $70-$ & $70-$ & $70-$ \\
\hline$(\mathrm{cm}):$ & 35 & 35 & 35 & 35 & 72 & 72 & 72 & 72 & 72 & 72 & 72 & 72 & 72 & 72 \\
\hline Analysis: & 127 & 128 & 129 & 130 & 131 & 132 & 133 & 134 & 135 & 136 & 137 & 138 & 139 & 140 \\
\hline Mineral: & PL & OPX & CPX & PL & CPX & CPX & PL & PL & CPX & CPX & CPX & OPX & CPX & OL \\
\hline $\mathrm{SiO}_{2}$ & 55.31 & 51.03 & 50.57 & 57.40 & 51.48 & 51.43 & 59.05 & 59.79 & 51.47 & 50.72 & 51.34 & 52.42 & 51.03 & 32.94 \\
\hline $\mathrm{TiO}_{2}^{2}$ & - & 0.38 & 0.62 & - & 0.55 & 0.20 & - & - & 0.21 & 0.49 & 0.36 & 0.24 & 0.40 & - \\
\hline $\mathrm{Al}_{2} \mathrm{O}_{3}$ & 27.68 & 0.84 & 2.05 & 27.30 & 1.69 & 0.85 & 25.91 & 25.67 & 0.93 & 1.21 & 1.25 & 0.61 & 1.03 & - \\
\hline $\mathrm{Cr}_{2} \mathrm{O}_{3}$ & - & 0.06 & 0.06 & - & 0.04 & 0.03 & - & - & 0.02 & 0.06 & 0.00 & 0.02 & 0.02 & 0.01 \\
\hline $\mathrm{FeO}$ & 0.23 & 23.62 & 11.82 & 0.18 & 14.48 & 13.36 & 0.17 & 0.13 & 13.64 & 16.22 & 14.72 & 28.38 & 19.57 & 52.35 \\
\hline $\mathrm{MnO}$ & - & 0.70 & 0.36 & - & 0.41 & 0.44 & - & - & 0.50 & 0.55 & 0.50 & 0.82 & 0.62 & 1.01 \\
\hline $\mathrm{NiO}$ & - & 0.03 & 0.03 & - & 0.05 & 0.01 & - & - & 0.02 & 0.03 & 0.00 & 0.01 & 0.00 & 0.03 \\
\hline $\mathrm{MgO}$ & 0.00 & 21.03 & 13.78 & 0.00 & 13.01 & 12.52 & 0.00 & 0.00 & 12.51 & 13.46 & 12.46 & 17.32 & 13.21 & 15.31 \\
\hline $\mathrm{CaO}$ & 8.57 & 1.51 & 20.41 & 7.91 & 18.79 & 20.96 & 7.20 & 6.87 & 20.23 & 15.60 & 19.41 & 2.68 & 15.28 & 0.07 \\
\hline $\mathrm{Na}_{2} \mathrm{O}$ & 6.83 & - & 0.41 & 7.23 & 0.41 & 0.33 & 7.57 & 7.79 & 0.33 & 0.40 & 0.38 & - & 0.30 & - \\
\hline $\mathrm{K}_{2} \mathrm{O}$ & 0.14 & - & - & 0.14 & - & - & 0.08 & 0.11 & - & - & - & - & - & - \\
\hline Sum & 98.75 & 99.19 & 100.11 & 100.16 & 101.02 & 100.13 & 99.97 & 100.38 & 99.86 & 98.74 & 100.44 & 102.50 & 101.46 & 101.57 \\
\hline An & 40.9 & & & 37.7 & & & 34.5 & 32.8 & & & & & & \\
\hline Fo & & & & & & & & & & & & & & 34.0 \\
\hline Wo & & 3.1 & 40.8 & & 39.0 & 42.9 & & & 41.9 & 33.2 & 40.2 & 5.5 & 31.2 & \\
\hline Fn & & 59.5 & 39.3 & & 37.5 & 35.7 & & & 36.0 & 39.9 & 35.9 & 49.2 & 37.6 & \\
\hline Fs & & 37.4 & 18.9 & & 23.5 & 23.5 & & & 22.1 & 26.9 & 23.8 & 45.3 & 31.2 & \\
\hline
\end{tabular}

\begin{tabular}{|c|c|c|c|c|c|c|c|c|c|c|c|c|c|c|}
\hline Core/sect.: & $77 R-4$ & $77 R-4$ & $77 R-4$ & $79 \mathrm{R}-2$ & $79 \mathrm{R}-2$ & 79R-2 & $79 \mathrm{R}-2$ & $80 \mathrm{R}-7$ & $80 \mathrm{R}-7$ & $80 \mathrm{R}-7$ & $80 \mathrm{R}-7$ & $80 \mathrm{R}-7$ & $80 \mathrm{R}-7$ & $80 \mathrm{R}-7$ \\
\hline Interval: & $70-$ & $70-$ & $64-$ & 64. & 64- & 64- & $64-$ & $56-$ & $56-$ & 56- & 56- & 56- & $56-$ & $56-$ \\
\hline (cm): & 72 & 72 & 67 & 67 & 67 & 67 & 67 & 65 & 65 & 65 & 65 & 65 & 65 & 65 \\
\hline Analysis: & 141 & 142 & 143 & 144 & 145 & 146 & 147 & 148 & 149 & 150 & 151 & 152 & 153 & 154 \\
\hline Mineral: & PL & $\mathrm{OL}$ & PL & PL & CPX & CPX & CPX & CPX & PL & $\mathrm{OL}$ & CPX & PL & CPX & $\mathrm{OL}$ \\
\hline $\mathrm{SiO}_{2}$ & 59.59 & 33.22 & 60.10 & 57.29 & 50.97 & 50.27 & 50.42 & 52.01 & 58.99 & 34.30 & 50.19 & 57.56 & 51.55 & 33.89 \\
\hline $\mathrm{TiO}_{2}^{2}$ & - & - & - & - & 0.57 & 0.65 & 0.45 & 0.49 & - & - & 0.45 & - & 0.52 & - \\
\hline $\mathrm{Al}_{2} \mathrm{O}_{3}$ & 25.64 & - & 25.04 & 26.38 & 1.71 & 1.96 & 1.24 & 1.22 & 27.07 & - & 1.40 & 26.78 & 1.57 & - \\
\hline $\mathrm{Cr}_{2} \mathrm{O}_{3}$ & - & 0.00 & - & - & 0.46 & 0.43 & 0.00 & 0.00 & - & 0.00 & 0.00 & 0.02 & 0.00 & 0.00 \\
\hline $\mathrm{FeO}$ & 0.32 & 51.31 & 0.14 & 0.31 & 13.83 & 12.17 & 14.69 & 12.11 & 0.21 & 47.92 & 11.93 & 0.18 & 12.42 & 47.53 \\
\hline $\mathrm{MnO}$ & - & 1.01 & - & - & 0.46 & 0.43 & 0.44 & 0.32 & - & 0.76 & 0.34 & - & 0.39 & 0.72 \\
\hline $\mathrm{NiO}$ & - & 0.04 & - & - & 0.06 & 0.00 & 0.07 & 0.00 & - & 0.06 & 0.02 & - & 0.00 & 0.03 \\
\hline $\mathrm{MgO}$ & 0.00 & 15.08 & 0.00 & 0.03 & 11.49 & 12.39 & 11.85 & 12.82 & 0.00 & 18.21 & 12.97 & 0.04 & 12.88 & 18.52 \\
\hline $\mathrm{CaO}$ & 6.80 & 0.07 & 6.80 & 6.96 & 20.86 & 21.37 & 20.16 & 21.51 & 7.64 & 0.11 & 20.10 & 8.28 & 20.77 & 0.06 \\
\hline $\mathrm{Na}_{2} \mathrm{O}$ & 7.94 & - & 7.80 & 7.84 & 0.45 & 0.44 & 0.41 & 0.39 & 7.50 & - & 2.87 & 7.42 & 0.45 & - \\
\hline $\mathrm{K}_{2} \mathrm{O}$ & 0.10 & - & 0.17 & 0.12 & - & - & - & - & 0.04 & - & - & 0.07 & - & - \\
\hline Sum & 100.40 & 100.74 & 100.08 & 98.93 & 100.41 & 99.67 & 99.73 & 100.86 & 101.46 & 101.38 & 99.78 & 100.33 & 100.54 & 100.72 \\
\hline An & 32.2 & & 32.5 & 33.0 & & & & & 36.0 & & & 38.2 & & \\
\hline Fo & & 34.4 & & & & & & & & 40.4 & & & & 41.0 \\
\hline Wo & & & & & 43.8 & 44.4 & 41.9 & 44.1 & & & 42.4 & & 42.9 & \\
\hline Fn & & & & & 33.6 & 35.8 & 34.3 & 36.5 & & & 38.0 & & 37.0 & \\
\hline Fs & & & & & 22.7 & 19.8 & 23.8 & 19.4 & & & 19.6 & & 20.0 & \\
\hline
\end{tabular}

APPENDIX B

Silicate Mineral Analyses, Hole 735B

\begin{tabular}{lcccc}
\hline Core/sect.: & $80 \mathrm{R}-7$ & $80 \mathrm{R}-7$ & $80 \mathrm{R}-7$ & $80 \mathrm{R}-7$ \\
Interval: & $56-$ & $56-$ & $56-$ & $56-$ \\
$\quad$ (cm): & 65 & 65 & 65 & 65 \\
Analysis: & 155 & 156 & 157 & 158 \\
Mineral: & $\mathrm{OL}$ & $\mathrm{PL}$ & $\mathrm{CPX}$ & $\mathrm{AMPH}$ \\
\hline $\mathrm{SiO}_{2}$ & 34.21 & 58.88 & 52.53 & 42.29 \\
$\mathrm{TiO}_{2}$ & - & - & 0.41 & 2.45 \\
$\mathrm{Al}_{2} \mathrm{O}_{3}$ & - & 26.31 & 1.59 & 12.39 \\
$\mathrm{Cr}_{2} \mathrm{O}_{3}$ & 0.00 & - & 0.01 & 0.01 \\
$\mathrm{FeO}$ & 47.95 & 0.64 & 12.92 & 16.50 \\
$\mathrm{MnO}$ & 0.73 & - & 0.39 & 0.22 \\
$\mathrm{NiO}$ & 0.04 & - & 0.00 & 0.00 \\
$\mathrm{MgO}$ & 18.25 & 0.10 & 13.22 & 11.06 \\
$\mathrm{CaO}$ & 0.07 & 7.48 & 19.22 & 10.63 \\
$\mathrm{Na}{ }_{2} \mathrm{O}$ & - & 7.40 & 0.44 & 3.01 \\
$\mathrm{~K}_{2} \mathrm{O}$ & - & 0.05 & - & 0.19 \\
$\mathrm{Sum}$ & 101.38 & 100.86 & 99.78 & 98.74 \\
\hline $\mathrm{An}$ & & 35.9 & & \\
$\mathrm{Fo}$ & 40.4 & & & \\
Wo & & & 40.3 & \\
$\mathrm{Fn}$ & & & 38.5 & \\
$\mathrm{Fs}$ & & & 21.2 & \\
\hline
\end{tabular}

Note: Analyses are in weight percent. Mineral identification is as follows: $\mathrm{PL}=$ plagioclase, $\mathrm{OL}=$ olivine, $\mathrm{CPX}=$ clinopyroxene, $\mathrm{OPX}=$ orthopyroxene, $\mathrm{PIG}$ $=$ pigeonite, $\mathrm{AMPH}=$ amphibole. Some minerals are designated as $\mathrm{P}=$ porphyroclast, or $\mathrm{N}=$ neoblast. End-member proportions of An (anorthite) for PL, Fo (forsterite) for OL, and Wo-En-Fs for pyroxenes were computed from structural formulae. Mineral analyses are listed in order of acquisition for each sample, to indicate mineral associations. Summary compositions of intergrown pyroxenes are listed in Table 2 of the text. 